


\section{DISCLAIMER}

This report was prepared as an account of work sponsored by an agency of the United States Government. Neither the United States Government nor any agency Thereof, nor any of their employees, makes any warranty, express or implied, or assumes any legal liability or responsibility for the accuracy, completeness, or usefulness of any information, apparatus, product, or process disclosed, or represents that its use would not infringe privately owned rights. Reference herein to any specific commercial product, process, or service by trade name, trademark, manufacturer, or otherwise does not necessarily constitute or imply its endorsement, recommendation, or favoring by the United States Government or any agency thereof. The views and opinions of authors expressed herein do not necessarily state or reflect those of the United States Government or any agency thereof. 


\section{DISCLAIMER}

Portions of this document may be illegible in electronic image products. Images are produced from the best available original document. 


\section{DISCLAIMER}

"This book was prepared as an account of work sponsored by an agency of the United States Government. Neither the United States Government nor any agency therenf, nor any of their employees, makes any warranty, express or implied, or assumes any legal liability or responsibility for the accuracy, completeness, or usefulness of any information, apparatus, product, or process disclosed, or represents that its usc would not infringe privately owned rights. Reference herein to any specific commercial product, process, or service by trade name, trademark, manufacturer, or otherwise, does not necessarily constitute or imply its endorsement, recommendation, or favoring by the United States Government or any agency thereof. The views and opinions of authors expressed herein do not necessarily state or reflect those of the United States Government or any agency thereof."

This report has been reproduced directly from the best available copy.

Available from the National Technical Information Service, U. S. Department of Commerce, Springfield, Virginia 22161.

Price: Printed Copy A04

Microfiche A01 


\title{
DOWNSTREAM COMPONENT CORROSION IN COAL-FIRED MHD POWER PLANTS
}

\section{TOPICAL REPORT}

(INTERIM REPORT)

Principal Investigator:

M. K. White

\author{
Prepared by: \\ The University of Tennessee Space Institute \\ Energy Conversion Division \\ Tullahoma, Tennessee 37388 \\ June, 1980 \\ PREPARED FOR THE UNITED STATES \\ DEPARTMENT OF ENERGY
}

Under Contract No. DE-AC02-79ET10815 


\section{ABSTRACT}

Results are given to date of corrosion probe studies conducted to evaluate the nature and severity of degradation of boiler and superheater materials in coal-fired MHD power generation systems. Tests were conducted with two air or nitrogen cooled probes in Cell III of the UTSI MHD facility. One probe had carbon steel samples subjected to metal temperatures of from $547 \mathrm{~K}$ to $719 \mathrm{~K}$ and reducing $(S R=0.85$ ) gas conditions to simulate boiler tube conditions. The exposure time to date on these samples is 240 minutes. The other probe had samples nf carbon utcel, cliiumlum-molybdenim steels and stainless steels subjected to temperatures ranging from $811 \mathrm{~K}$ to $914 \mathrm{~K}$ with oxidizing ( $S R=1.15)$ gas conditions. The total run time on these samples was 70 minutes.

The boller probe samples were found to undergo predominantly pitting type corrosion beneath a deposit of ash/seed material having approximately $34 \% \mathrm{~K}_{2} \mathrm{CO}_{3}$ and $16.4 \% \quad \mathrm{~K}_{2} \mathrm{SO}_{4}$. Weight loss rates varied from about 1.5 $x 10^{-4} \mathrm{gm} / \mathrm{hr}-\mathrm{cm}^{2}$ at the cool end of the probe to about $5.5 \times 10^{-4}$ $\mathrm{gm} / \mathrm{hr}-\mathrm{cm}^{2}$ at the hot end. This loss is attributed primarily to sulfidation by hydrogen sulfide.

Resistance to scaling of superheater materials increased progressively with the degree of alloying. Attack appeared to be in the form of surface scales containing mixtures of oxides and is attributed to either gaseous oxidation or to the presence of complex potassium trisulfates. 


\section{CONTENTS}

Abstract ......................... ii

I. Introduction ........................ vii

II. Background ........................ 1

III. Equipment and Procedures . . . . . . . . . . . 8

IV. Results . . . . . . . . . . . . . . . . 11

A. Boiler Tube Simulation .............. 11

B. Superheater Tube Simulation . . . . . . . . 36

v. Discussion . . . . . . . . . . . 54

A. Boller Corrosion ............... 54

B. Superheater Corrosion . . . . . . . . . 56

C. Future Testing . . . . . . . . . . . 57

VI. Conclusions and Summary . . . . . . . . . . . 57

References . . . . . . . . . . . . . . . . . 58 


\section{FIGURES}

1. Behavior of Various Alloys Under Hot-Corrosion Attack by $\mathrm{K}_{2} \mathrm{SO}_{4}$

in $70 h$ Tests . . . . . . . . . . . . . . . . 4

2. Behavior of Various Alloys Under Hot-Corrosion Attack by $\mathrm{K}_{2} \mathrm{SO}_{4}$ in $250 h$ Tests .................... 5

3. Intruaive Prohe . . , . . . . . . . . . . . . . . . . 8

4. Cel1 III Downstream Component Test Facility . . . . . . . . . 9

5. Reducing Atmosphere Probe Installed at Cross-Over Duct Port . . . 10

6. Materials, Placement and Temperatures for the Superheater Probe . . 12

7. Superheater Probe Installed after the Secondary Combustor of Cell III . . . . . . . . . . . . . . . . 13

8. Cleaned Boiler Probe Appearance after Run TP41-02 . . . . . . 16

9. Boiler Probe Middle Sample Surface after Run TP41-02, 62.5X . . . 17

10. Boiler Probe Appearance after Run TP41-03 . . . . . . . . 18

11. Boiler Probe Appearance after Run TP41-04 . . . . . . . . . . 19

12. Pitted Surface of Boiler Probe Sample 5 after Run TP41-04, 50X . . 20

13. SEM Photograph and EDX Spectrum at a Point Inward of the Deposit

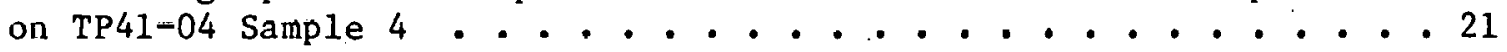

14. SEM Photograph and EDX Spectrum of the Inner Deposit of TP41-04 Sample 4 . . . . . . . . . . . . . . . 22

15. SEM Photograph and EDX Spectrum of the Intermediate Deposit of TP41-n4 Sample $4 . . . . . . . . . . . . . .23$

16. SEM Photograph (236X) and EDX Spectra at Locations Across the Deposit Thickness of TP41-04 Sample 4 . . . . . . . . . . 24

17. Boiler Probc Appearance aftér Run TP41-05 . . . . . . . . 26

18. Cross-Section of Boller Probe Deposit on TP41-05 Sample 4, 62.5X . . 27

19. Boiler Probe Front Surface Appearance after Run TP41-05, 62.5X . . . 28

20. Boiler Probe Back Surface Appearance after Run TP41-05, 62.5X . : 29 
21. Boiler Probe Appearance after Run TP41-07 . . . . . . . 30

22. Corroded Front Surface of Boiler Probe Samples after Run

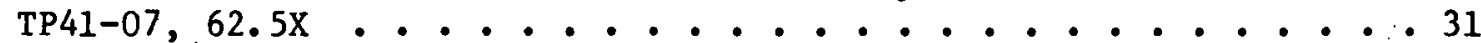

23. Corroded Back Surface of Boller Probe Samples after Run

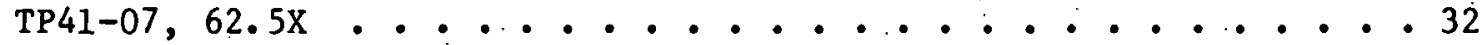

24. Area of TP41-07 Sample 4, Largely Free of Corrosion Pits . . . . 33

25. Heavily Corroded Area of TP41-07 Sample 4 . . . . . . . . : 34

26. Boiler Probe Appearance after Run TP41-13 . . . . . . . . 35

27. Boiler Probe Appearance after Run TP41-14 . . . . . . . . . 37

28. Boiler Probe Surface Degradation After TP41-14 and 240 Minutes

Accumulated Exposure, 62.5X . . . . . . . . . . . 38

29. Weight Loss from the Boiler Probe Samples . . . . . . . . . 39

30. Superheater Probe Appearance after Run TP41-13 . . . . . . 40

31. Cross-Section Views of Deposits on Superheater Probe Spacer 1

After TP41-13,62.5X .................. 41

32. Superheater Probe Appearance after Run TP41-14 . . . . . . . 43

33. Deposits' on Superheater Spacer 1 after TP41-14,62.5X . . . . . 44

34. Inner Part of Front Deposit on Superheater Probe Space 1

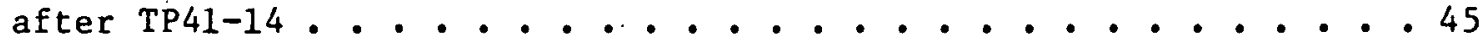

35. Outer Part of Front Deposit on Superheater Probe Spacer 1

after TP41-14..................... . . 46

36. Cross-Section of Ash/Seed Deposit on Superheater Probe Spacer 1

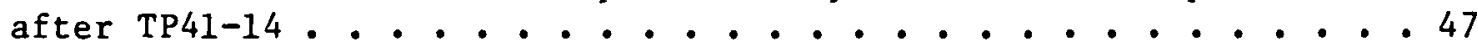

37. Outer and Inner Deposits on Back of Superheater Probe Spacer 1

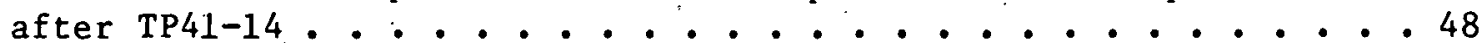

38. Cleaned Superheater Probe Samples after Run TP41-14 . . . . . . 49

39. Surface Scale on Carbon Steel Superheater Probe Sample after

Run TP41-14.................... . . 50

40. Micrograph Showing Scale on Back of Croloy 9 Superheater Probe

Sample after TP41-14, 500X . . . . . . . . . . . . 50

41. Scale on Front of Superheater Probe Samples after TP41-14 . . . 51

42. Front Surface of 310 Stainless Steel Superheater Probe Sample after TP41-14,62.5X .................. 52 
43. Scale Buildup on Superheater Probe Samples . . . . . . . . . 53

44. Equilibrium Sulfur Forms at Various Temperatures . . . . . . . 54

45. Equilibrium Diagram of the $\mathrm{Fe}-\mathrm{CO}-\mathrm{CO}_{2}$ System . . . . . . . 55

\section{TABLES}

I. Average Corrosion Rates of Metals in Seeded Flue Gas in $100 \mathrm{~h}$

Exposure . . . . . . . . . . . . . . . . . . 6

II. Relative Ranking of Some Selected Alloys in Decreasing Order of Resistance to Hot Corrosion Attack . . . . . . . . . . 6

III. Ranking of Metallic Materials in Order of Decreasing Resistance to Reducing Simulated Boiler Tube Conditions ........... . 7

IV. Nominal Cell III Test Conditions for Test Plan 41 . . . . . . . 14

V. Runs and Exposure Times for Corrosion Probes . . . . . . . . 15 


\section{INTRODUCTION}

The contents of this report represent the results to date of a project aimed at evaluating the oxidation, corrosion, erosion and other stability characteristics of metallic materials in the steam generation section of coal-fired MHD power plants. Simulation of tube surface conditions in boilers and superheaters was achieved by using air or nitrogen cooled intrusive probes inserted into the flow stream of the UTSI Cell III coalfired test facility. Ring samples of various alloys were exposed to reducing and oxidizing flue gases containing potassium seed compounds and flyash.

These tests were conducted in the fourth quarter, 1979. Continued testing using the same probes and samples to obtain longer accumulated exposure time is planned for mid-1980. In addition, probes will be located at key positions in the Coal-Fired Flow Facility (CFFF) downstream for studying corrosion and ash deposition and chemistry. Initially these probes will be in the radiant furnace and secondary combustor sections of the flow train. It is because of the on-going testing that this report is submitted as an "Interim" Topical Report. 


\section{BACKGROUND}

The primary factor limiting operating temperatures in conventional steam generators and gas turbines is metals corrosion by compounds of potassium, sodium, sulfur and vanadium. Each component of these systems has its own distinctive problem depending upon the temperature range involved. Boiler tubes have experienced problems associated with the formation of corrosive liquid alkali pyrosulfates in the $625-725 \mathrm{~K}$ range. Superheaters and preheaters are subject to liquid complex alkali sulfate corrosion at metal temperatures in the range of 875 to $1025 \mathrm{~K}$. The situation of low temperature air heaters is quite different in that the flue gas temperature must be kept above the dewpoint for condensation of sulfuric acid, $365-425 \mathrm{~K}$, depending upon the concentration of $\mathrm{SO}_{3}, \mathrm{H}_{2} \mathrm{O}$, and other constituents. Gas turbines operate in still another corrosion regime. The corrosive agent in this case is liquid alkali sulfates in the 1025 to $1250 \mathrm{~K}$ range. Fluxing of protective oxides can also occur by deposition of acidic oxides such as $\mathrm{V}_{2} \mathrm{O}_{5}$ when low grade fuels containing vanadium are burned in gas turbines.

Alkali seeding to increase the ionization of the combustion gas in the MHD process can increase the alkali content of the effluent from ten to twenty times. Higher combustion temperatures and different stoichiometries and residence times may also be expected to affect the nature and severity of corrosive processes significantly. Removal of sulfur from the flue gas by the potassium is expected to practically eliminate problems of sulfuric acid attack on low temperature air heater tubes and water wall surfaces. Therefore, the problems relevant to MHD steam generators are expected to be attack of boiler. tubes by gaseous sulfidation and liquid phases in the system $\mathrm{K}_{2} \mathrm{CO}_{3}-\mathrm{KOH}-\mathrm{K}_{2} \mathrm{SO}_{4}-\mathrm{SO}_{3}$ and of superheater and intermediate temperature air heater tubes by solid or liquid phases in the system $\mathrm{K}_{2} \mathrm{SO}_{4}-\mathrm{Fe}_{2} \mathrm{O}_{3}-\mathrm{SO}_{3}$, specifically $\mathrm{K}_{3} \mathrm{Fe}\left(\mathrm{SO}_{4}\right)_{3}$.

In addition to their corrosive effects, ash/seed deposits on heat transfer surfaces can seriously affect heat transfer rates, resulting in such conditions as reduced stean temperature, increased flue gas temperature, and shifting of the slag/ash/seed deposition zones further downstream. Excessive deposits clog the gas passageways, increase pressure drop, and decrease the mass flow of combustion products.

Fused slag on furnace walls results from condensation of the vapor on cool surfaces and physical transport of particulate matter to "sticky" surfaces. The composition of the fused slag may vary at different locations in the furnace because of differences in. condensation temperatures and mass transport.

Corrosion of conventional furnace wall tubes has been found to occur under a porous slag layer that containe sulfate or sulfite in the portion nearest the wall.1 Under most circumstances, these materials are solids 
at the operating temperatures. However, liquid pyrosulfates can occur at high $\mathrm{SO}_{3}$ concentrations $(1000-1500 \mathrm{ppm})$, with consequent faster corrosion rates due to reaction with or fluxing of the iron oxide scale. While the flue gas contains only $10-15 \mathrm{ppm} \mathrm{SO}_{3}$, the much higher concentrations needed for formation of liquid phases may result from catalytic oxidation of $\mathrm{SO}_{2}$ in the outer ash layer.

The mechanism of corrosion by potassium pyrosulfate may be as
follows:

1) Conversion of alkalies to $\mathrm{K}_{2} \mathrm{SO}_{4}$ either in the bulk gas or on exposed metal surfaces.

2) Oxidation of $\mathrm{SO}_{2}$ in the bulk flue gas to $\mathrm{SO}_{3}$ on catalytically active surfaces.

3) Formation of $\mathrm{K}_{2} \mathrm{~S}_{2} \mathrm{O}_{7}$ by reaction of the sulfate with $\mathrm{SO}_{3}$.

4) Reaction of the pyrosulfate with oxide films on metal surfaces, typically

$$
\begin{aligned}
& 3 \mathrm{~K}_{2} \mathrm{~S}_{2} \mathrm{O}_{7}+\mathrm{Fe}_{2} \mathrm{O}_{3} \rightarrow 3 \mathrm{~K}_{2} \mathrm{SO}_{4}+\mathrm{Fe}_{2}\left(\mathrm{SO}_{4}\right)_{3} \\
& \text { or } 4 \mathrm{~K}_{2} \mathrm{~S}_{2} \mathrm{O}_{7}+\mathrm{Fe}_{3} \mathrm{O}_{4} \rightarrow 4 \mathrm{~K}_{2} \mathrm{SO}_{4}+\mathrm{FeSO}_{4}+\mathrm{Fe}_{2}\left(\mathrm{SO}_{4}\right)_{3} \\
& \text { or } 3 \mathrm{~K}_{2} \mathrm{~S}_{2} \mathrm{O}_{7}+\mathrm{Fe}_{2} \mathrm{O}_{3} \rightarrow 2 \mathrm{~K}_{3} \mathrm{Fe}\left(\mathrm{SO}_{4}\right)_{3} \\
& \text { which decomposes according to } \\
& 2 \mathrm{~K}_{3} \mathrm{Fe}\left(\mathrm{SO}_{4}\right)_{3} \rightarrow 3 \mathrm{~K}_{2} \mathrm{SO}_{4}+\mathrm{Fe}_{2} \mathrm{O}_{3}+3 \mathrm{SO}_{3} .
\end{aligned}
$$

5) Further oxidation of the metal to replace the surface oxide film.

Another possible furnace wall corrosive system is $\mathrm{K}_{2} \mathrm{CO}_{3}-\mathrm{KOH}$, which can melt at $640 \mathrm{~K}$ or lower, depending upon the amount and type of impurities present, whereas, liquid phase development for pure $\mathrm{K}_{2} \mathrm{CO}_{3}$ occurs at $1075 \mathrm{~K} .3^{3}$ Little attention has been directed toward alkali carbonate corrosion. It is supposed, however, that degradation occurs by a combination of oxidation and oxide removal hy fluxing.

In MHD coal-fired systems, both $\mathrm{K}_{2} \mathrm{SO}_{4}$ and $\mathrm{K}_{2} \mathrm{Co}_{3}$ exist simultaneously in the radiant furnace section prior to secondary combustion. How the two components may interact to cause corrosion is unknown. The system is made very complex by the presence of other constituents such as $\mathrm{H}_{2} \mathrm{~S}, \mathrm{~K}_{2} \mathrm{~S}, \mathrm{SO}_{3}, \mathrm{KOH}$, and flyash.

Hot corrosion of superheaters, reheaters and intermediate temperature a1r heaters is a function of metal temperature and reaches a maximum, in conventional steam generators, between 950 and $1000 \mathrm{~K} .4$ This corrosion is found on the upstream side of the tubes under strongly-bonded sintered slag-type deposits. The outer deposits are porous and allow gas permeation, although they may be hard and brittle. The intermediate deposits have been found to be of a chalky texture and contain higher concentrations of 
alkalies and sulfur than found in the original coal. Complex alkali sulfates, which have been shown in laboratory studies to corrode nost superheater alloys when molten, have also been found in the intermediate layer. As in the case of formation of pyrosulfates on furnace walls, the high $\mathrm{SO}_{3}$ required to form the complex alkali-metal sulfate is believed to result from catalytic oxidation of $\mathrm{SO}_{2}$ in the outer ash layer. Although the reactions between complex alkali-metal sulfates and tube materials is not fully understood, one theory that has been tentatively accepted is shown below: 5

$$
3 \mathrm{~K}_{2} \mathrm{SO}_{4}+\mathrm{Fe}_{2} \mathrm{O}_{3}+3 \mathrm{SO}_{3}+2 \mathrm{~K}_{3} \mathrm{Fe}\left(\mathrm{SO}_{4}\right)_{3}
$$

and

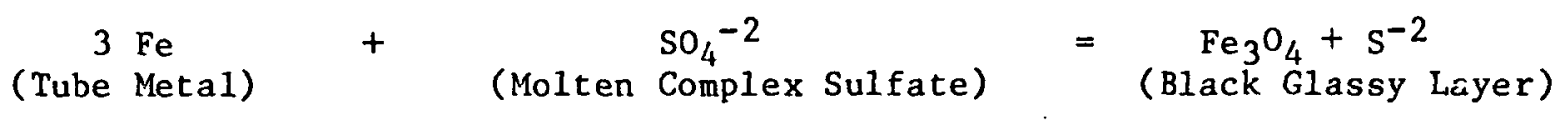

In the first equation the iron oxide may be either in the flyash or be the oxide scale on the tube. The complex sulfate formed further reacts with the iron from the tube surface to form "enamel" deposits found on corroded tubes. Thus, the complex trisulfate is both an intermediate reaction product and a corrosive agent.

The exact mechanisms by which tube corrosion occurs varies from alloy to alloy and is affected by temperature, gas and deposit impurities, activity gradients, etc. In general, it is agreed that oxidation, sulfidation, and sulfidation-plus-oxidation are the principal phenomena which degrade, materials. These reactions may be accompanied by dissolution (fluxing) of a protective oxide layer by liquid phases, as well as formation of low temperature metal sulfide liquids.

Procedures taken to minimize both furnace wall and superheater tube corrosion are 6,7 .

1) use of low excess air in combustion to limit the amount of $\mathrm{SO}_{3}$ available to form pyrosulfates or complex trisulfates,

2) periodic removal of deposits, thereby preventing the buildup of high concentrations of $\mathrm{SO}_{3}$,

3) careful selection and grinding of the coal,

4) use of stainless steel tubes or stainless shields on tubes at vulnerable locations, and

5) the injection of additives such as magnesium and calcium oxides onto the tube surfaces to form harmless sulfates.

Tests were run at the U.S. Bureau of Mines at Bruceton in 1971 to determine the corrosive effects of high alkali concentrations in coal-fired MHD systems. 8 The combustion gas, either seeded or unseeded, flowed through a heat exchanger consisting of air cooled tubes of a variety of metals and alloys. The gas side surface temperature was controlled between 700 and $1090 \mathrm{~K}$. The degree of corrosion was determined from the thinning of 
the tube walls, and the nature of the attack by metallographic examination of the tube metal and by analysis of the deposits Eound on tubes. In a 100hour test, tube materials exposed to the seeded flue gas were more severely attacked than those exposed to the non-seeded flue gas. Haynes 25, a cobalt-base alloy, was satisfactory for use at the $1090 \mathrm{~K}$ wall temperature and $1645 \mathrm{~K}$ seeded flue gas temperature. No corrosion was experienced by 310 , 316 , and 446 stainless steel at the $865 \mathrm{~K}$ wall temperature and $1425 \mathrm{~K}$ gas temperature. Carbon steel and Croloy 5 were attacked at a wall temperature of $700 \mathrm{~K}$ and flue gas temperature of $1255 \mathrm{~K}$.

In British simulation tests, 9 small air-cooled tubular superheater metal specinens ( $1.1 \mathrm{~cm}$ diameter) were exposed to flue gases from a residual oil burner with added 0.01 atomic percent $K$ and also sodium and vanadium impurities. Additionally, $50_{2}$ was added tu give a 2000 ppm concentracion. The excess oxygen was maintained at $1 \%$ by volume. Figure 1 shnws the

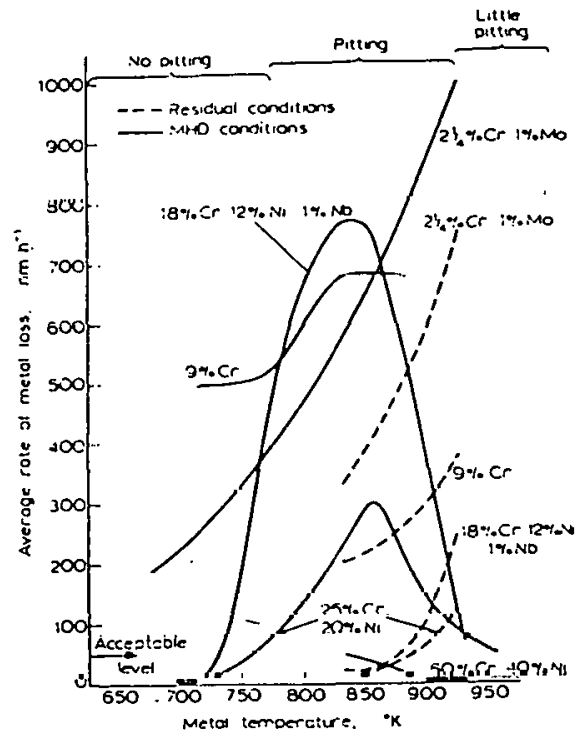

\section{Figure 1. Behavior of Various Alloys Under Hot-Corrosion Attack by $\mathrm{K}_{2} \mathrm{SO}_{4}$ in $70 \mathrm{~h}$ Tests ${ }^{9}$}

results of 70 hour exposures on a number of materials at temperatures between 673 and 923K. Corrosion rates were found to be much worse under MHD conditions than for residual fuel oil flue gases containing no potassium. The maximum corrosion occurred within the 750-900k range, presumably due to a liquid phase, No peaks were shown hy the low chromium. steols, Only one steel, $60 \mathrm{Cr} / 40 \mathrm{Ni}$ was found to have a corrosion penetration rate of less than $50 \mathrm{~nm} / \mathrm{hr}$, which was judged to be an acceptable level. The average corrosion rates for 250 hour tests were lower than for the 70 hour tests and the rate for 1000 hours was, in a few cases, still less. Figure 2 shows the results of the 250 hour tests in which the corrosion peaks appeared at slightly higher temperatures.

According to their acceptance criteria either carbon steel or $21 / 4 \mathrm{Cr}-$ 1 Mo could be used up to 650K. Type 18Cr-12Ni-1Nb (Type $347 \mathrm{SS}$ ) could be used up to $725 \mathrm{~K}$. Up to $920 \mathrm{~K}, 60 \mathrm{Cr}-40 \mathrm{Ni}$ and $65 \mathrm{Ni}-35 \mathrm{Cr}$ were found to be 


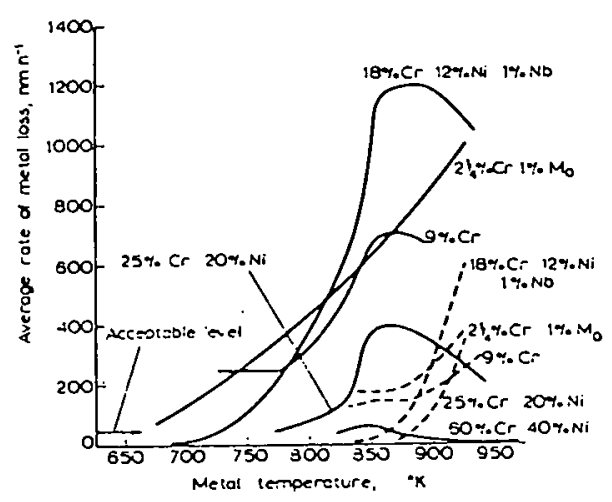

\section{Figure 2. Behavior of Various Alloys Under Hot-Corrosion Attack by $\mathrm{K}_{2} \mathrm{SO}_{4}$ in $250 \mathrm{~h}$ Tests ${ }^{9}$}

sufficiently corrosion resistant. But $25 \mathrm{Cr}-20 \mathrm{Ni}$, which corroded twice as fast as these, was found to be just marginally acceptable.

Above $900 \mathrm{~K}$, tests of 100 hours duration were performed by the same British investigators using. hollow cylindrical specimens mounted horizontally across a vertical electric furnace tube in which flowed heated flue gas derived from burning benzene-thiophene air mixtures.10. Their "standard seed" mixture containing the sodium and vanadium impurities and added $\mathrm{SO}_{2}$ was used as in the lower temperature tests. Table I gives the results. Kanthal (23Cr-6Al) performed best with $60 \mathrm{Cr}-40 \mathrm{Ni}$ being only slightly inferior. Investigators at the Australian Electric Research Laboratory (AERL) experienced severe corrosion of several stainless steels and high-temperature nickel alloys at metal temperatures above $1145 \mathrm{~K}$ and higher gas temperatures with simulated seed and ash-laden MHD combustion gases.11 These metal temperatures are above those considered for MHD steam generator or air heater components. The corrosion mechanism was explained as a sulfidation process, in which liquid alkali sulfates react with the tube metals to forin sulfides.

A literature evaluation of potential alloys and coatings for MHD superheater tubes was conducted by the National Bureau of Standards in 1977.12 Table II shows the relative ranking of some selected alloys in decreasing order of resistance to hot corrosion attack. INCO alloy 814, with the nominal composition, 35Cr-15.6Fe-3.5Al - 0.35Ti-0.6Mn-0.2Si-bal Ni, has been reported to show significantly less attack under hot corrosion conditions than INCO 671.13 Amorig their conclusions on resistance of alloys to hot corrosion attack are the following:

1) Resistance increases with and is very sensitive to chromium content, the protection being provided by the chromium oxide film that is formed.

2) Alloys that depend on an $\mathrm{Al}_{2} \mathrm{O}_{3}$ film for oxidation protection should be avoided.

3) Alloys high in tungsten and molybdenum added as carbide formers should be avoided, as the carbides act as nucleation centers for surface corrosion pitting. 
TABLE I

Average Corrosion Rates of Metals in Seeded Flue Gas in $100 \mathrm{~h}$. Exposure $\left(\mathrm{nmh}^{-1}\right)^{10}$

\begin{tabular}{|c|c|c|c|c|c|c|c|}
\hline \multicolumn{2}{|c|}{ Metal } & \multicolumn{6}{|c|}{ Temperature $\left({ }^{\circ} \mathrm{K}\right)$} \\
\hline Name & Composition & 925 & 975 & 1025 & 1075 & 1175 & 1275 \\
\hline Nimonic 90 & $(20 \mathrm{Cr}-58 \mathrm{Ni}-18 \mathrm{Co})$ & - & - & - & - & - & 750 \\
\hline Nimonic 105 & $(15 \mathrm{Cr}-45 \mathrm{Al}-5 \mathrm{Mo}-20 \mathrm{Co})$ & - & 1050 & - & 2100 & 500 & - \\
\hline - & $(60 \mathrm{Cr}-40 \mathrm{Ni})$ & 188 & - & 250 & - & 375 & 288 \\
\hline Kanthal & $(23 \mathrm{Cr}-6 \mathrm{Al})$ & 250 & - & 188 & - & 63 & 188 \\
\hline Stellite 12 & $(29 \mathrm{Cr}-59 \mathrm{Co}-9 \mathrm{~W})$ & 95 & - & - & 213 & - & - \\
\hline
\end{tabular}

TABLE II

1 Relative Ranking of Some Selected Alloys in Decreasing Order of Resistance to Họt Corrosion Attack ${ }^{12}$

Inconel 671

Haynes 25

FSX -418

310 S.S.

U 500

316 S.S.
446 S.S.

WI -52

IN -713

Croloy $9(9 \mathrm{Cr}-1$ Mo Stee1)

Croloy 2-1/4 (2-1/4Cr-1Mo Steel)

Croloy $5(5 \mathrm{Cr}-.55 \mathrm{Mo}$ Steel $)$ 
4) The combination of chloride and sulfate corrosion is worse than either alone.

Another generally agreed upon conclusion is that disproportionately high nickel content relative to chromium content is undesirable due to nickel's low sulfidation resistance.

A series of corrosion experiments has been performed at the Argonne National Laboratory in which a number of metallic alloys were exposed to controlled oxygen and sulfur partial pressures and temperatures from 719 to $811 \mathrm{~K}$, prototypic of superheaters and boiler tubes. 14 In addition to exposure of bare alloys for gaseous corrosion evaluation, specimens coated with a 50:50 mixture of $\mathrm{K}_{2} \mathrm{SO}_{4}$ and Montana Rosebud flyash by plasma spraying were tested to study resistance to hot corrosion. Table III shows

\section{TABLE III}

Ranking of Metallic Materials in Order of Decreasing Resistance to Reducing Simulated Boiler Tube Conditions ${ }^{14}$

\begin{tabular}{|l|l|}
\hline $723 \mathrm{~K}\left(842^{\circ} \mathrm{F}\right)$ & $811 \mathrm{~K}\left(1000^{\circ} \mathrm{F}\right)$ \\
\hline $310 \mathrm{SS}$ & $310 \mathrm{SS}$ \\
$316 \mathrm{SS}$ & $304 \mathrm{SS}$ \\
$304 \mathrm{SS}$ & $316 \mathrm{SS}$ \\
A1loy 800 & A1loy 800 \\
A1loy 750 & Alloy 750 \\
A1loy 600 & Croloy 9 \\
Croloy 9 & Croloy 2 1/4 \\
Croloy 2 1/4 & Alloy 600 \\
1020 Carbon Steel & 1020 Carbon Steel \\
\hline
\end{tabular}

ranking of the alloys after 200 hours of exposure at 723 and $811 \mathrm{~K}$ with reducing conditions. Little difference was found between specimens having ash/seed coatings and those without. The resistance to corrosion generally corresponded to increasing chromium content, the low chromium alloys suffering extensive sulfide scale formation. Only minimal corrosion was found after 500 hours of exposure to oxidizing conditions at $811 \mathrm{~K}$.

It is important to note that none of the corrosion tests and evaluations described previously adequately simulate actual coal-fired MHD boiler tube and superheater conditions in terms of the complex chemical and physical characteristics of the flow stream and deposits of slag, seed and ash on heat transfer surfaces. This points out the importance of the experiments to be described in this report. However, it is to be expected that, even with materials testing under actual MHD conditions, wide variation in results is likely in different facilities and under differing operating conditions. Therefore, it is imperative that, in all such tests, the run conditions be as close as possible to expected baseline conditions for a fullscale plant and that all aspects of the actual conditions be thoroughly documented. 


\section{EQUIPMENT AND PROCEDURES}

The corrosion tests were performed using two gas cooled probes, one of which is shown in Figure 3. These consisted essentially of two concentric cylinders with either air or nitrogen flowing for cooling inside the inner

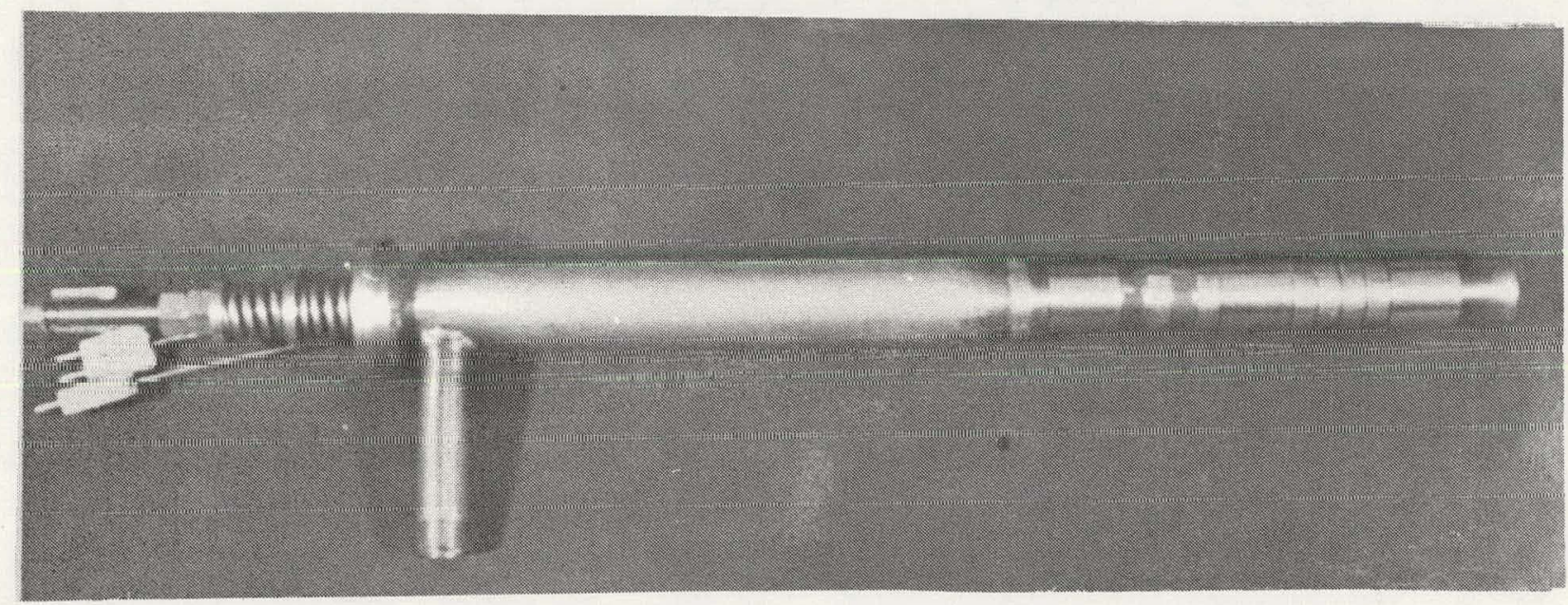

Figure 3. Intrusive Probe

one and in the annulus between the two. An assembly of cylindrical specimens, each $3.81 \mathrm{~cm}(1.5 \mathrm{in}) 0 . \mathrm{D}$. and either $1.27 \mathrm{~cm}(0.5 \mathrm{in})$ or $3.81 \mathrm{~cm}$ ( $1.5 \mathrm{in}$ ) long, constituted part of the outer cylinder. This sample assembly was sealed against gas leakage by stainless steel o-rings.

Three thermocouples were located inside the wall of the sample section, one at the middle and one at each end, for temperature measurement and control. The thermocouple signals were processed by the computer with temperatures displayed on the video monitors during the tests. Temperatures were controlled by manually adjusting the gas coolant flow to each probe with a control valve to give the desired temperature at the middle of the test section within $\pm 10 \mathrm{~K}$.

As stated earlier, the two test conditions were designed to simulate expected bofler and superheater tube conditions. For the boiler tube simulation, one probe having an assembly of seven specimens of 1030 carbon steel, each $3.81 \mathrm{~cm}$ ( $1.5 \mathrm{in}$ ) long, was located in a reducing atmosphere (stoichiometry 0.85) in the cross-over duct of Cell III at one of the ports previously used for gas sampling, as shown Figures 4 and 5 . The control 


\section{CELL III DOWNSTREAM COMPONENT TEST FACILITY}

Secondary Oxidant !njectors

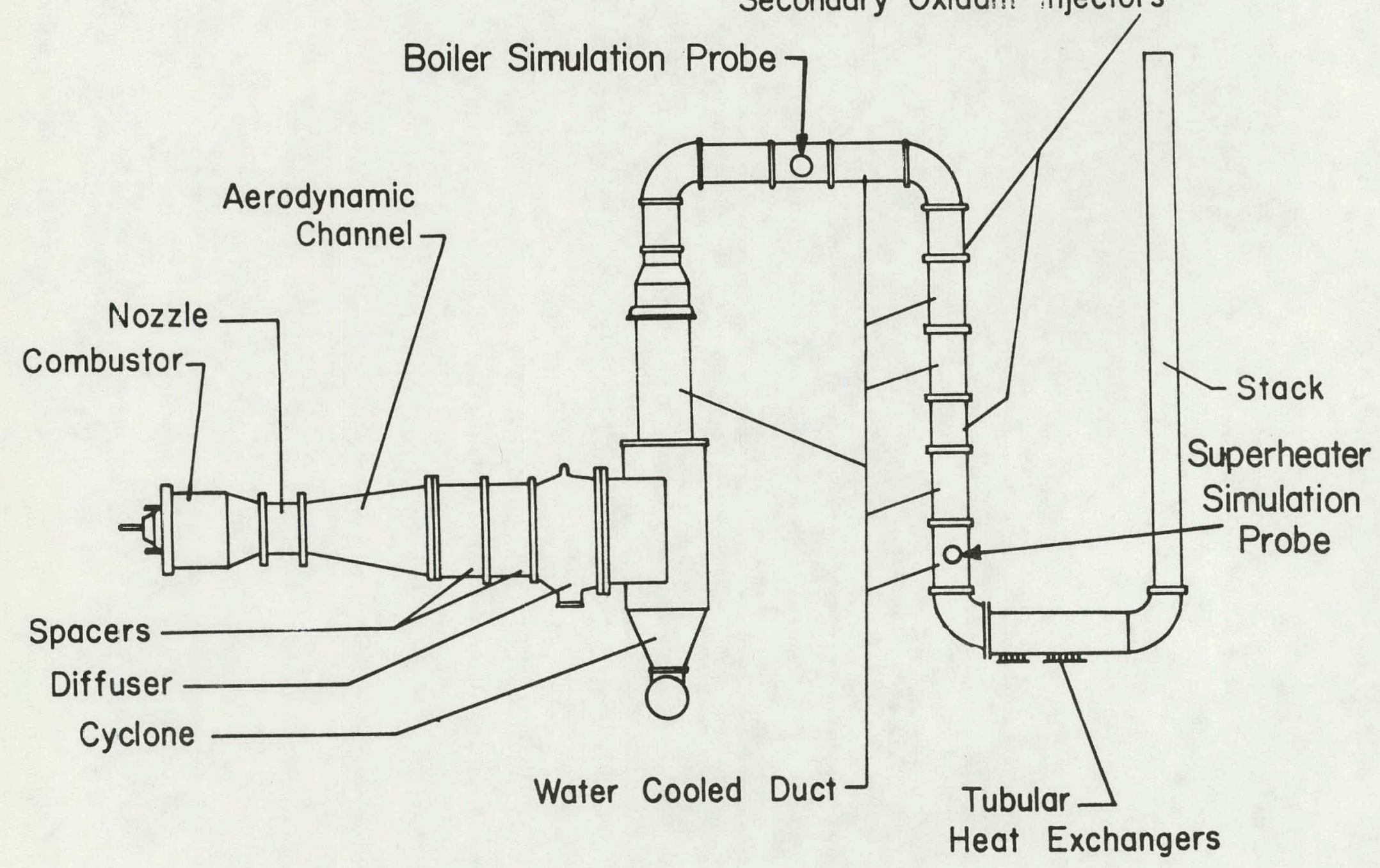

Figure 4. Cell III Downstream Component Test Facility 


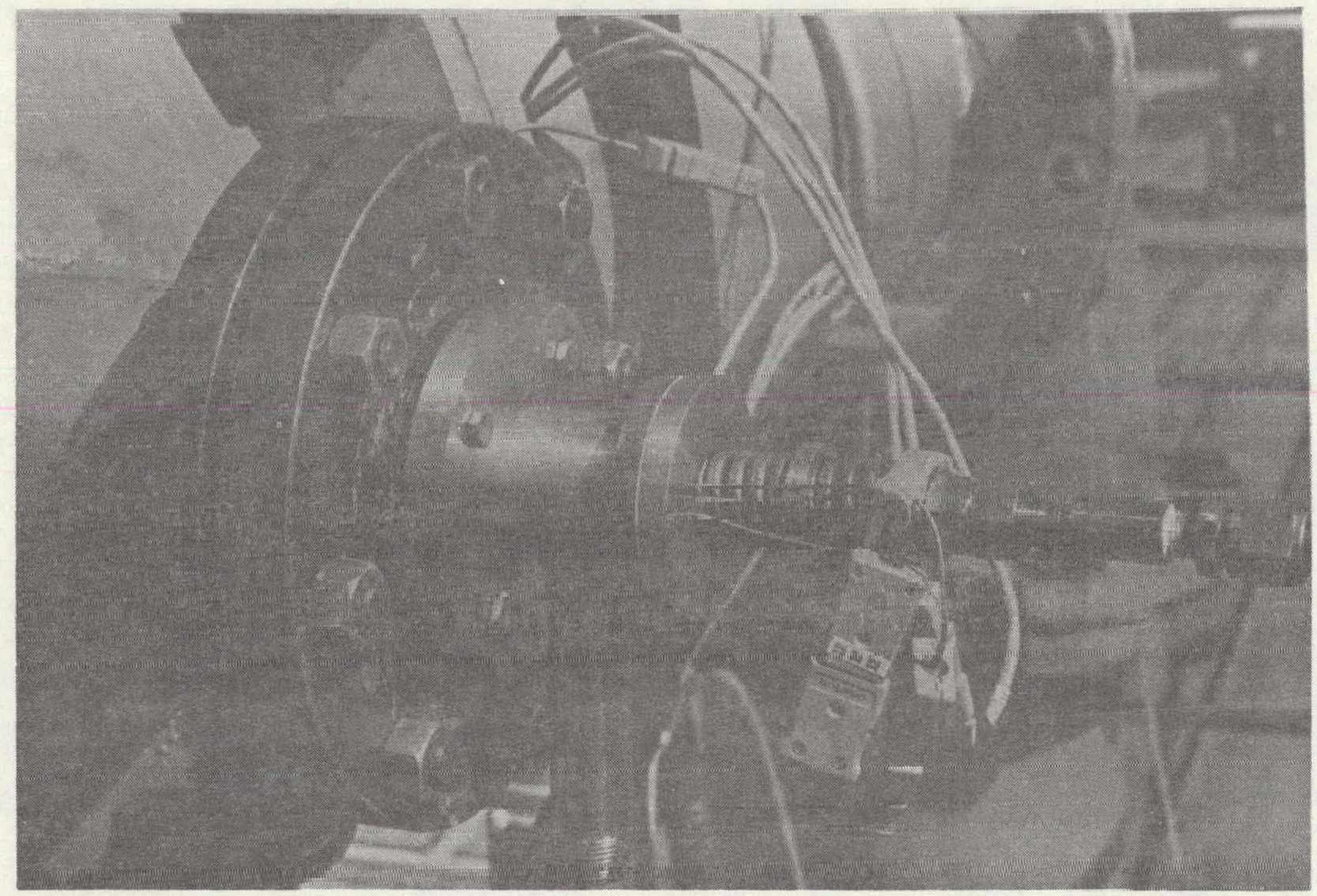

Figure 5. Reducing Atmosphere Probe Installed at Cross-Over Duct Port 
temperature for this probe was $644 \mathrm{~K}\left(700^{\circ} \mathrm{F}\right)$ with the combustion gas temperature continuously increasing during a test to a maximum of about $1075 \mathrm{~K}\left(1472^{\circ} \mathrm{F}\right)$. For the superheater tube simulation, the other probe had an assembly of eight different steel alloy samples, each $1.27 \mathrm{~cm}(0.5$ in) long plus three $3.81 \mathrm{~cm}$ ( $1.5 \mathrm{in}$ ) long spacers of 304 stainless steel at the ends and middle of the test section. Figure 6 shows the materials used and their placement on the probe. This probe was located in the oxidizing atmosphere (stoichiometry 1.15) in the downcomer between the secondary combustor and the heat exchanger, as shown in Figures 4 and 7 . The control temperature was $866 \mathrm{~K}\left(1100^{\circ} \mathrm{F}\right)$ with a maximum gas temperature of about $1025 \mathrm{~K}\left(1382^{\circ} \mathrm{F}\right)$

Prior to the initial installation, microphotographs were taken of the samples for each probe. For the superheater probe, the initial weight of each sample was also measured. Due to lack of availability at the time of a precision analytical balance with sufficient capacity to weigh the $3.81 \mathrm{~cm}$ (1.5 in) long samples, the boiler probe samples were not weighed until after Run 3, at which point only about 12 minutes of run time had been accumulated.

\section{RESULTS}

The nominal operating conditions under which Cell III was run during these tests are given in Table IV. Table V lists the runs during which the probes were exposed, along with the run times and test conditions. The boiler probe was tested during nine attempted runs, four of which were aborted due to operational difficulties with no steady-state run time. The total accumulated run time to date on the boiler probe is 240 minutes. The superheater probe was tested during Runs 13 and 14 for a total run time of 70 minutes. It is noted that in considering all run times quoted, additional time on kerosene fuel was experienced including 25 minutes for facility shakedown and several additional minutes to stabilize the combustion process each time a run was attempted.

After each run the probe was removed and photos taken with deposits in place. In most cases the deposits were photographed microscopically and then removed and stored. The samples were disassembled, cleaned by washing with water and then acetone, and then weighed and examined microscopically. Optical, SEM and EDX techniques were used. In addition, cheriical analysis was made of one deposit sample from each probe. After Run 13 the probes were left assembled with deposits intact except for replacing the first spacer of the superheater probe. Both probes were stored in dessicated bags between runs.

\section{A. BOILER TUBE SIMULATION}

During the initial shakedown run of TP41, kerosene was fired for about 25 minutes and the middle sample of the boiler probe reached a temperature of about 550K. Run TP41-01 was stopped after about seven minutes with about two minutes on coal due to a false alarm condition, the probe control temperature again reaching about 550K. TP41-02 ran a total of about 22 minutes on kerosene with two unsuccessful attempts to get coal flow. The 


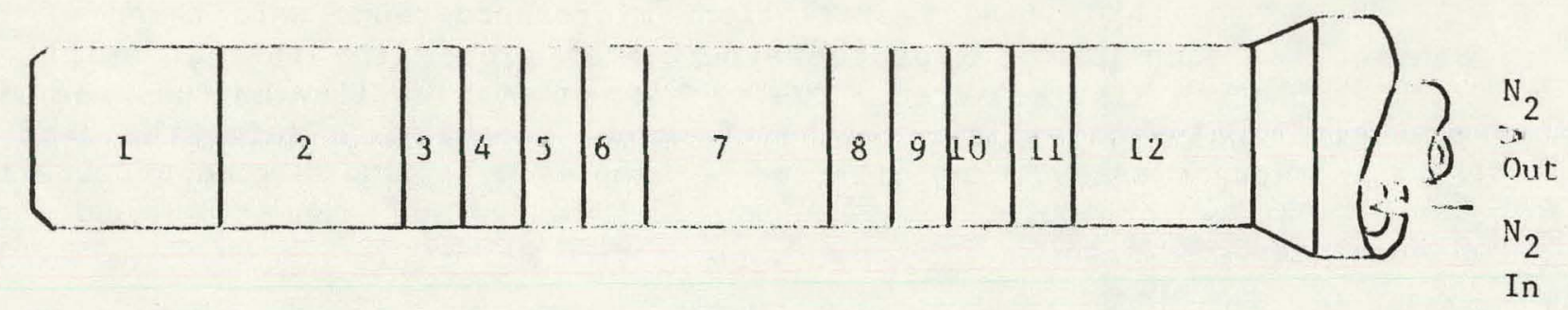

\begin{tabular}{|c|c|c|c|}
\hline Part No. & Desci Ipliun & Marerial & Mid-Yoint l'emperat \\
\hline 1 & End Cap & 3.16L S.S. & - \\
\hline 2 & Spacer 1 & 304 S.S. & $912 \mathrm{~K}(1182 \mathrm{~F})$ \\
\hline 3 & Sample 1 & 1030 carbon steel & $908 \mathrm{~K}(1175 \mathrm{~F})$ \\
\hline 4 & Sample 2 & $1 / 2$ Croloy & $898 \mathrm{~K}(1157 \mathrm{~F})$ \\
\hline 5 & Sample 3 & $2-1 / 4$ Croloy & $888 \mathrm{~K}(1139 \mathrm{~F})$ \\
\hline 6 & Sample 4 & 304 S.S. & $878 \mathrm{~K}(1121 \mathrm{~F})$ \\
\hline 7 & Spacer 2 & 304 S.S. & $866 \mathrm{~K}(1100 \mathrm{~F})$ \\
\hline 8 & Sample 5 & 9 Croloy & $849 \mathrm{~K}(1069 \mathrm{~F})$ \\
\hline 9 & Sample 6 & 310 S.S. & $844 \mathrm{~K}(1060 \mathrm{~F})$ \\
\hline 10 & Sample 7 & S. S. & $840 \mathrm{~K}(1053 \mathrm{~F})$ \\
\hline 11 & Sample 8 & S. S. & $835 \mathrm{~K}(1044 \mathrm{~F})$ \\
\hline 12 & Spacer 3 & S. S. & $815 \mathrm{~K}(1007 \mathrm{~F})$ \\
\hline
\end{tabular}

Figure 6. Materials, Placement and Temperatures for the Superheater Probe 


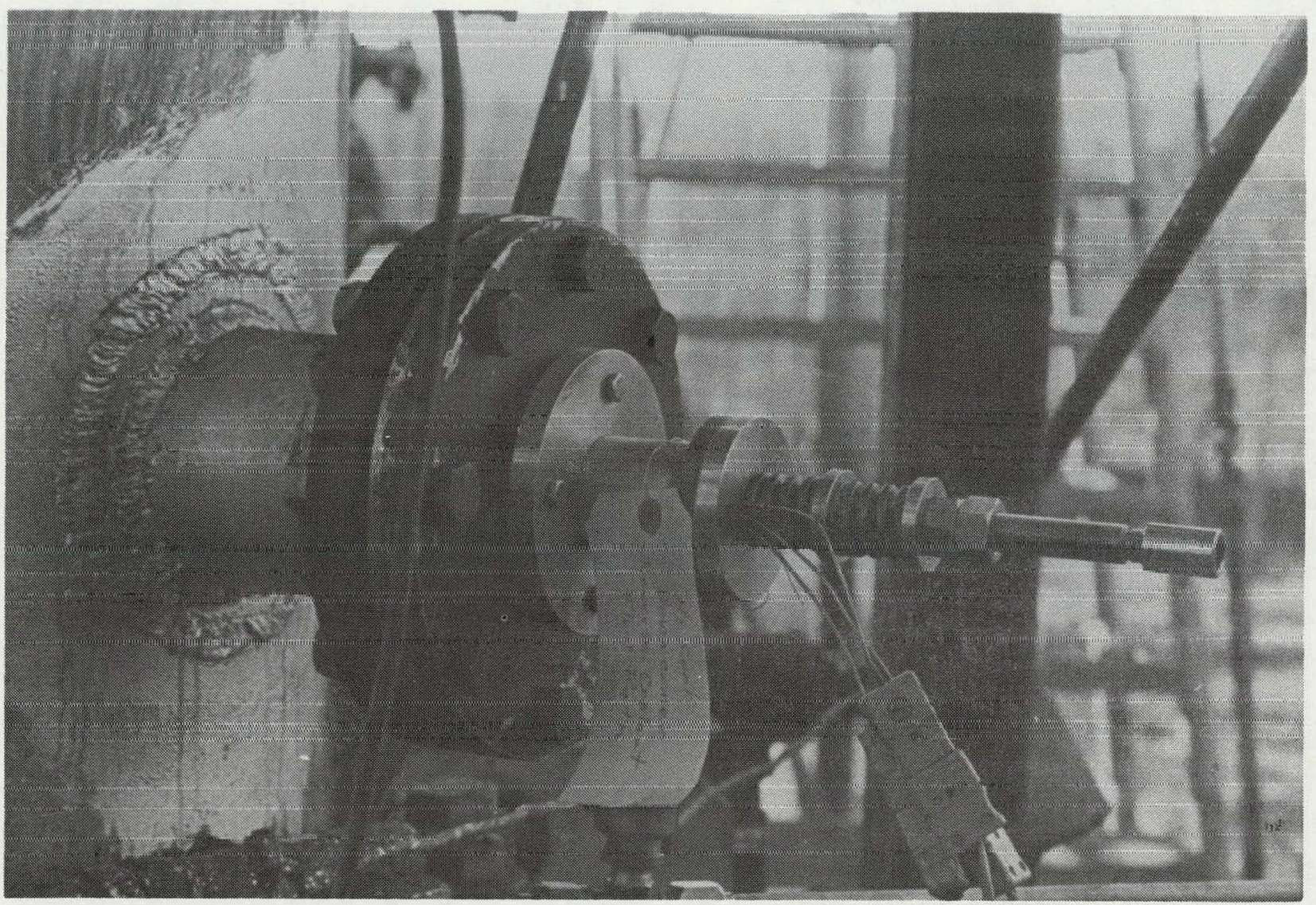

Figure 7. Superheater Probe Installed after the Secondary Combustor of Cell III

\section{UTSI}


Nominal Cell III Test Conditions for Test Plan 41

Coal: Illinois No. 6

Coal Proximate Analysis (as received): $8.90 \%$ Moisture, $11.40 \%$ Ash, $38.00 \%$ Volitile Matter, $41.70 \%$ Fixed Carbon

Coal U1timate Analysis (as received): 5.40\% Hydrogen, 62.40 Carbon, $1.20 \%$ Nitrogen, $16.30 \%$ Oxygen, $3.30 \%$ Sulfur, $11.40 \%$ Ash

Ash Analysis: $\quad 40.86 \% \mathrm{SiO}_{2}, 19.05 \% \mathrm{Al}_{2} \mathrm{O}_{3}, 22.01 \% \mathrm{Fe}_{2} \mathrm{O}_{3}, 0.89 \%$

$\mathrm{TiO}_{2}, 0.12 \% \mathrm{P}_{2} \mathrm{O}_{5}, 5.33 \% \mathrm{CaO}, 1.68 \% \mathrm{MgO}, 0.39 \% \mathrm{Na}_{2} \mathrm{O}, 2.07 \%$

$\mathrm{K}_{2} \mathrm{O}, 7.40 \% \mathrm{SO}_{3}$

Seed: $\mathrm{K}_{2} \mathrm{CO}_{3}$

Vitiation Oxidant Preheat Fuel: Kerosene

Primary Combustion Temperature: 2500K

Primary Oxidant Temperature: Ambient

Primary Stoichiometry: 0.85

Secondary Combustion Temperature: 1600K

Secondary Oxidant Temperature: Ambient

Secondary Stolchiometry: 1.15

Flow Rates ( $1 \mathrm{~b} / \mathrm{sec})$

Coal: 0.45

Primary $\mathrm{O}_{2}: 0.8$

Primary $\mathrm{N}_{2}: 0.3$

Secondary $\mathrm{O}_{2}: 0.25$

Secondary $\mathrm{N}_{2}$ : 0.6 (except for run condition 2 in which flow

rates were varied from 0 to 0.2 to $0.41 \mathrm{~b} / \mathrm{sec}$ )

Seeding Level: $17 \%$ by weight

Calcium added to coal in some tests to determine behavior in tieing up sulfur. 
TABLE V

Runs and Exposure Times for Corrosion Probes

\begin{tabular}{|c|c|c|c|c|c|c|c|}
\hline Run & $\begin{array}{l}\text { Total } \\
\text { Duration }\end{array}$ & $\begin{array}{l}\text { Time } \\
\text { on Coal }\end{array}$ & $\begin{array}{l}\text { Steady-State } \\
\text { Probe Exposure Time }\end{array}$ & $\begin{array}{l}\text { Boiler Probe } \\
\text { Cumulative Time }\end{array}$ & $\begin{array}{c}\text { Superheater Probe } \\
\text { Cumulative Time }\end{array}$ & $\begin{array}{c}\text { Samples } \\
\text { Weighed } \\
\text { After }\end{array}$ & $\begin{array}{c}\text { Percent } \\
\mathrm{CaCO}_{3} \\
\text { Added }\end{array}$ \\
\hline & $(\min )$ & (min) & (min) & & & & \\
\hline $\begin{array}{l}\text { Facility } \\
\text { Shakedown }\end{array}$ & 25 & 0 & 0 & 0 & 0 & No & 0 \\
\hline 1 & 7 & 2 & 0 & 0 & 0 & No & 0 \\
\hline 2 & 22 & 0 & 0 & 0 & 0 & Yes & 0 \\
\hline 3 & 19 & 12 & 0 & 0 & 0 & Yes & 0 \\
\hline 4 & 79 & 75 & 73 & 73 & 0 & Yes & 0 \\
\hline 5 & $?$ & 57 & 45 & 118 & 0 & Yes & 0 \\
\hline 6 & $?$ & 2 & 0 & 118 & 0 & No & 0 \\
\hline 7 & 63 & 60 & 52 & 170 & 0 & Yes & 0 \\
\hline 13 & 36 & 32 & 26 & 196 & 26 & No & 6.25 \\
\hline 14 & $?$ & 54 & 44 & 240 & 70 & Yes & 12.5 \\
\hline
\end{tabular}


probe was pulled out and found to be covered with a wet, black substance that was mostly kerosene residue. Figure 8 shows the appearance of the samples after cleaning. All samples were blackened and showed evidence of some corrosive attack, the severity increasing toward the hot end, i.e.,

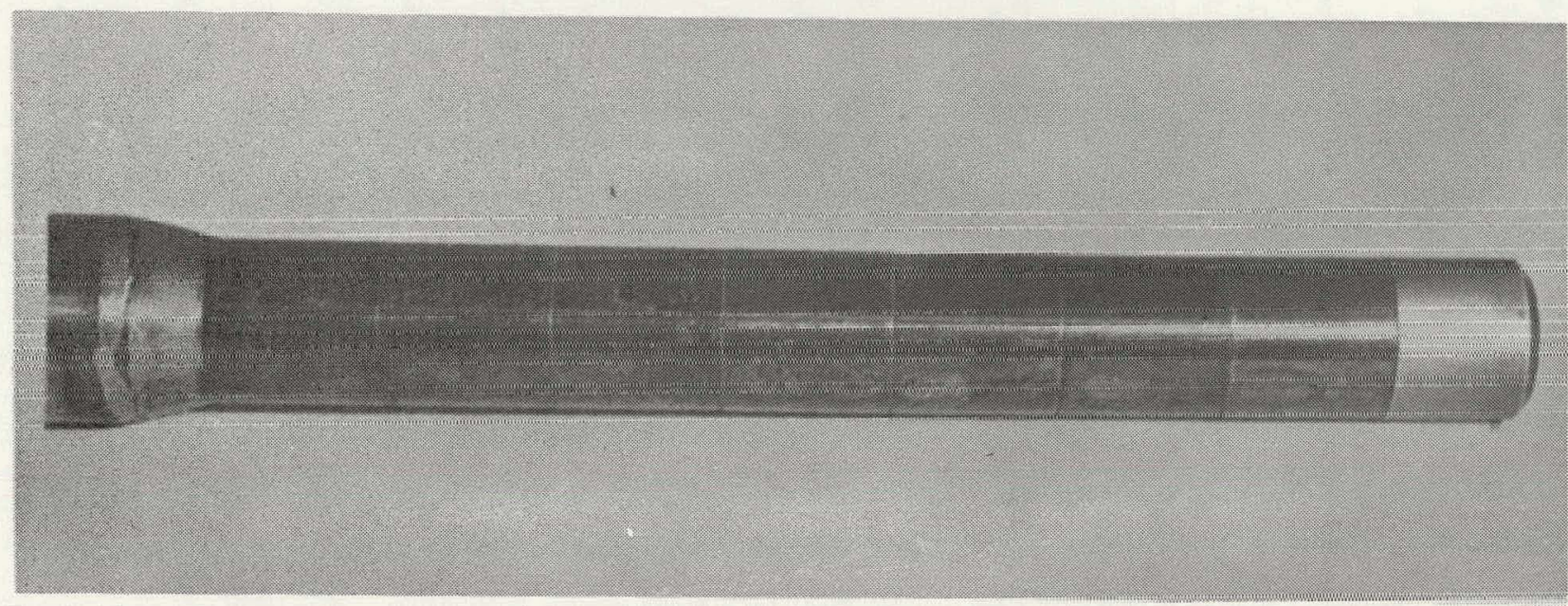

Figure 8. Cleaned Bo1ler Probe Appearance after Run TP41-02

toward the flange end of the probe. The underside of the samples showed rings where liquid had apparently stood in drops. Figure 9 shows the surface of the middle sample (sample 4) at the upstream and downstream faces.

After about 19 minutes of run time on TP41-03 with about 12 minutes on coal, the system was shut down due to a faulty thermocouple indicating an overheated water condition. The probe was removed and its appearance was as shown in Figure 10. It was found during all of the tests that the deposits on the back side of the probe were very loose and in most cases fell off the probe before or during removal. The deposits on the front of samples 3-7, by contrast, were very hard and adherent, like stone or a refractory ceramic. A rather strong $\mathrm{H}_{2} \mathrm{~S}$ smell was present. The material underlying the fallen-off deposit on the rear was uniformly black. The deposits on the front appeared gray on the surface. Through the thickness, the front deposits appeared grayish-white with some red or brown. After removing the deposits by chipping and cleaning the samples with organic solvents, the probe was disassembled and each sample welghed with a beam type analytical balance. Some weight loss was evident.

TP41-04 was run for a Lotal of about 79 minutcs and terminated before the desired 120 minutes due to running low on nitrogen. Operating conditions were good. The probe was left in the duct overnight and when removed the next day was found to have absorbed considerable moisture from the atmosphere via a hydration process. Its appearance being shown in Figure 11. The color was much darker than on the previous run when the probe was removed immediately. All of the outer deposit had fallen off the back side and off all of the end cap, sample 1 and half of sample 2. During the time when the probe was being photographed and examined, the underlying material left on these areas was observed to absorb molsture until liquid deposit was running off the probe. The outer deposits elsewhere on the 


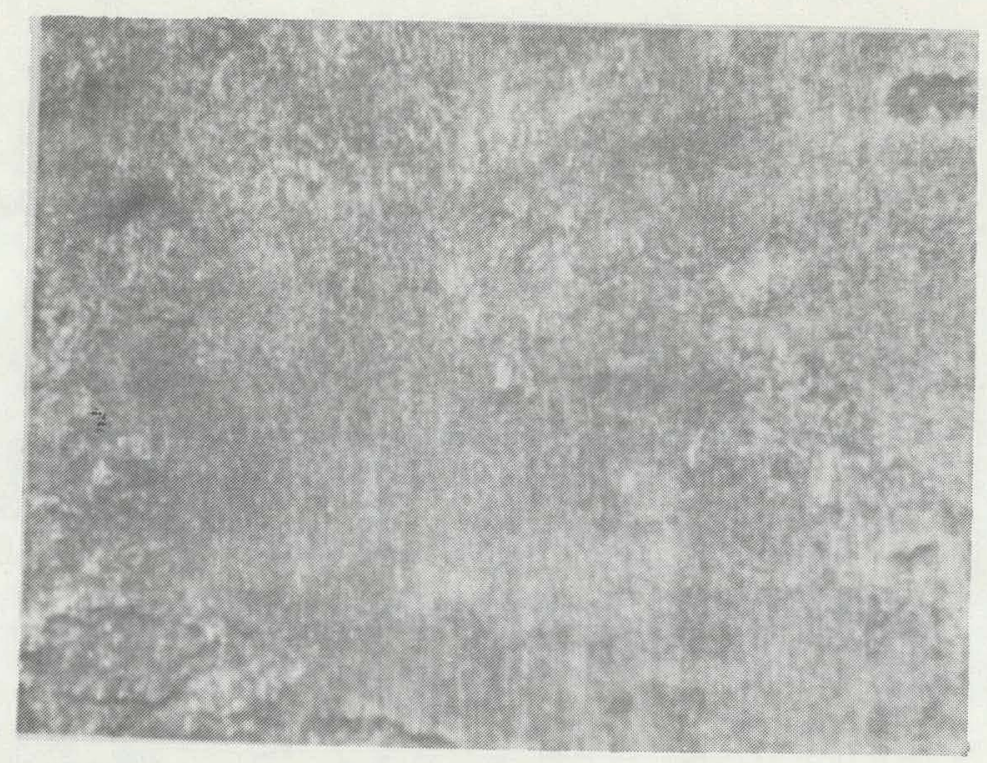

a) Front

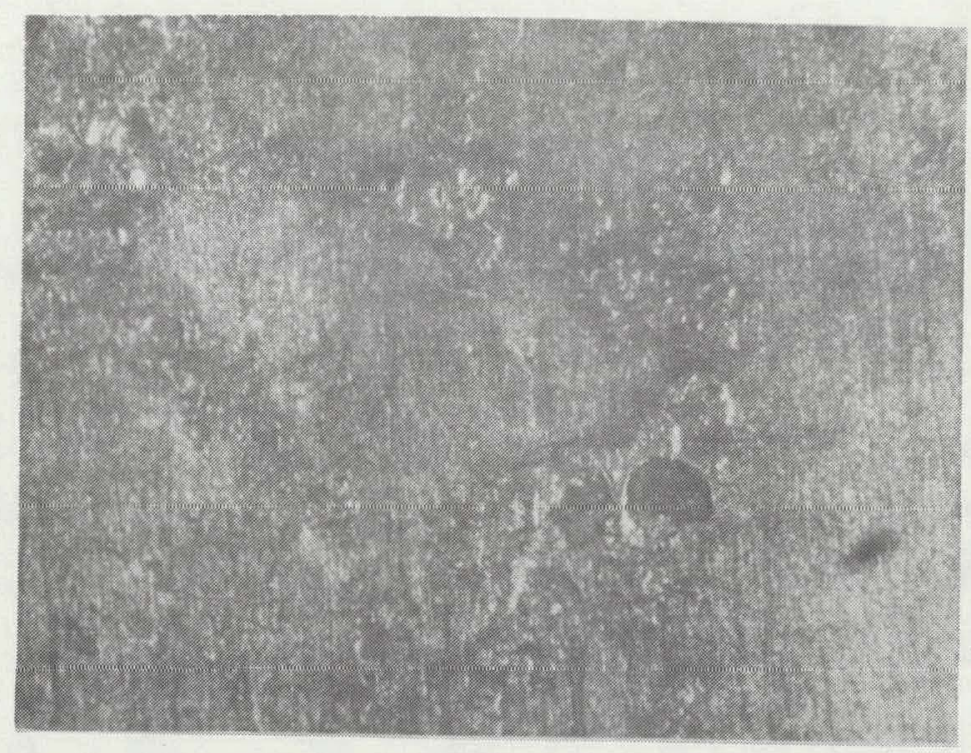

b) Back

Figure 9. Boiler Probe Middle Sample Surface after Run TP41-02, 62.5X 


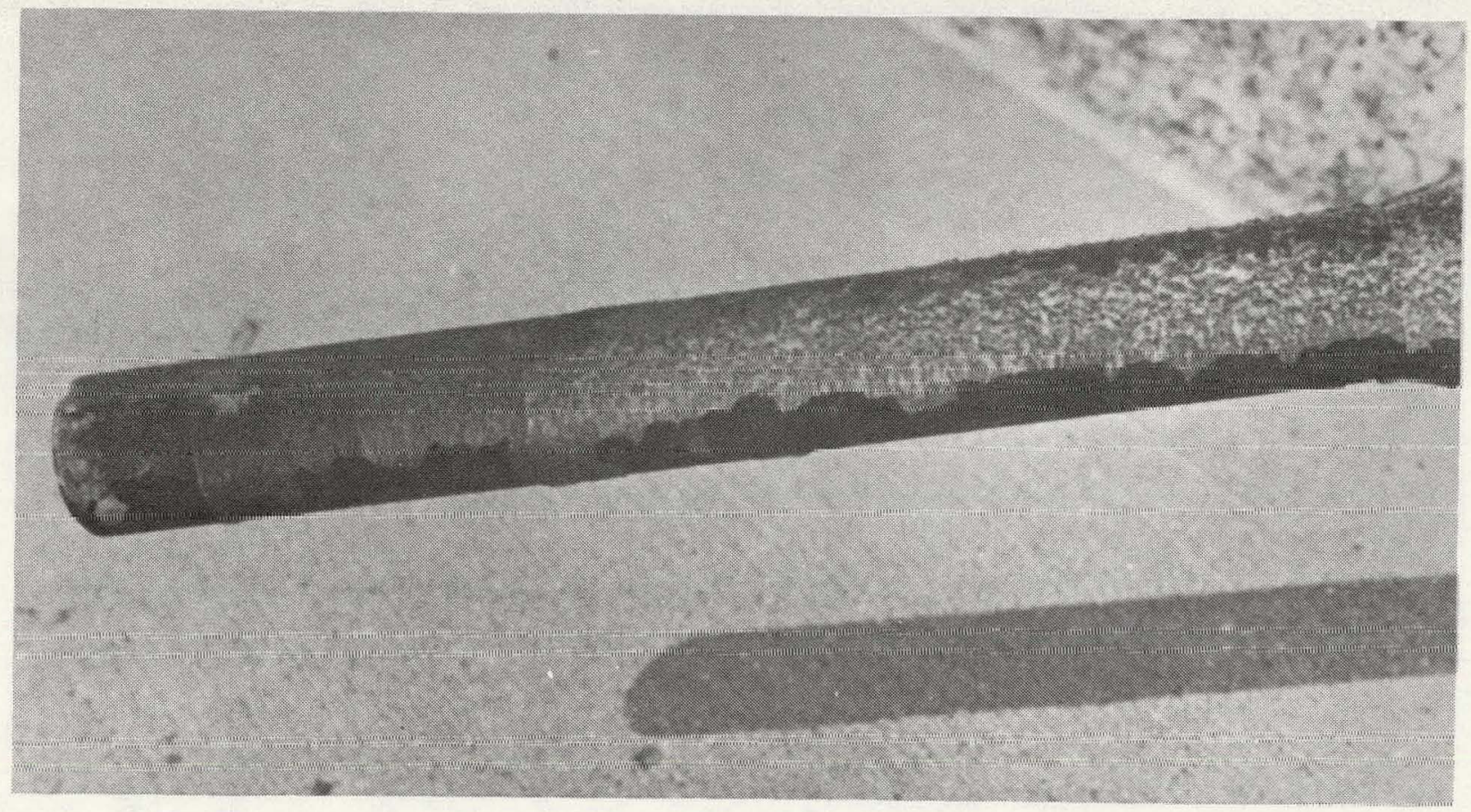

a) Front

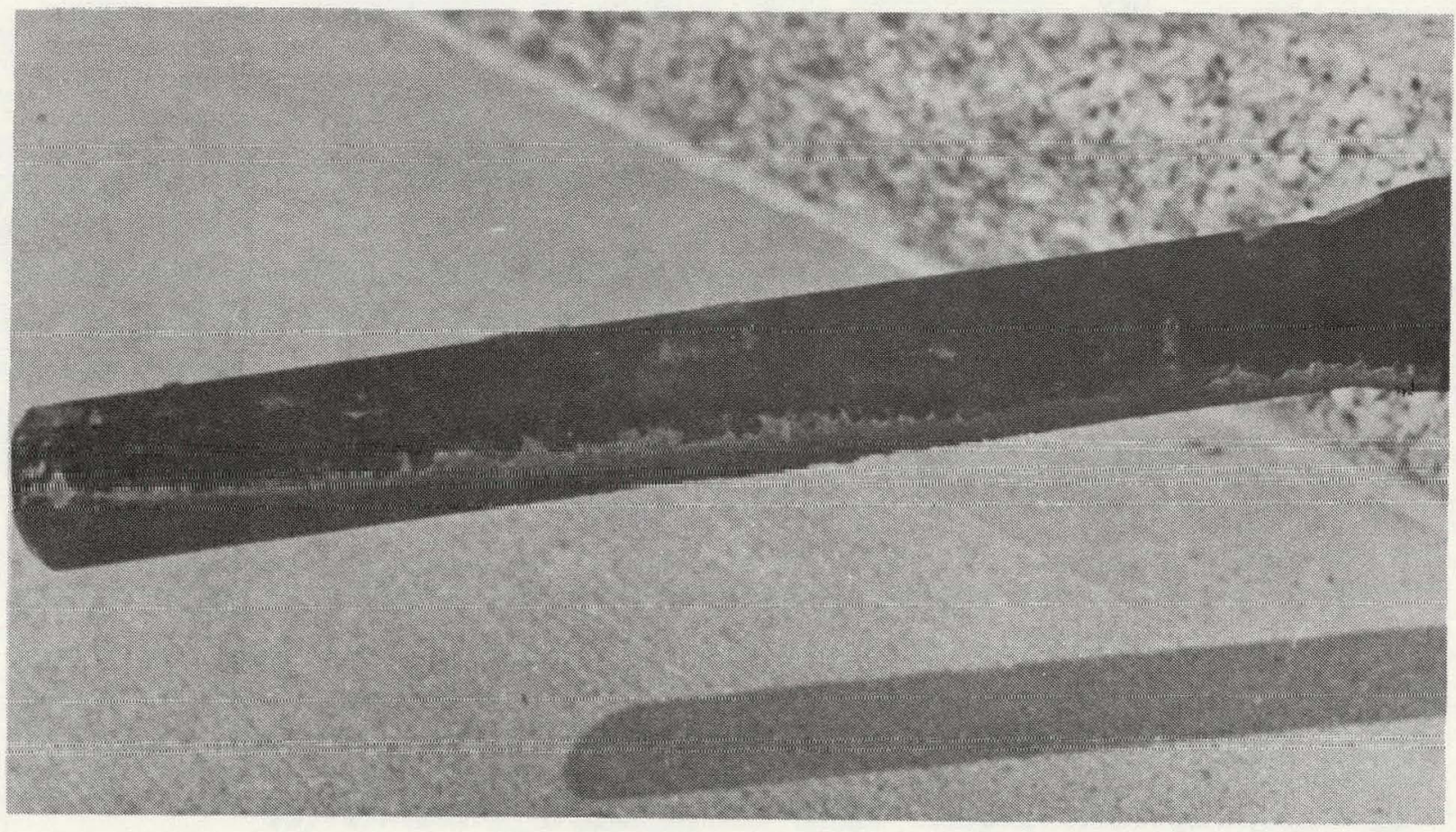

b) Back

Figure 10. Boiler Probe Appearance after Run TP41-03 


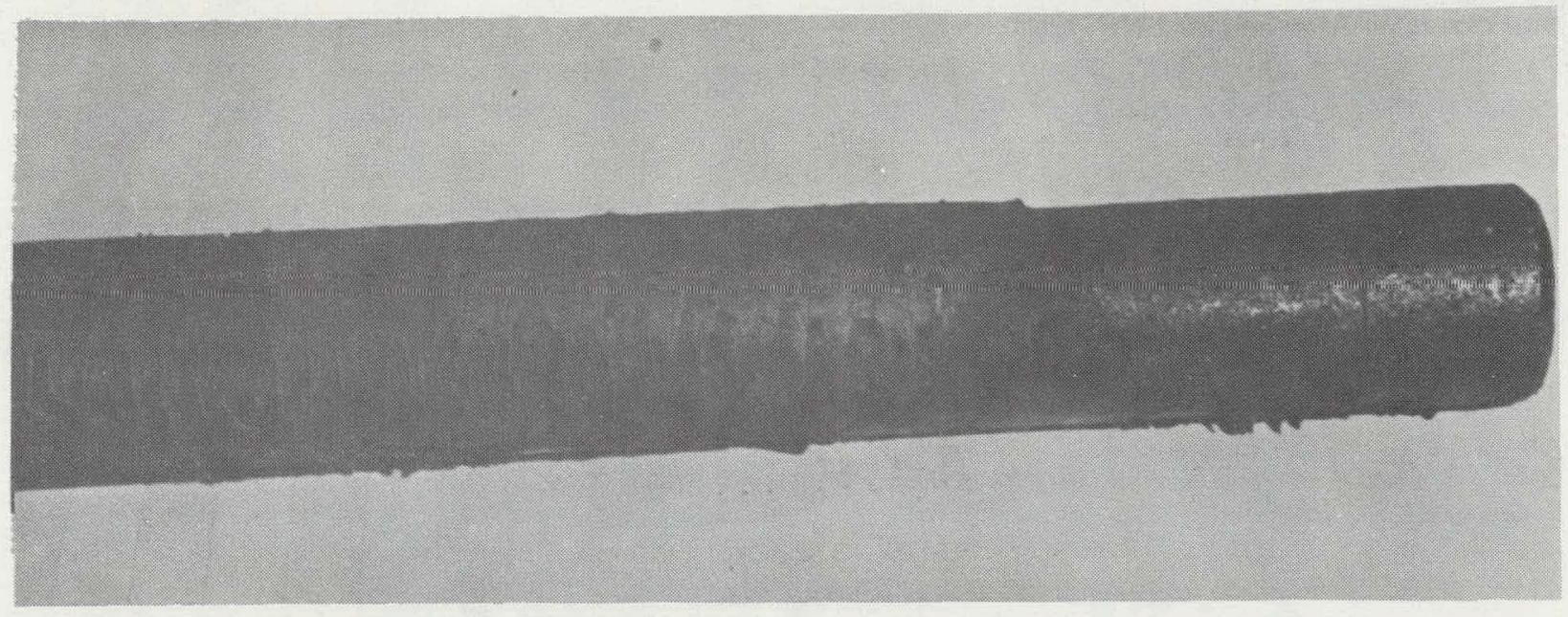

a) Front

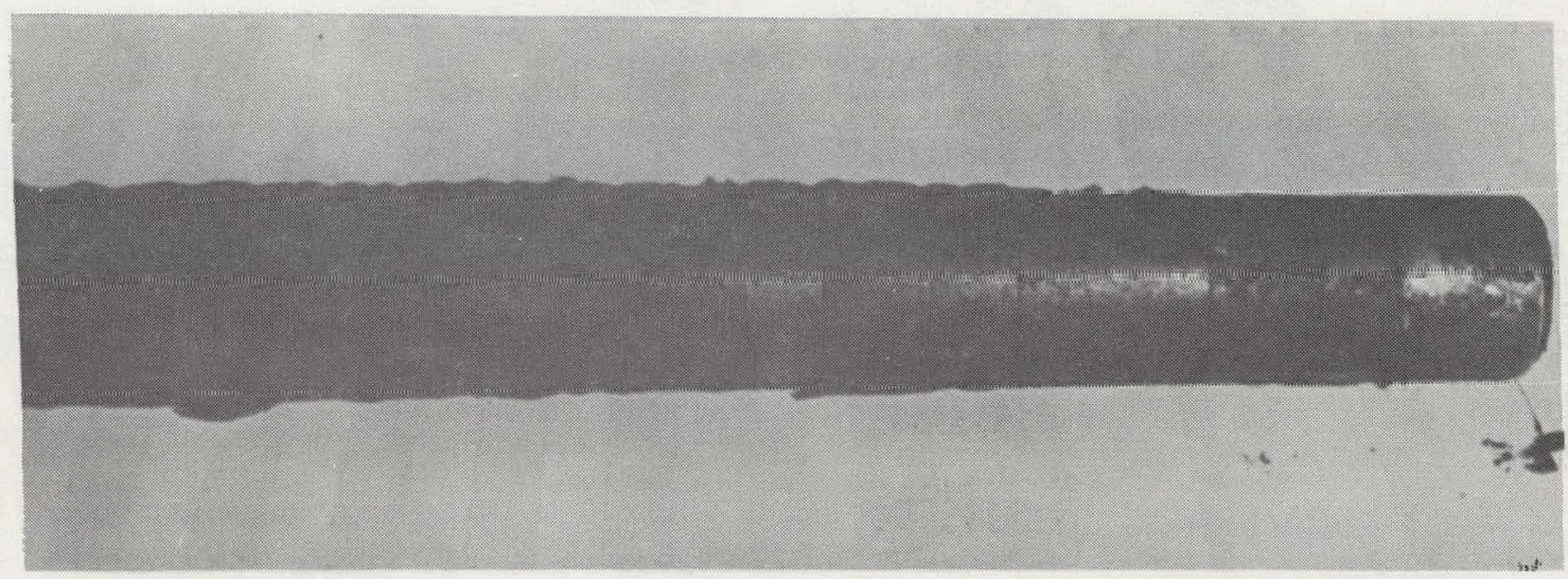

b) Back

Figure 11. Boiler Probe Appearance after Run TP41-04 
probe also became wet to a much lesser extent. These were, as on the previous run, very hard and adherent and were about $2.54 \mathrm{~mm}$ thick. Samples $1,2,3$ and 5 were removed, cleaned and weighed. Figure 12 shows the extensively pitted surface of sample 5. SEM/EDX examination was made

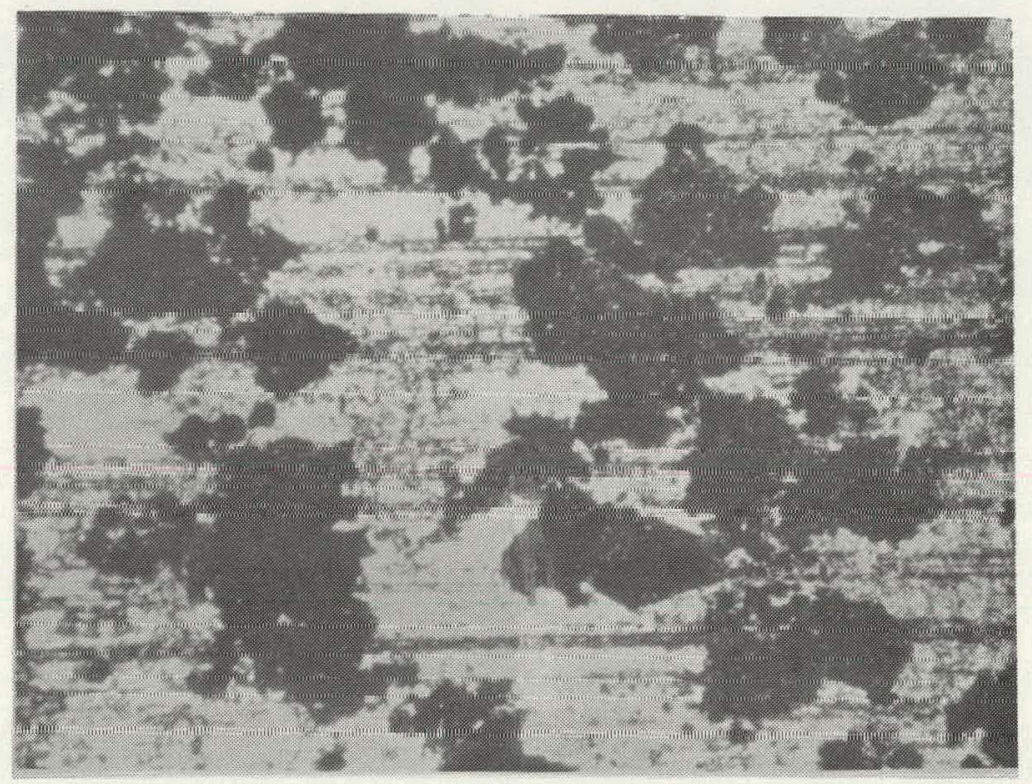

\section{Figure 12. Pitted Surface of Boiler Probe Samples after Run TP41-04, 50X}

across the thickness of the deposit of sample 4 as depicted in Figures 13-16. Figure 13 shows the deposit metal interface along with an EDX scan on the metal which had some deposit material over it. Iron, potassium, sulfur and small amounts of silicon and aluminum were identified. Figure 14 again shows the interface, with an EDX scan at the interface region. The iron intensity was reduced, as was that of the sulfur. The relative intensity of the potassium and silicon peaks was increased and a small amount of chlorine was identified. The interface region seems comprised of relatively loose, low density material. Figure 15 shows the next layer of material, it appearing to have the highest density. No iron or chlorine was found and the sulfur intensity was considerably reduced, as was the silicon slightly. Figure 16 shows the intersection between the intermediate and outer parts of the deposit. The first EDX scan near this intersection showed very little sulfur but large amounts of potassium. The sulfur content increased again at the intersection and reduced again somewhat in the outer deposit. From these observations it appears that the deposit is probably a combination of potassium-sulfur compounds, e.g., $\mathrm{K}_{2} \mathrm{~S}_{4}$, and potassium-carbon-oxygen compounds, e.g., $\mathrm{K}_{2} \mathrm{CO}_{3}$ and $\mathrm{KOH}$. The amount of potassium-sulfur appears to decrease outward from the metal surface through the inner deposit and then increase somewhat in the outer deposit. The major component in the bulk of the deposit is probably $\mathrm{K}_{2} \mathrm{CO}_{3}$ from the evidence of the EDX scans and the fact that the deposit is highly hyg roscopic. 


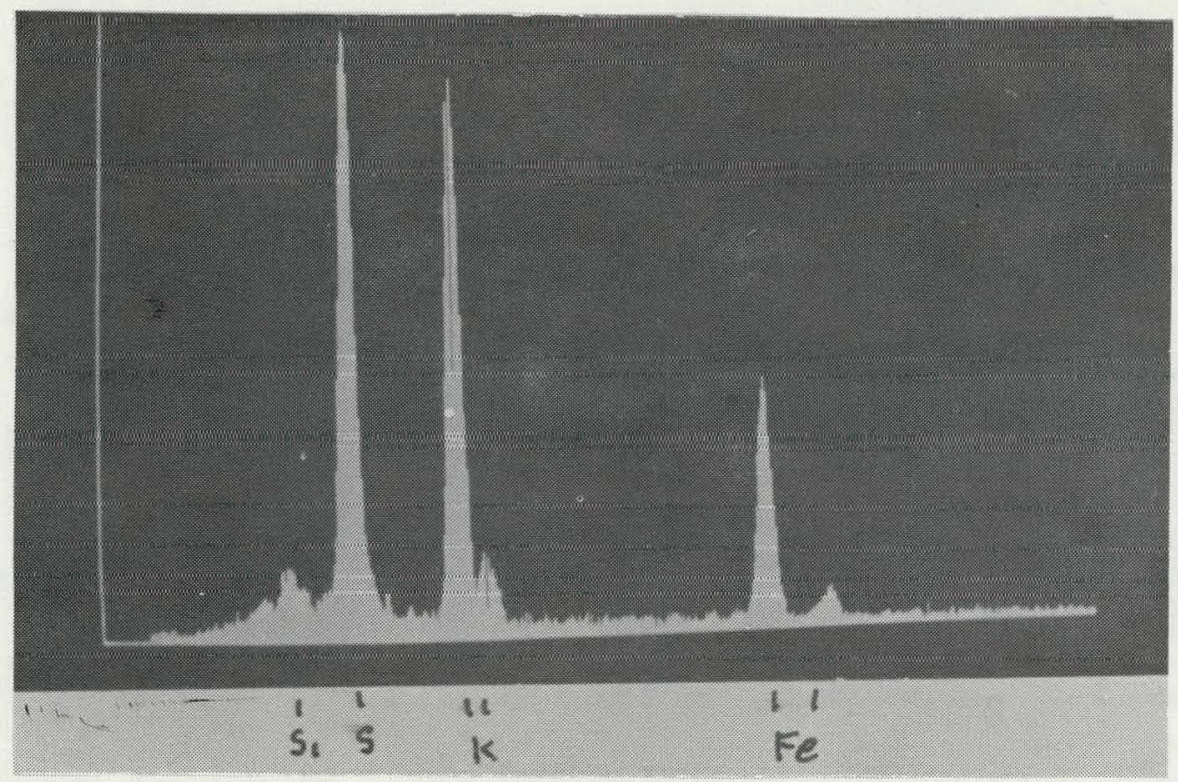

Inner Deposit Metal

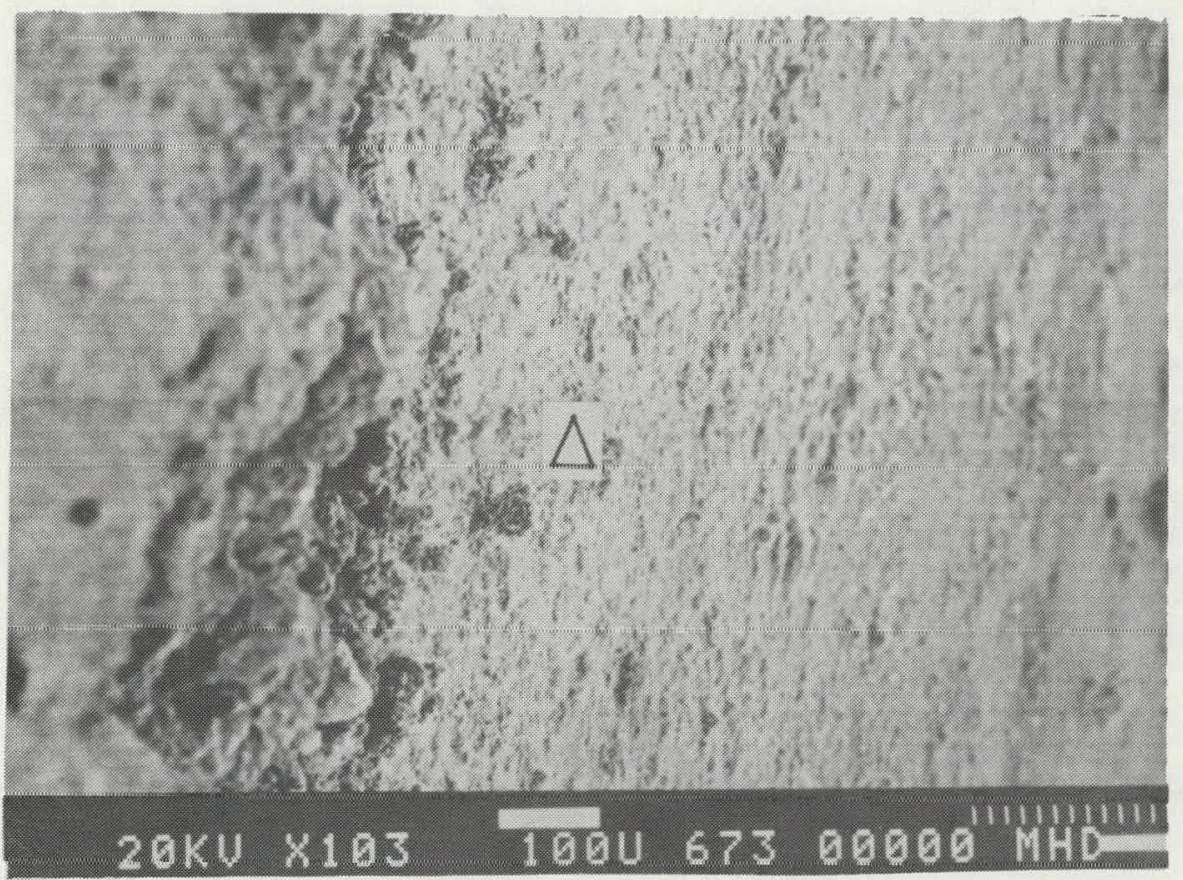

Figure 13. SEM Photograph and EDX Spectrum at a Point Inward of the Deposit on TP41-04 Sample 4 

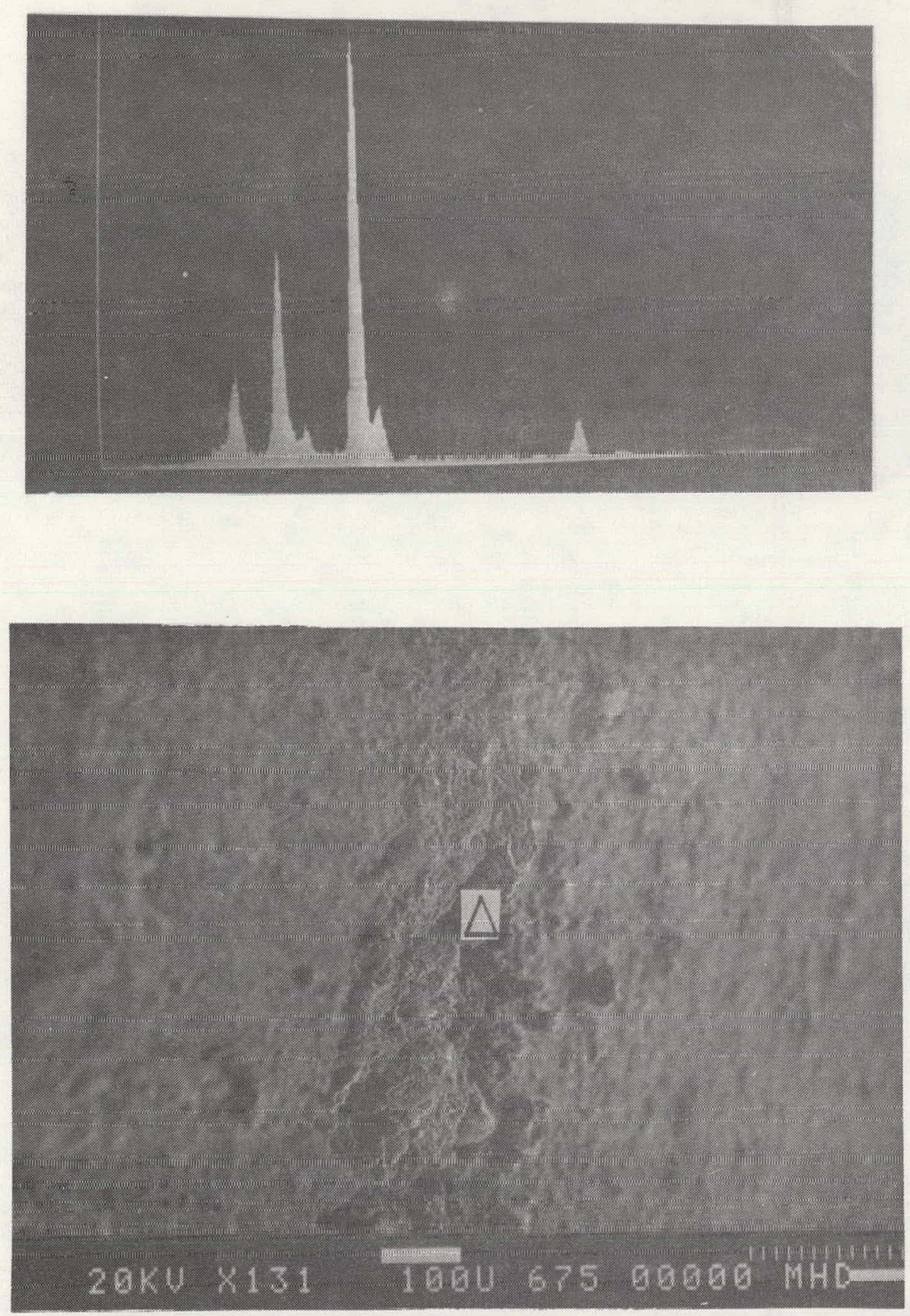

Inner Deposit

F1gure 14. SEM Photograph and EDX Spectrum of the Inner Deposit of TP41-04 Sample 4 


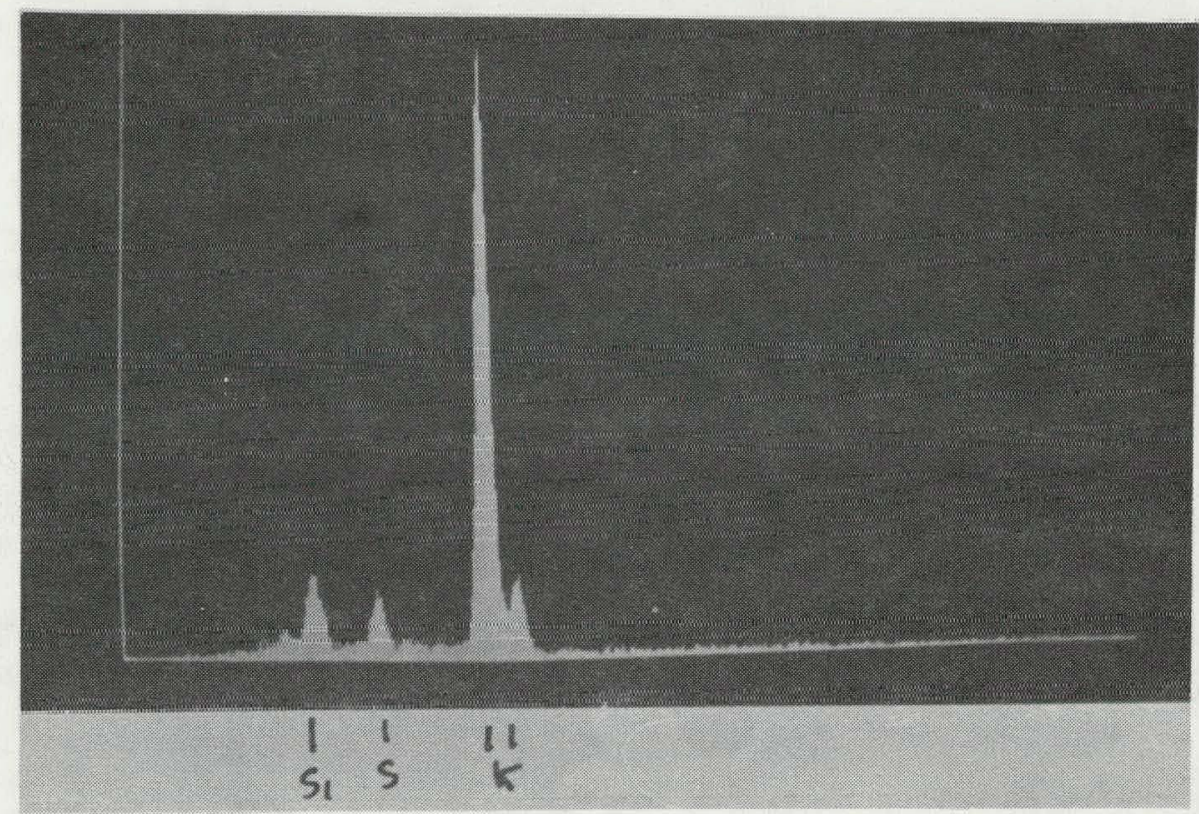

Outer Deposit / Intermediate Deposit / Inner Deposit

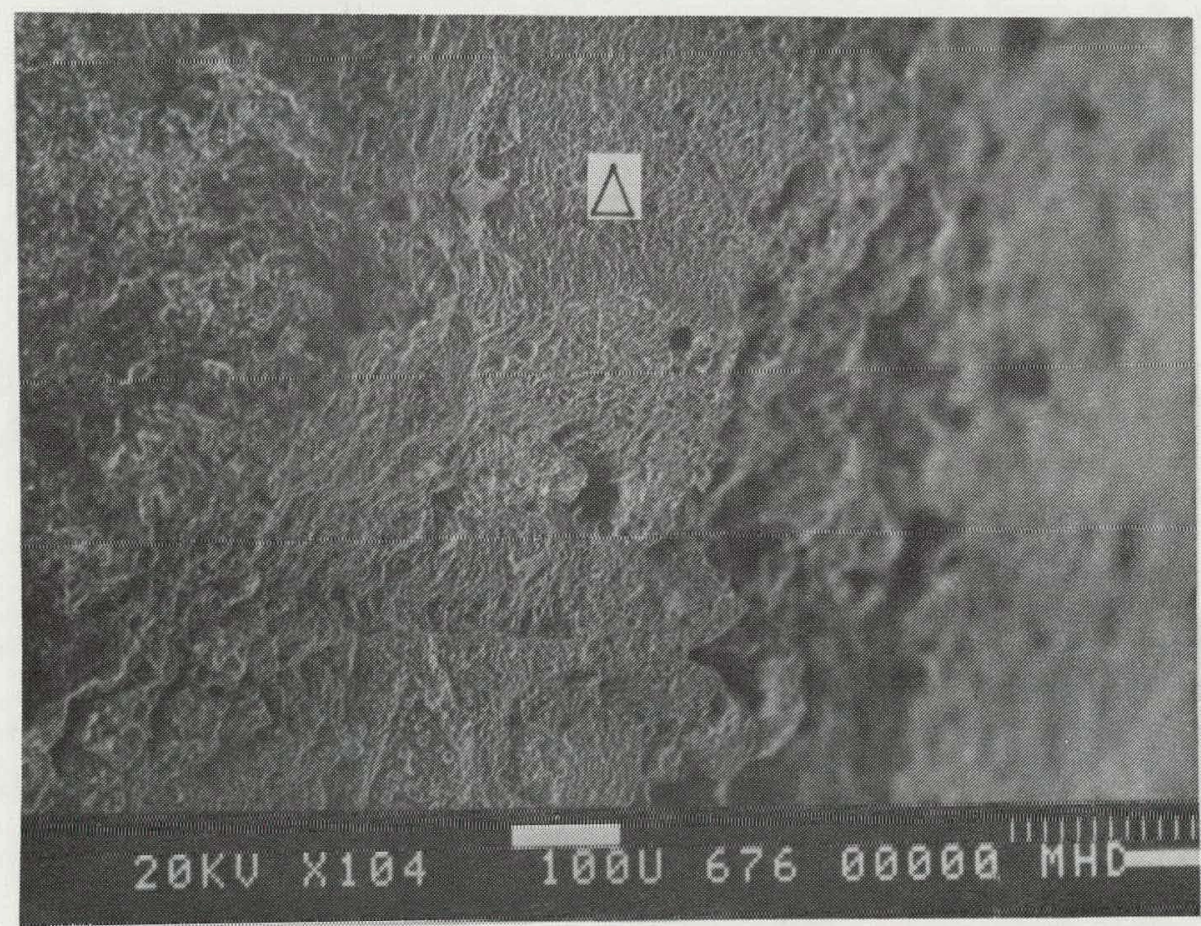

Figure 15. SEM Photograph and EDX Spectrum of the Intermediate Deposit of TP41-04 Sample 4 

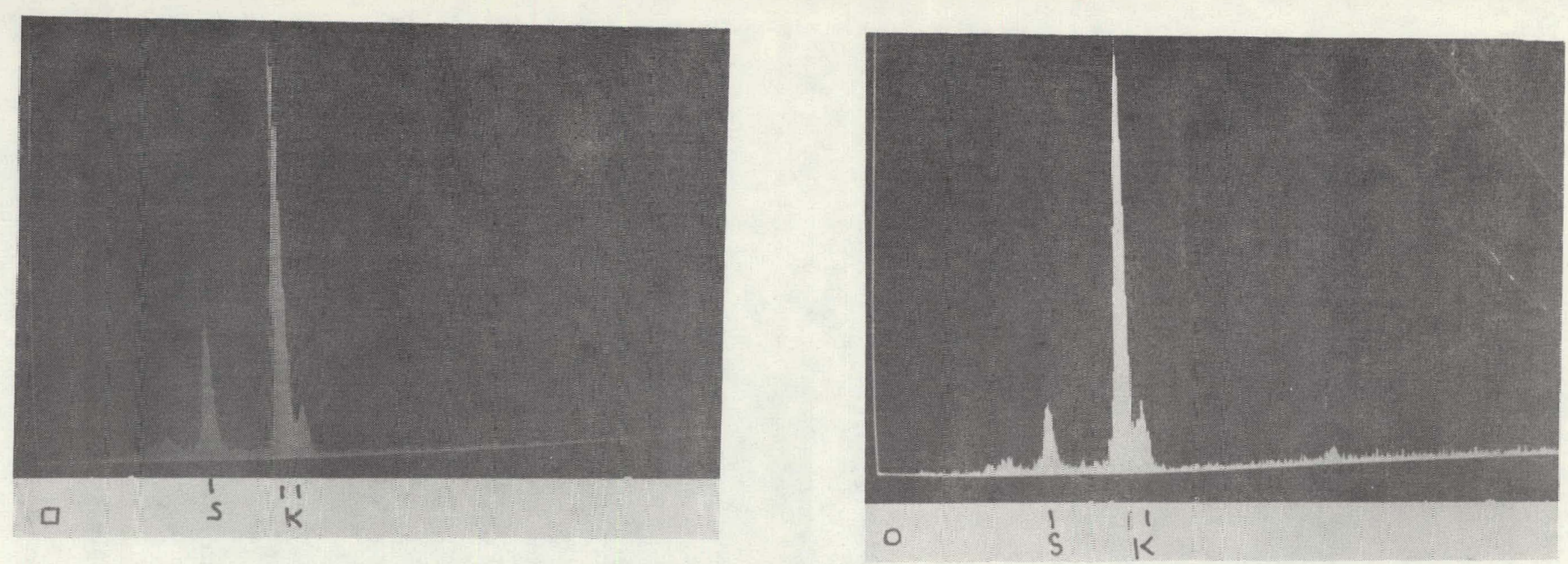

ก
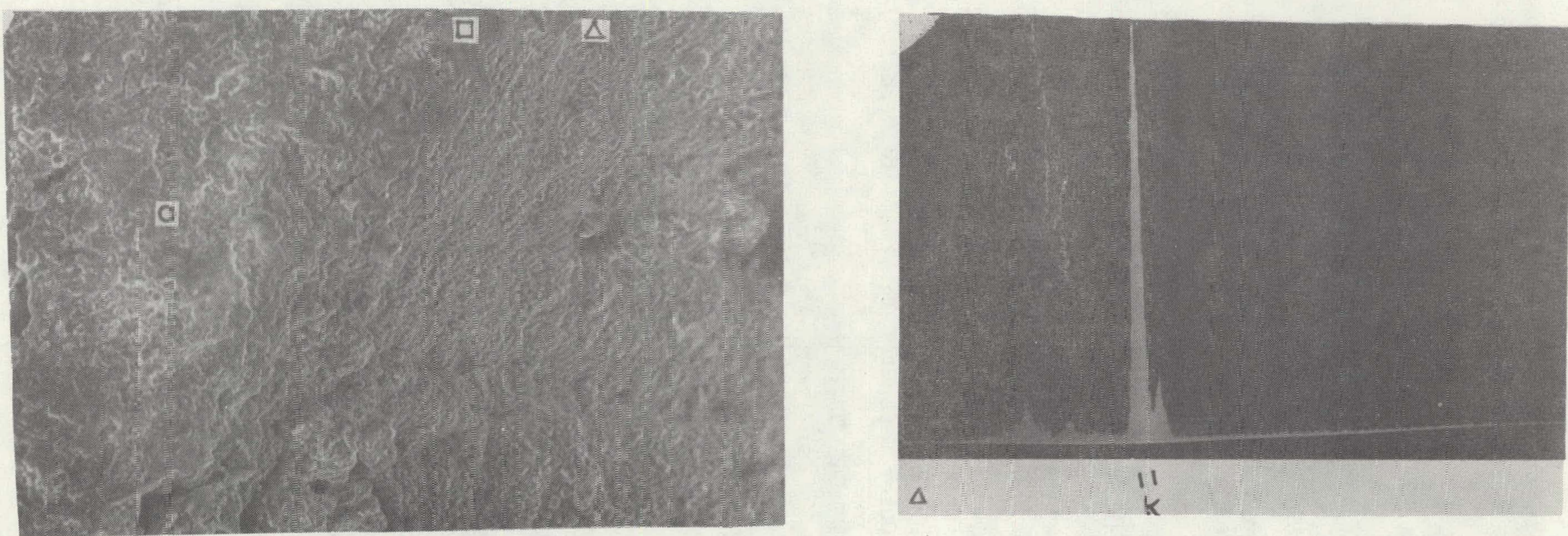

0.uter Deposit / Intermediate Deposit

Flgere 16. SEM Photograph $(236 \mathrm{X})$ and EDX Spectra at Locatiors Asross the Deposit Thickness of $(ᄃ, 0, \Delta=$ I.scation of EDAX Scan) TP41-04 Sample 4 
TP41-05 ran about 57 minutes total. The probe was left in over the weekend so that it had absorbed a considerable amount of water. Most of the deposit fell off before or during removal. The probe is shown in Figure 17. The deposit that was not removed was about $1.78 \mathrm{~mm}$ thick. Optical micrographs of the cross-section of the deposit are shown in Figure 18. As in the previous test, three distinct layers of deposit are evident. The one next to the tube is dark gray or black and has apparently relatively loose, porous material. The second or middle layer is crystalline, and clear to white to reddish in color. The outer layer is dark gray and amorphous, but with somewhat finer, less porous texture than the inner layer. Figures 19 and 20 show the surface appearances of the middle and end samples. The severity of corrosion is seen to increase with increasing temperature, with the principal mode of attack being pitting. However, at sample 7 there is a change in mode to primarily sheet type corrosion. Each sample was again weighed.

TP41-06 was terminated after a few minutes on coal due to a computer failure. TP41-07 ran a total of about 63 minutes. This time the probe was removed as soon as it had cooled sufficiently. Figure 21 shows the appearance of the probe. Considerable yellow-green color was evident along with the usual gray. Micrographs of the sample surfaces are shown in Figures 22 and 23. Here the transition to sheet type corrosion was seen to occur at the front of the probe about midway of sample 6 . The corresponding actual temperature is unknown since the thermocouples are located at the rear of the probe. The temperature at the rear at that position would be about $688 \mathrm{~K}$ $\left(415^{\circ} \mathrm{C}\right)$. Appreciable attack had not begun on the back side until sample 4, i.e., at about $633 \mathrm{~K}\left(360^{\circ} \mathrm{C}\right)$. Again each specimen was weighed.

SEM and EDX examination was also made of the surface of sample 4. Figure 24 shows a smooth area largely free of corrosion pits. However, the fuzziness of the surface indicates the presence of some type of scale, i.e. oxide and/or sulfide. The EDX scan of this area is shown also, iron and sulfur being the only principal constituents. Figure 25 shows a heavily corroded area. The cracked grain-like structure again indicates a surface scale. Thé EDX scan shows a somewhat higher sulfur level than in the uncorroded area and slightly more potassium. The scale is probably a mixture of iron sulfides and oxides, mostly FeS based on the substoichiometric atmosphere and the black color.

Some of the next Test Plan 41 conditions were considered inappropriate for use of the corrosion probe. Most of these included the addition of limestone instead of potassium carbonate to the coal for sulfur removal. However, the next two runs, TP41-13 and 14, in which the probe was used, also had limestone added, as noted in Table V.

TP41-13 ran for about 32 minutes under steady-state conditions. The boiler probe was removed as soon as sufficiently cooled, its appearance being shown in Figure 26. The front side deposit was dark gray with a greenish color toward the cool end. The topography was rather rough at the front, especially toward the middle. This deposit was thickest at sample 3 , being about $3.18 \mathrm{~mm}$, becoming continually thinner toward the hot end where it was about $0.76 \mathrm{~mm}$ thick. As always, where the main deposit had fallen off, the underlying material had a black, sooty appearance. The deposits were not removed after this test. Instead, the probe was stored in dessicant until the next run. 


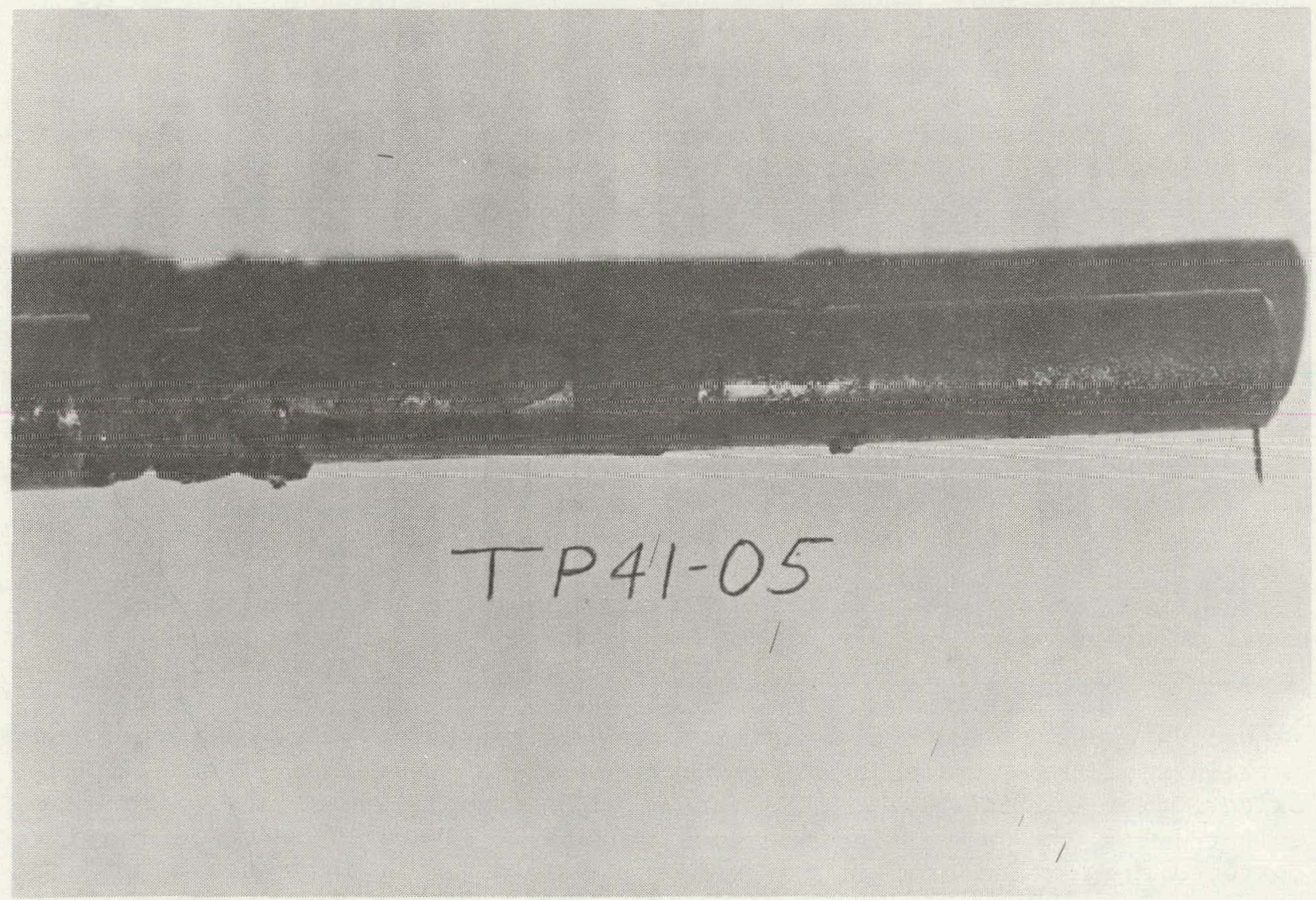

Figure 17. Boiler Probe Appearance after Run TP41-05 


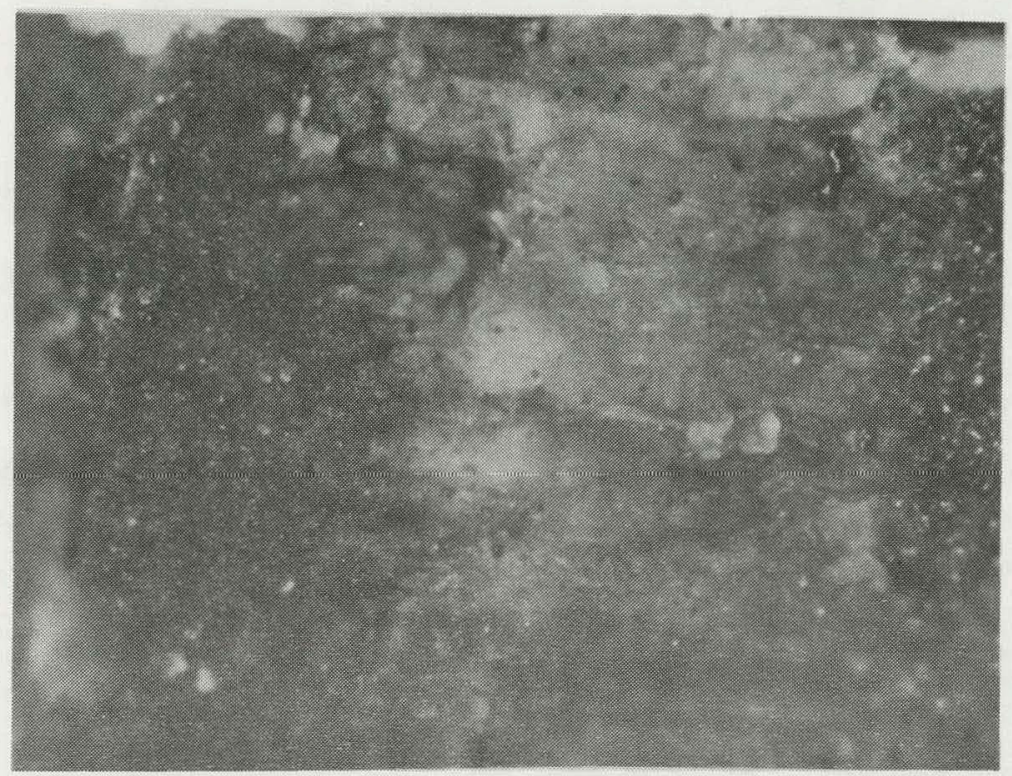

Outer Deposit / Intermediate Deposit

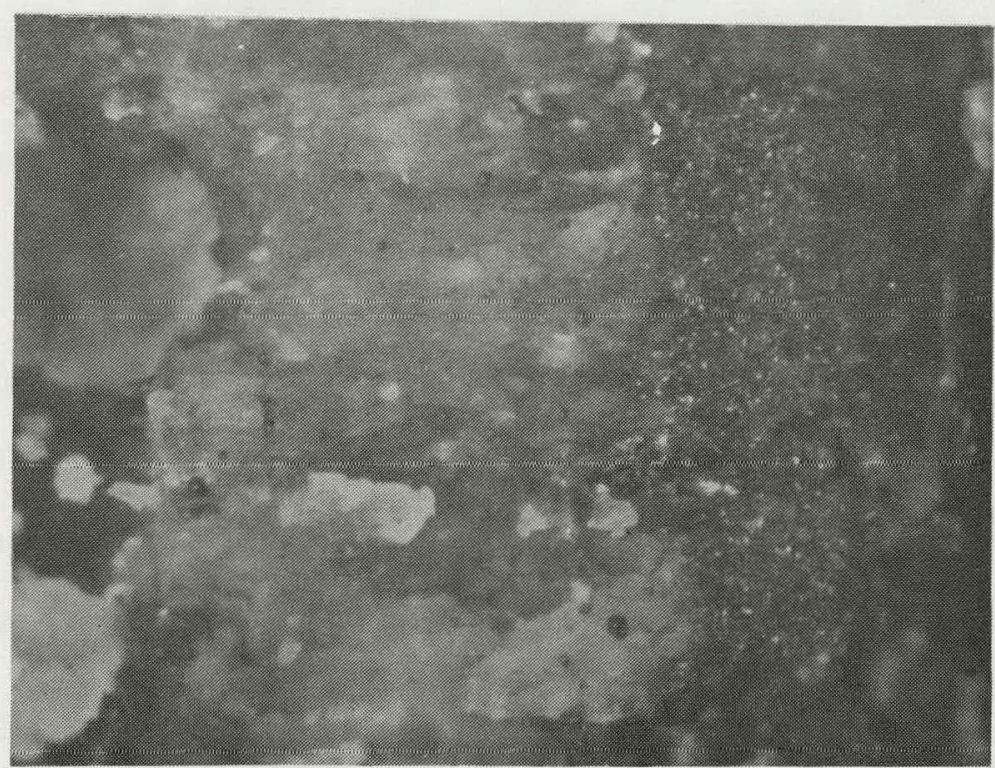

InLermediate Deposit / Inner Deposit

Figure 18. Cross-Section of Boiler Probe Deposit on TP41-05 Sample 4, 62.5X 


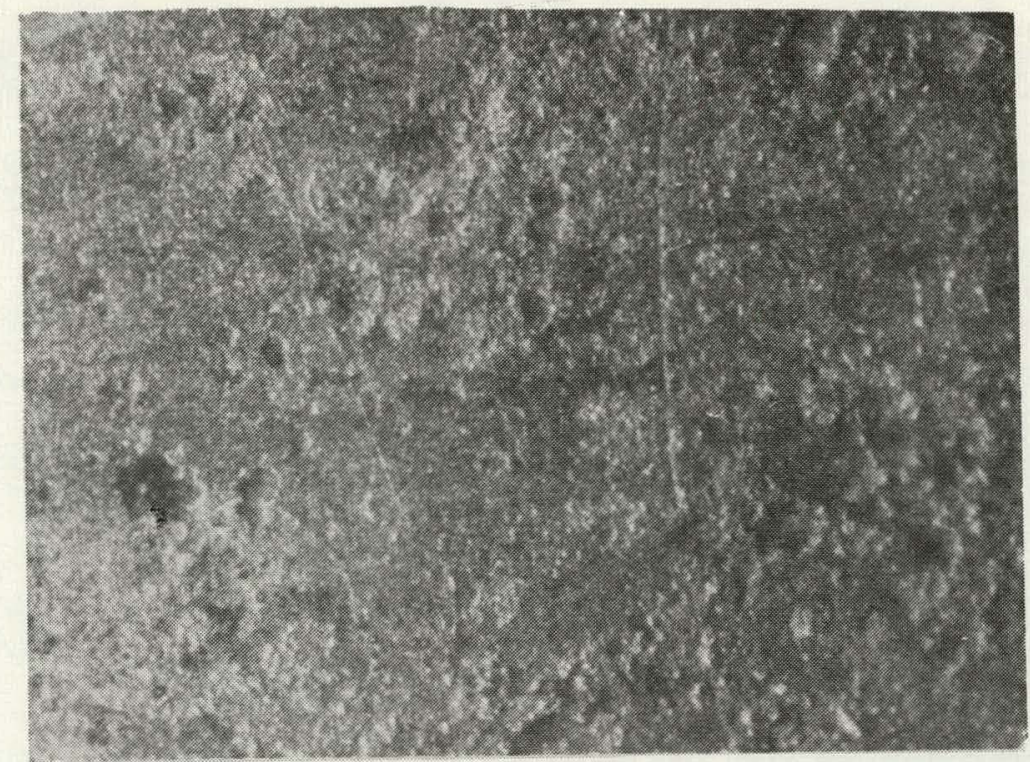

a) Sample 1

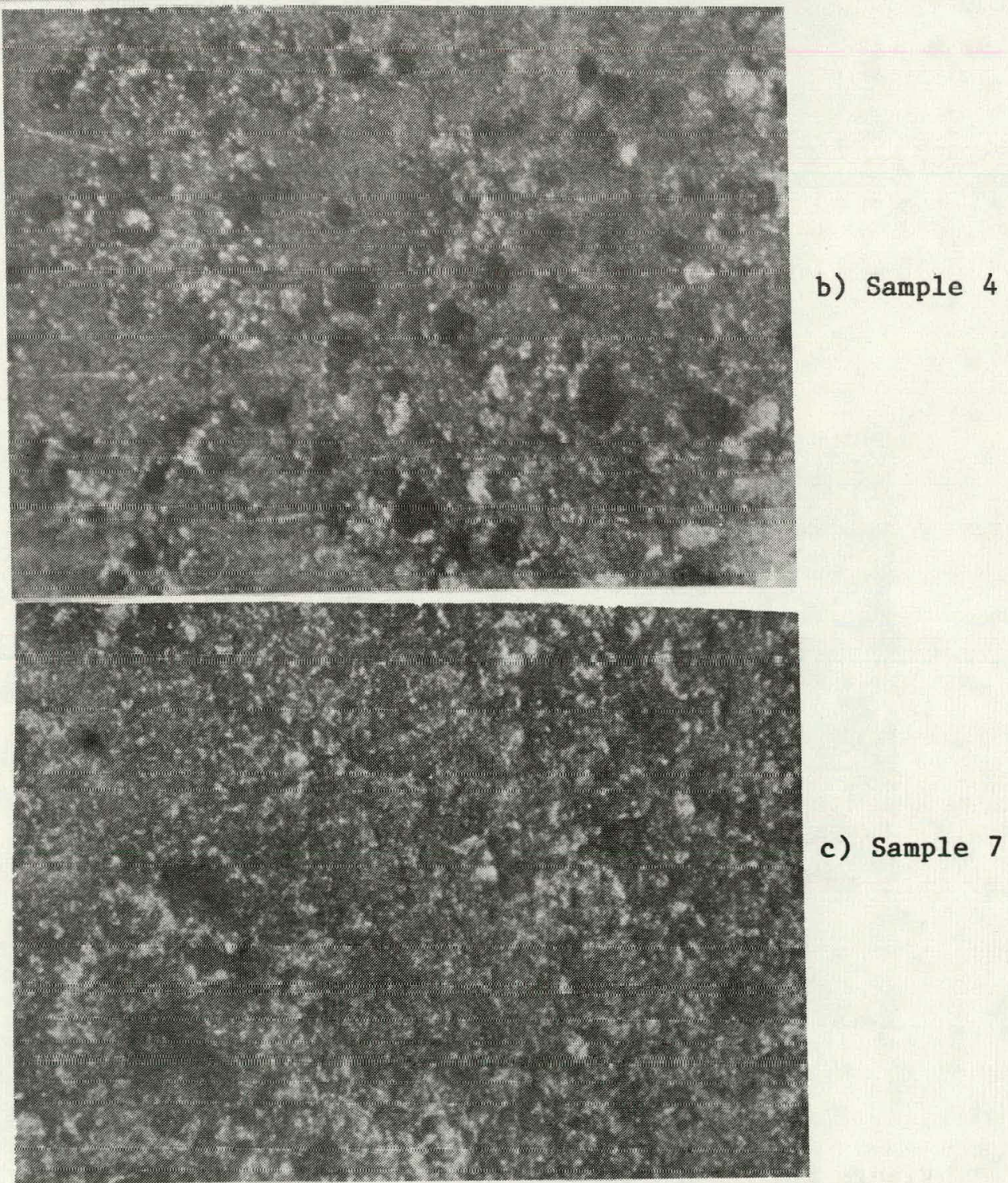

Figure 19. Boiler Probe Front Surface Appearance after Run TP41-05, 62.5X 


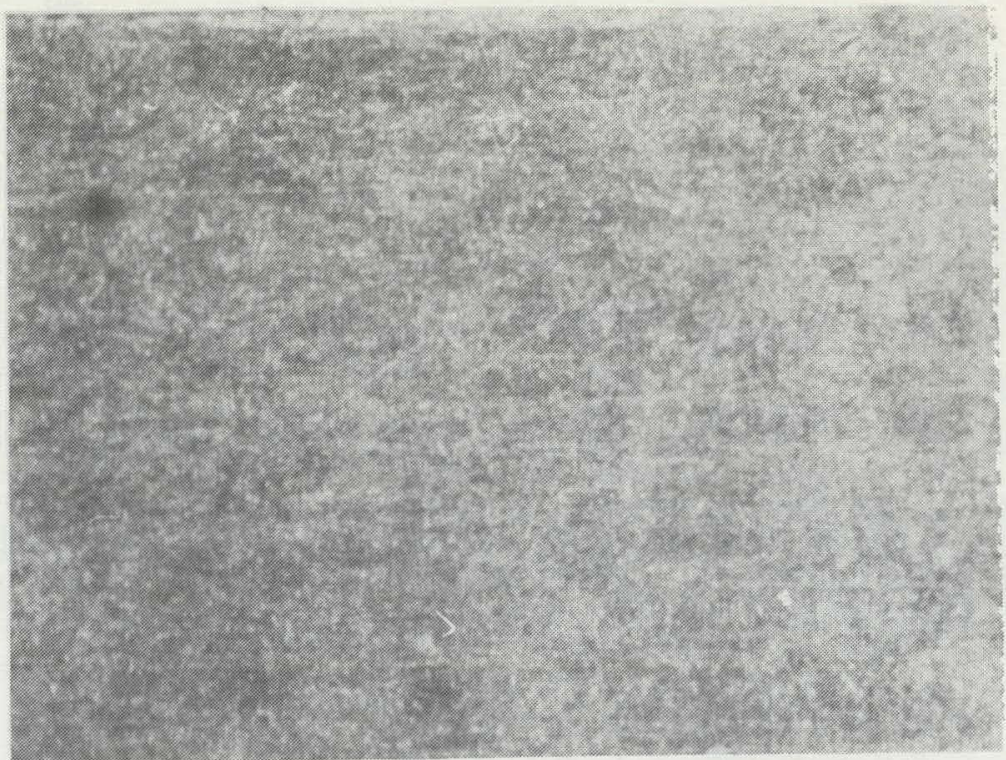

a) Sample 1

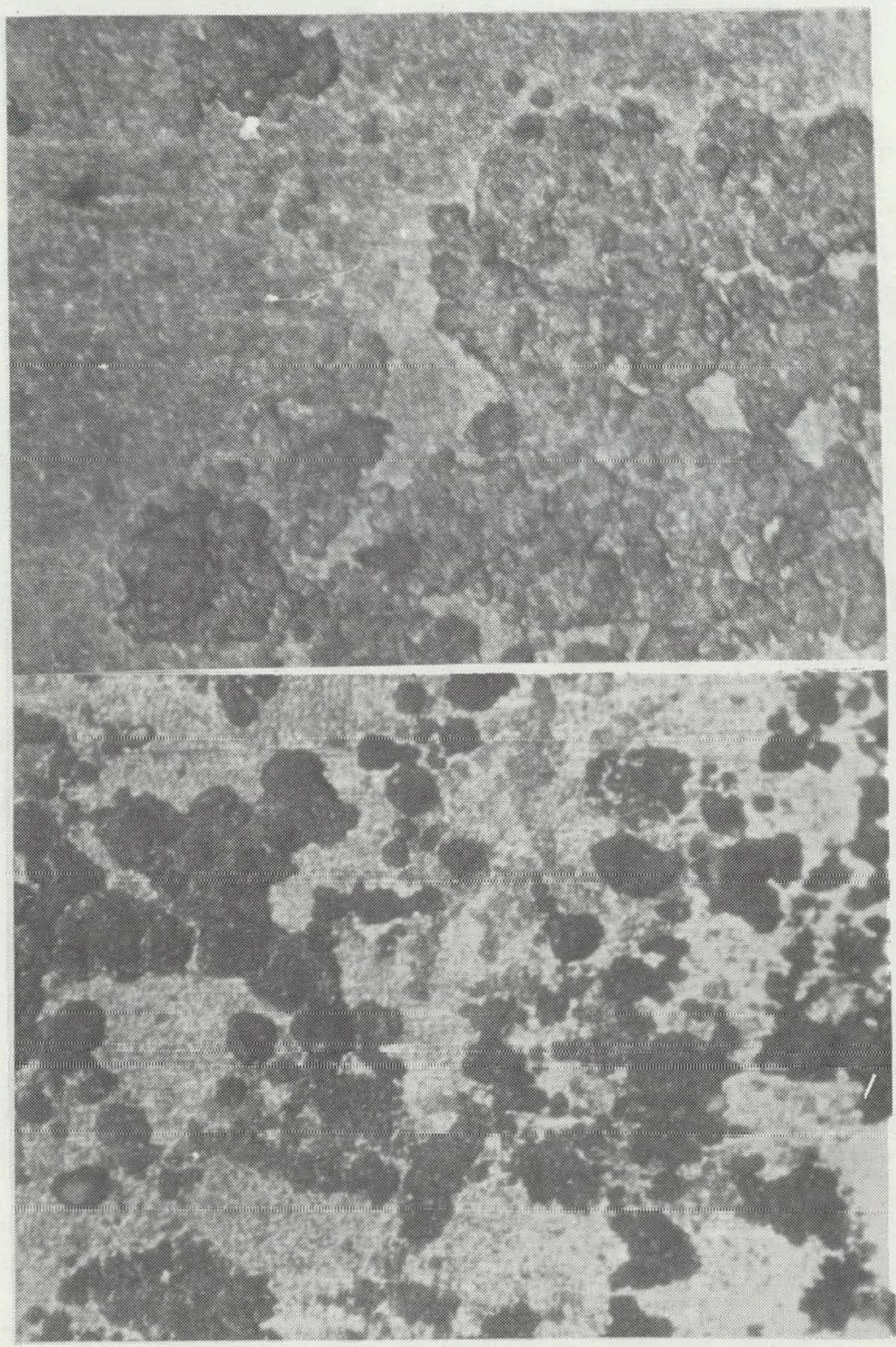

b) Sample 4

c) Sample 7

Figure 20. Boller Probe Back Surface Appearance after Run TP41-05, 62.5X 


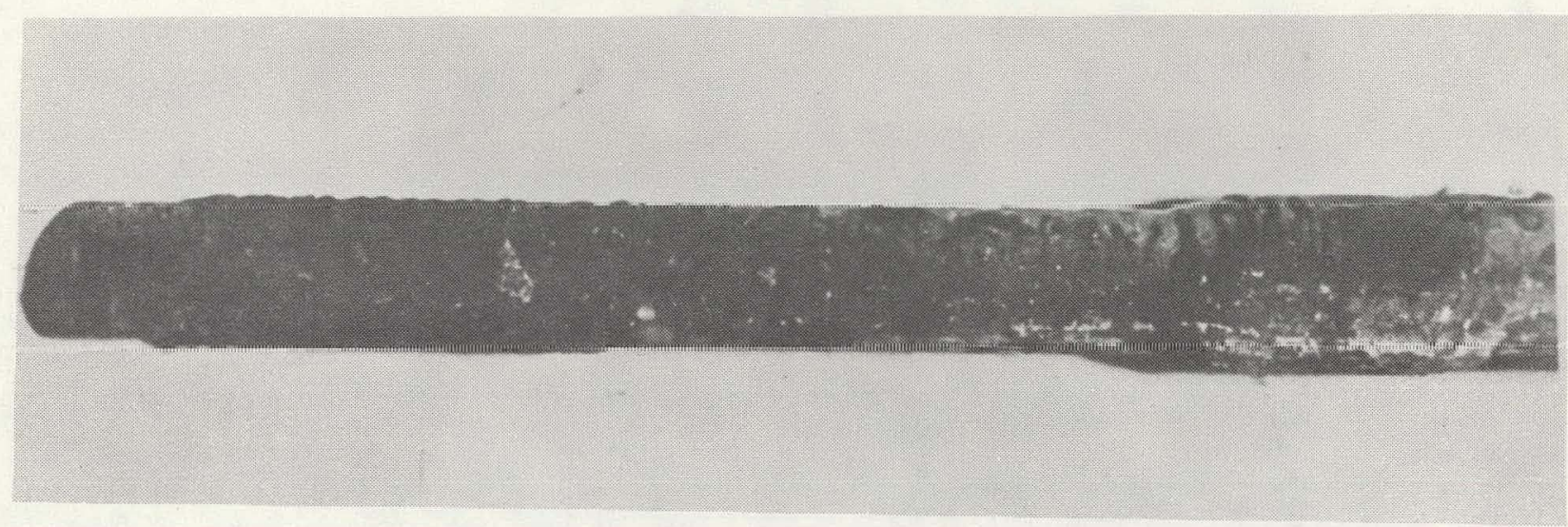

a) Front

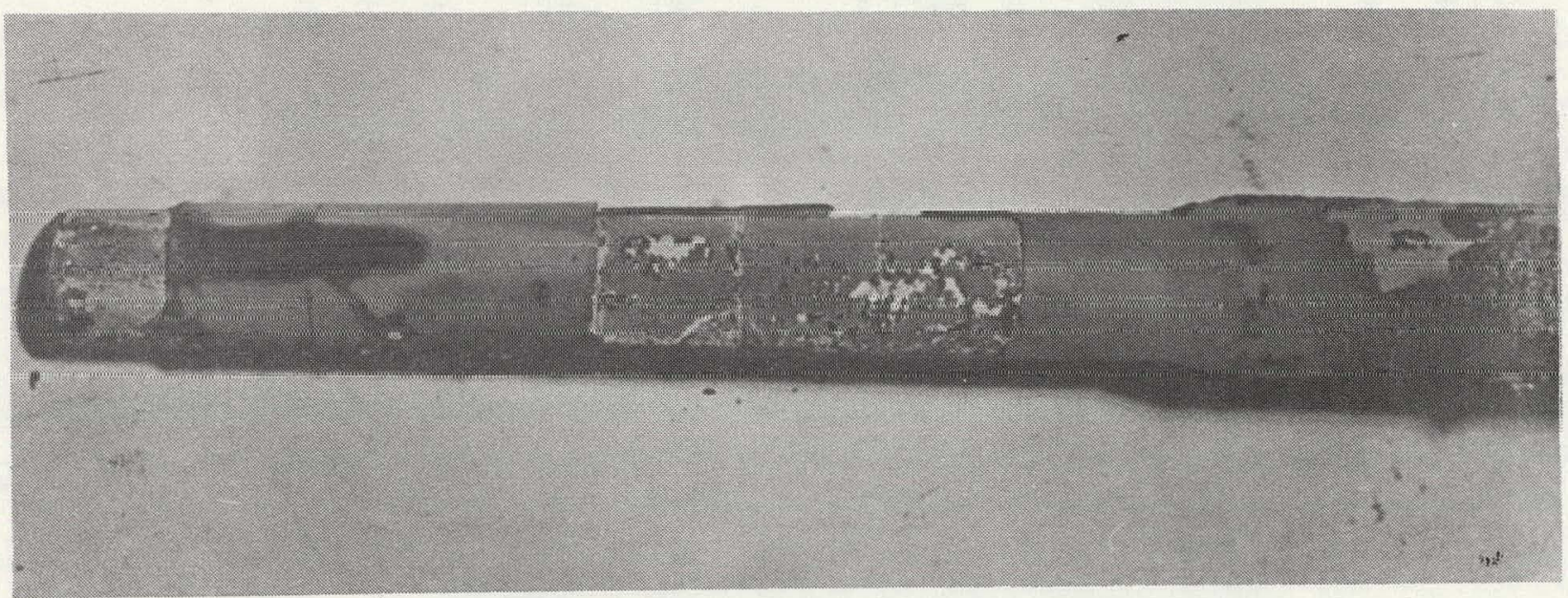

b) Back

Figure 21. Boller Probe Appearance after Run TP41-07 


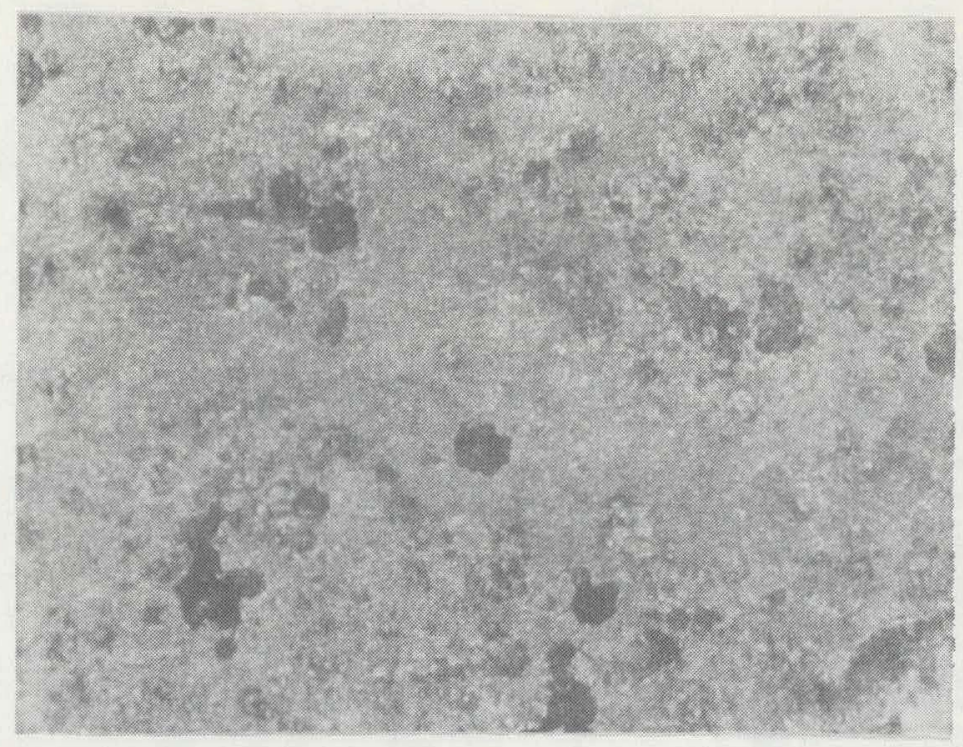

a) Sample 1

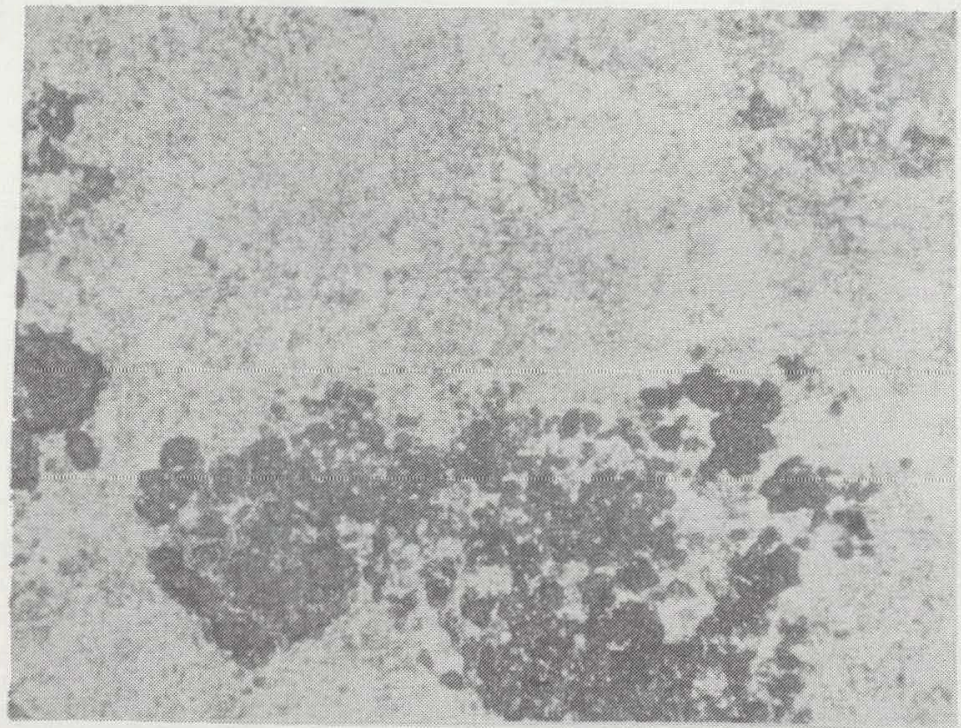

b) Sample 4

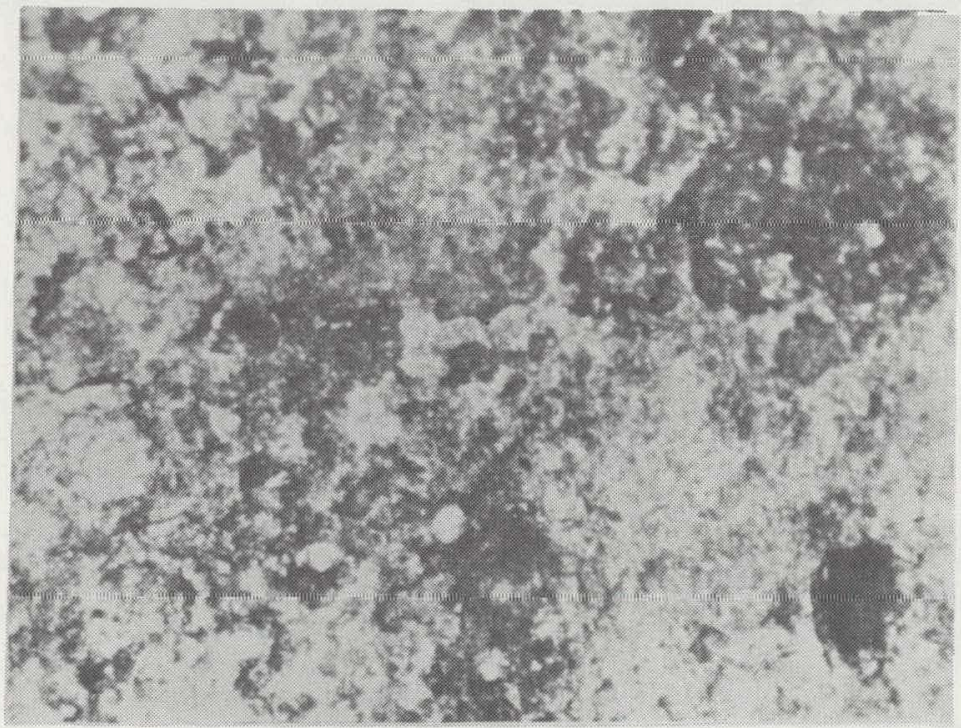

c) Sample 7

Figure 22. Corroded Front Surface of Boiler Probe Samples after Run TP41-07, 62.5X 


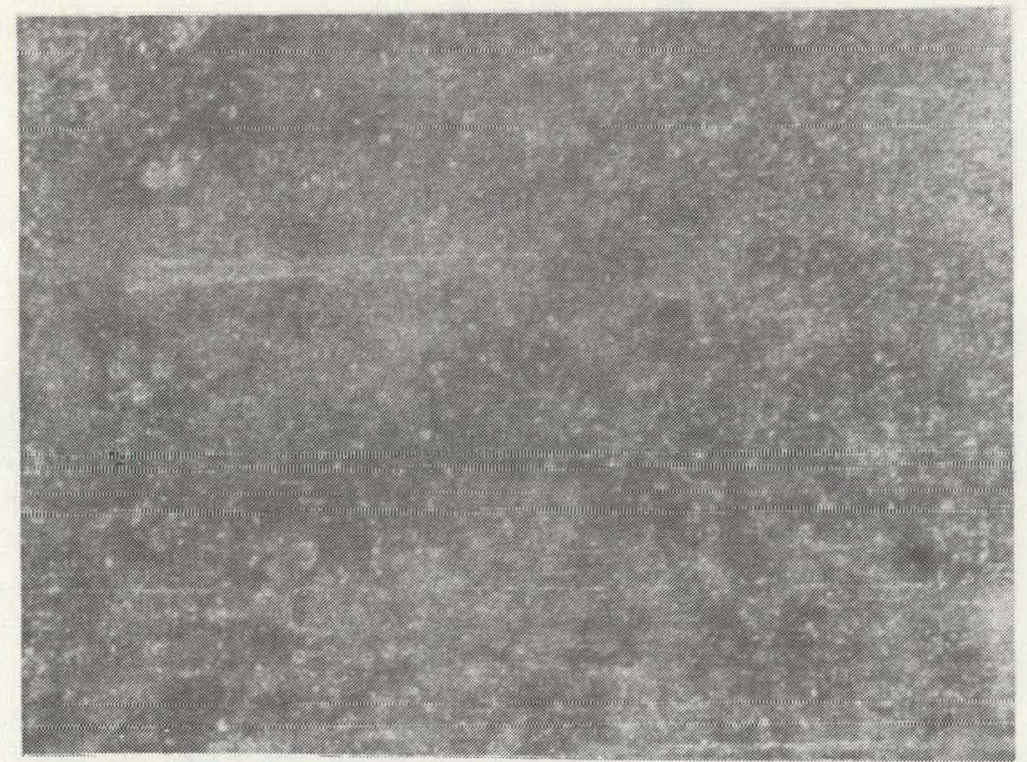

a) Sample 1

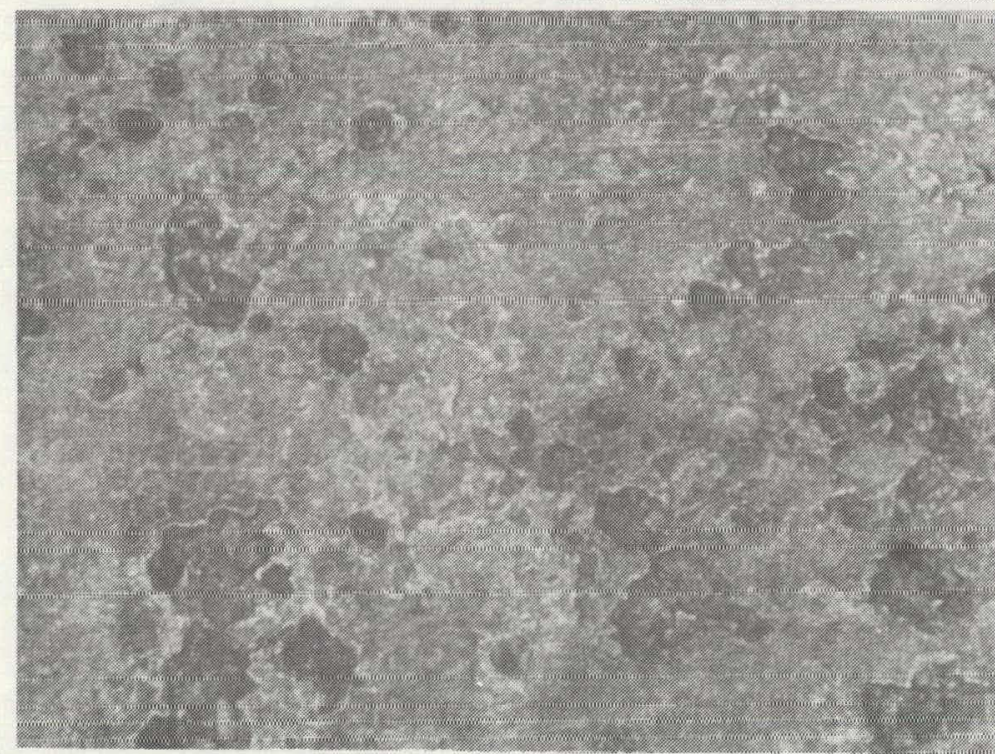

b) Sample 4

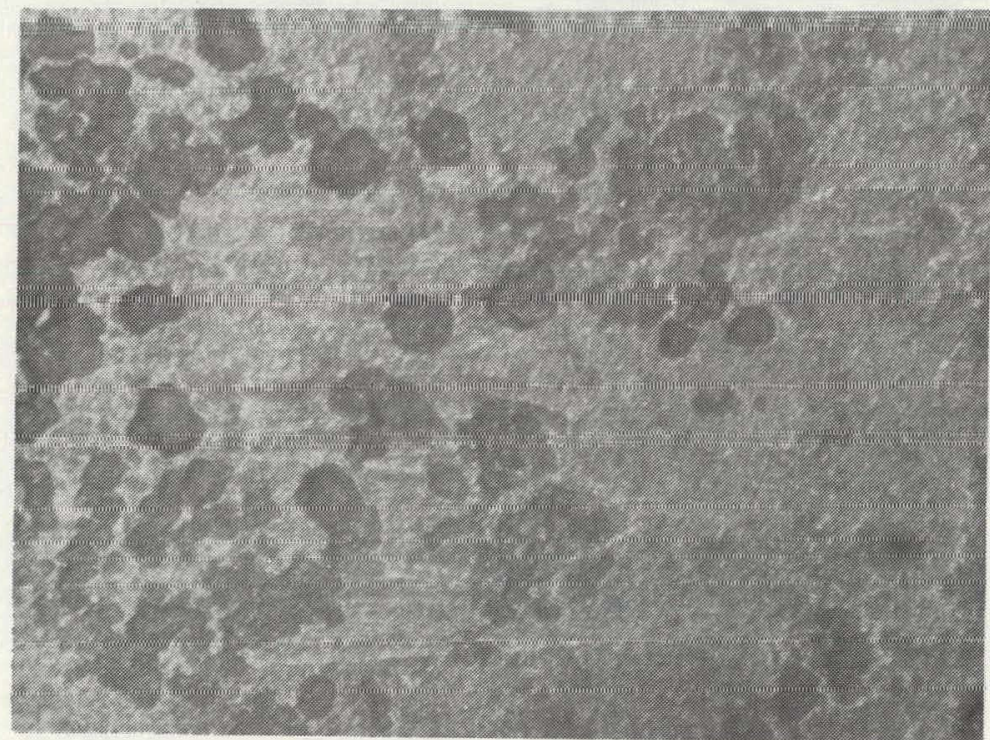

c) Sample 7

Figure 23. Corroded Back Surface of Boiler Probe Samples after Run TP41-07, 62.5X 

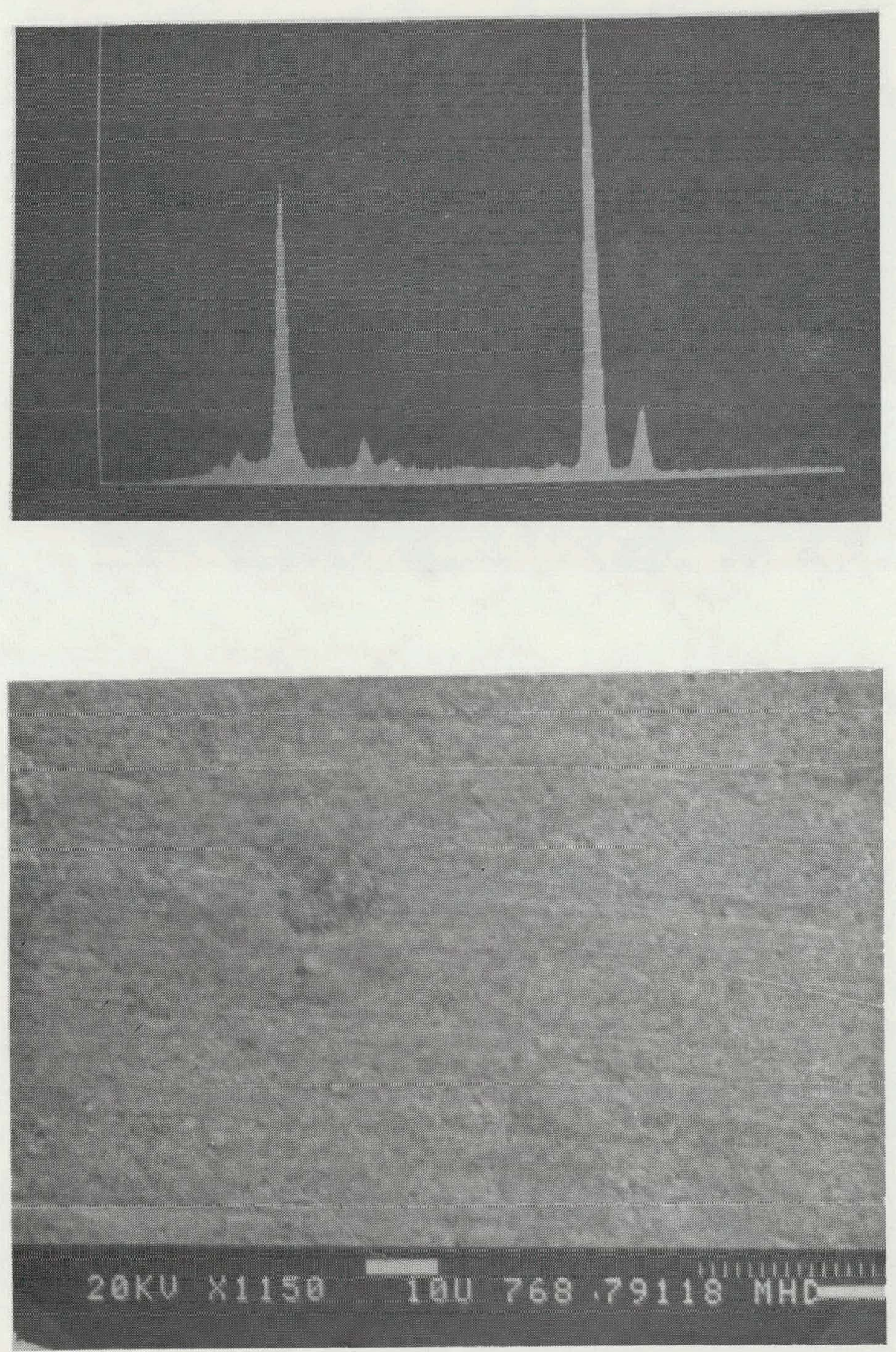

Figure 24. Area of TP41-07 Sample 4, Largely Free of Corrosion Pits 


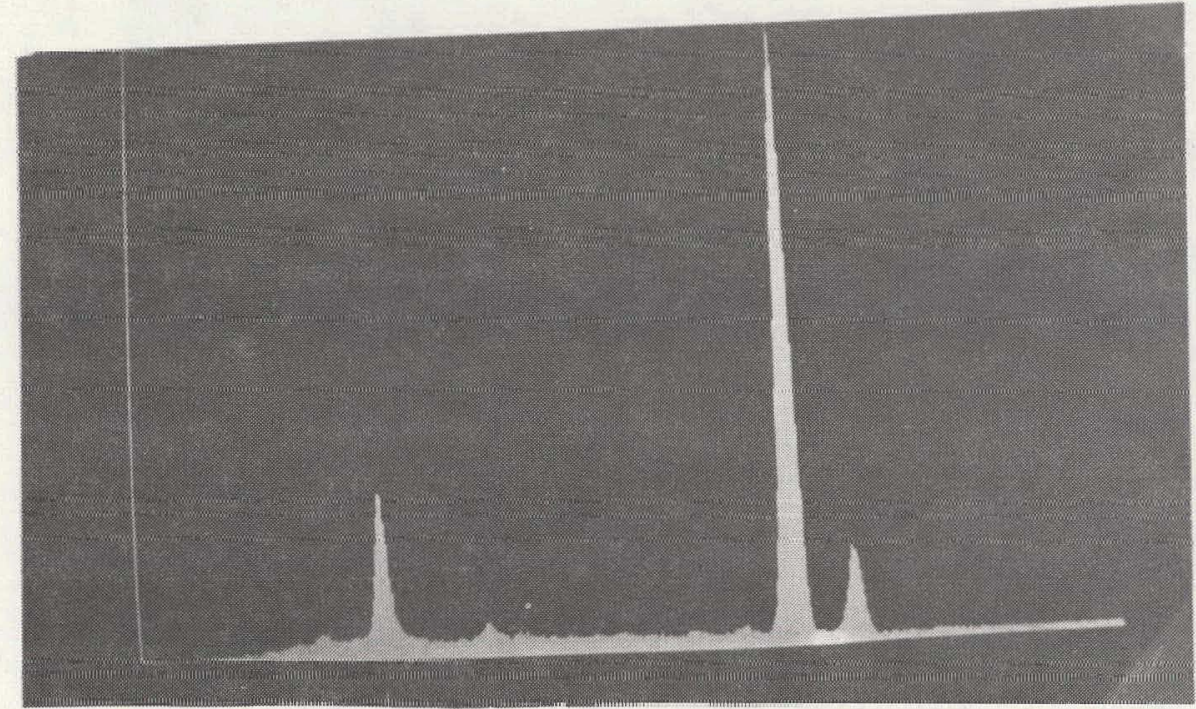

Al Si S K

$\mathrm{Fe}$

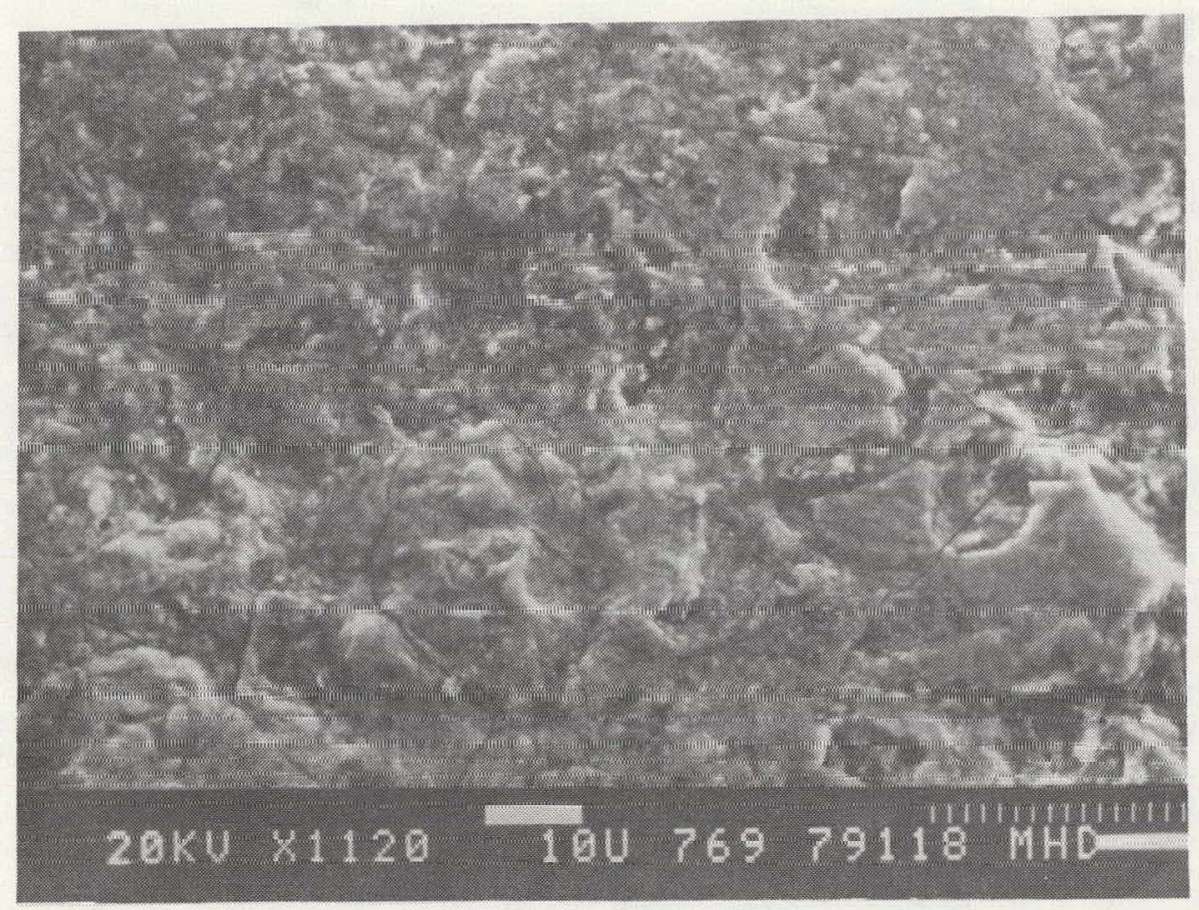

Figure 25. Heavily Corroded Area of TP41-07 Sample 4 


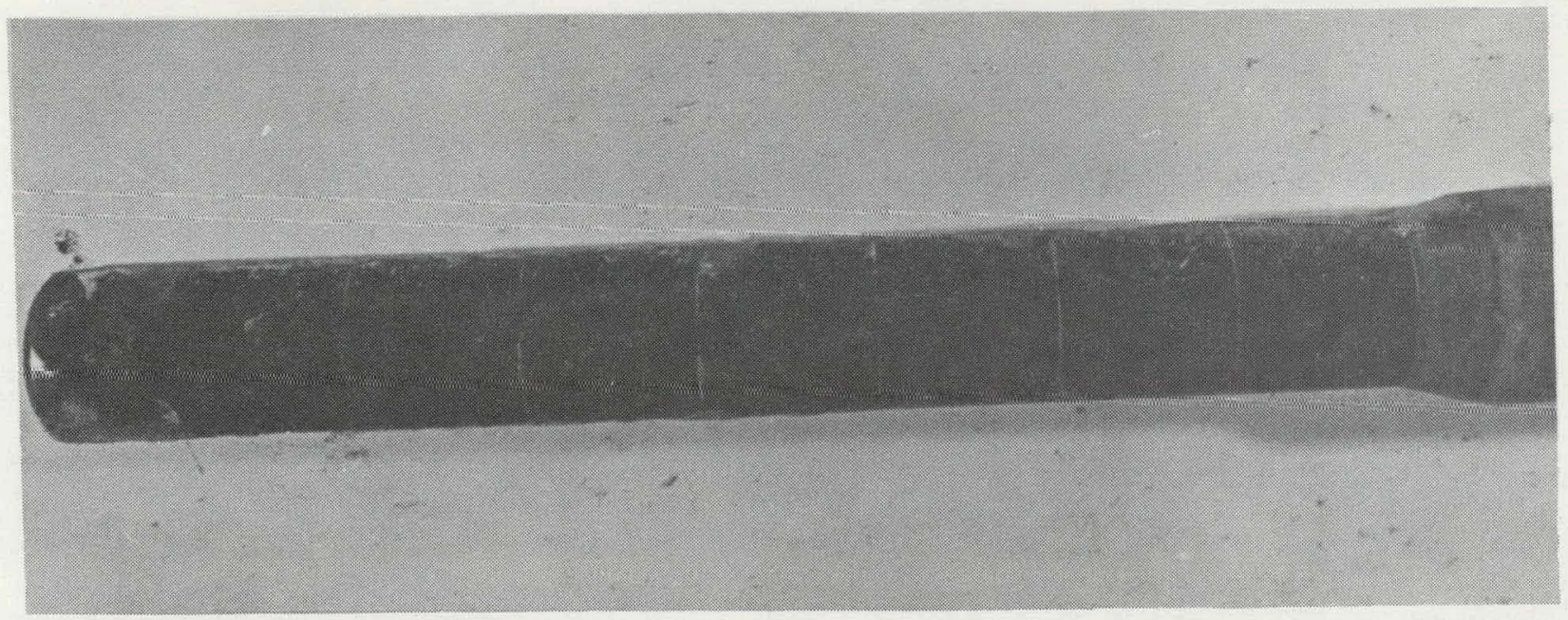

a) Back

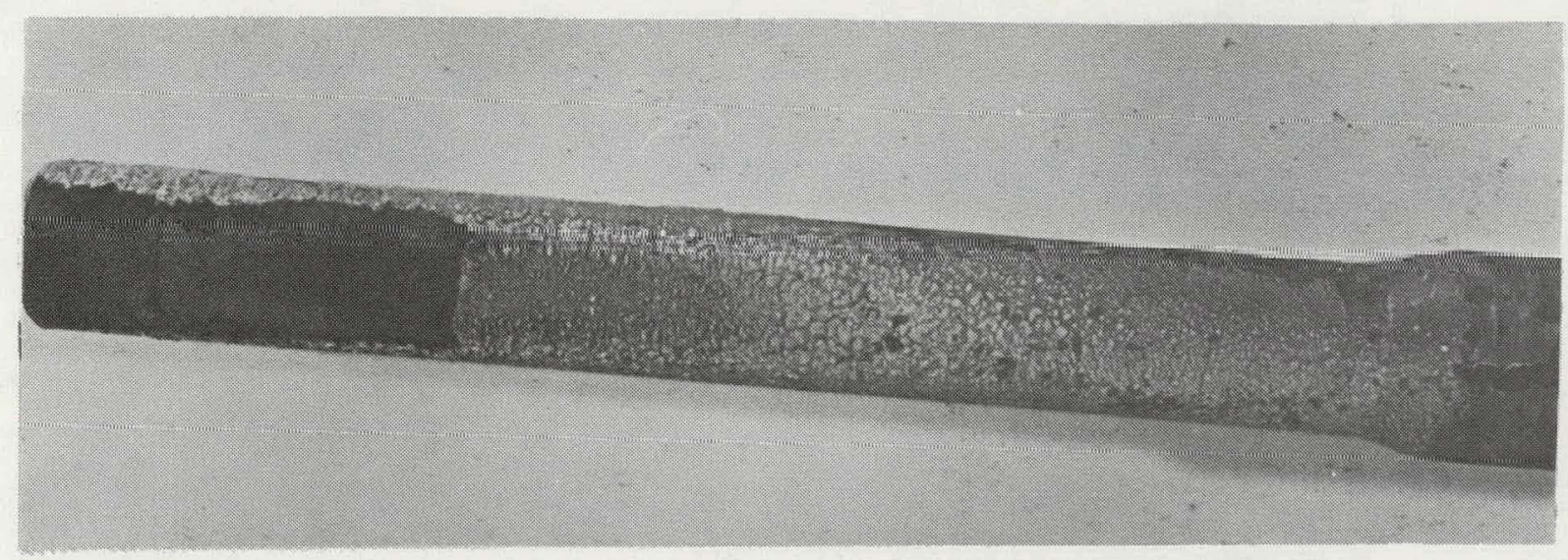

b) Front

Figure 26. Boiler Probe Appearance after Run TP41-13 
TP41-14 ran for about 54 minutes at steady-state. Afterward the boiler probe was, left in the duct over the weekend. Upon removal its appearance was as shown in Figure 27. The deposit was built up to as much as $3.18 \mathrm{~mm}$ on the front of samples 2 and 3. It was very rough, showing streak or stream patterns where liquid material flowed under the action of the gas. The front of the probe is dark gray with considerable greenish color which turned white as it was exposed to air for a while. Underneath the thick deposit was a very thin layer which had the greenish color and also turned white upon exposure to air. The main deposit on the back side of the probe had all fallen off before or during removal from the duct. There was a thin white layer underneath. At the sides there was a green layer over the white and over this was the thicker deposit, which was lighter gray than on the front and very delicate. Wherc the main depusit at the back had fallen off was a very thin black, sooty layer. A considerable $\mathrm{H}_{2} \mathrm{~S}$ odor was uuLed. Deposits were removed from the samples by chipping and stored in individual, marked plastic bags. The remaining material was washed off the samples with water and also saved. Again each sample was weighed.

Examination of the sample surface was again made with the optical microscope. it was found that very little macrocorrosion was present on the front side of samples 1-3. Tt was more extensive, liuwever, on the back sides of samples 2 and 3. Little difference in appearance existed between the downstream sides of samples $3-5$ or the front sides of samples 4-7. On the back side, samples 6 and 7 showed a transition to a mixture of sheet and pitting corrosion. Photographs of the front and back of sample 4 are shown in Figure 28.

Figure, 29 shows the results of the gravimetric lests on the hoiler probe samples. All of the samples indicated a linear rate of weight loss over the 240 minute test period. The variation of metal loss with sample temperature is indicated. This data may be interpreted in two ways. If the data poinls are all correct, then a significantly higher rate of material loss exists at temperatures greater than about 673K. This would correspond with the minimum temperature for formation of liquid potassium pyrosulfate from the system $\mathrm{K}_{2} \mathrm{SO}_{4}-\mathrm{SO}_{3}$, which is about $681 \mathrm{~K}\left(408^{\circ} \mathrm{C}\right)$. Or, on the other hand, a linear relationship may exist between material loss rate and temperature, and the departures from this relationship in Figure 29 may be due to experimental inconsistancies.

\section{B. SUPERHEATER TUBE SIMULATION}

Figure 30 shows the appearance of the superheater probe after TP41-13, which ran a total of 36 minutes with 32 minutes on coal and 26 minutes at the control temperature. The probe was taken out of the duct as soon as cooled sufficiently. The outer deposit was thicker on the front side of the probe, about $3.18 \mathrm{~mm}$, and much rougher. Both the thickness and the color, a light gray, were fairly uniform over the length. At the back side, the outer deposit, white to light brown in color, fell away to reveal an underlying layer having a light brown color. The outer layer was about 0.76 $\mathrm{mm}$ thick and the inner layer on the order of $0.01 \mathrm{~mm}$ thick. Spacer 1 was removed with the deposits in place and replaced with a new spacer of the same material, 304 stainless steel. Photographs were taken of the cross-section of the deposits as shown in Figure 31. The front deposit appears to be amorphous and relatively porous. Figure 31 shows the inner 


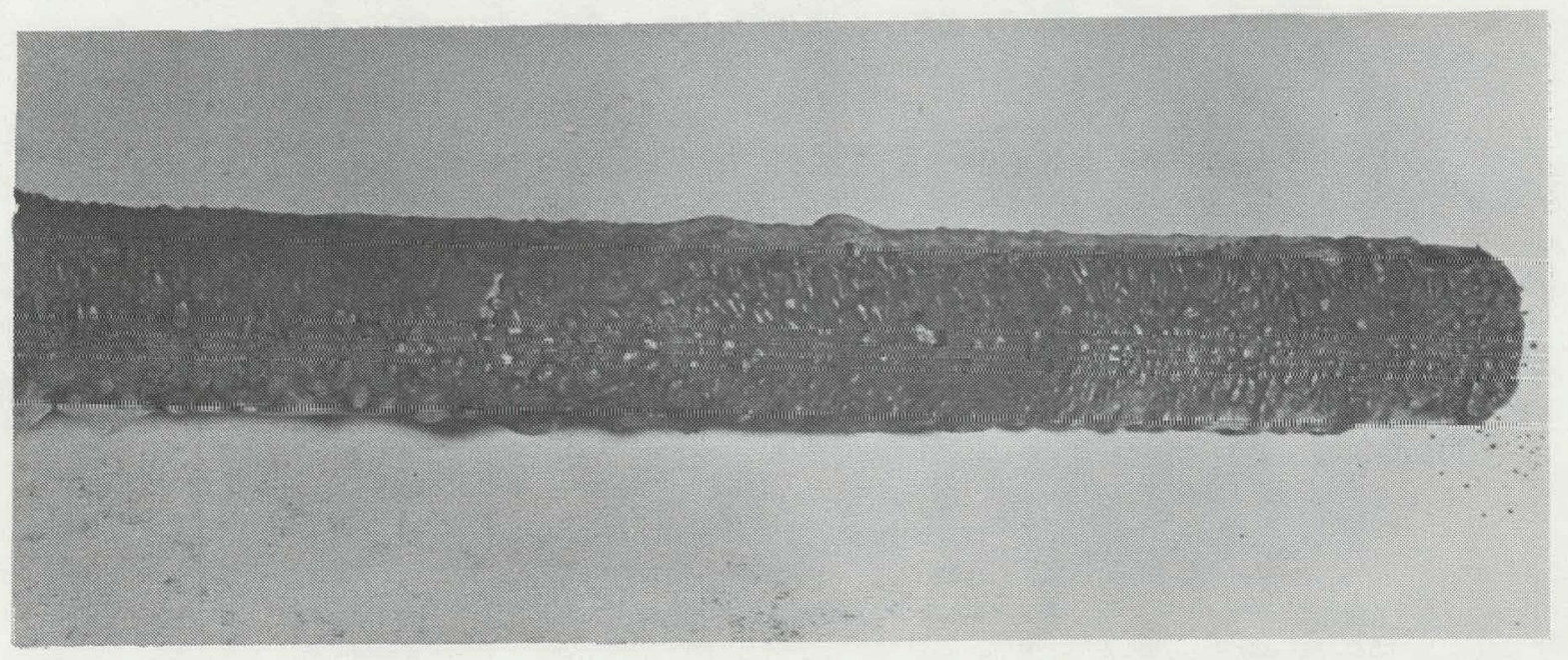

a) Front

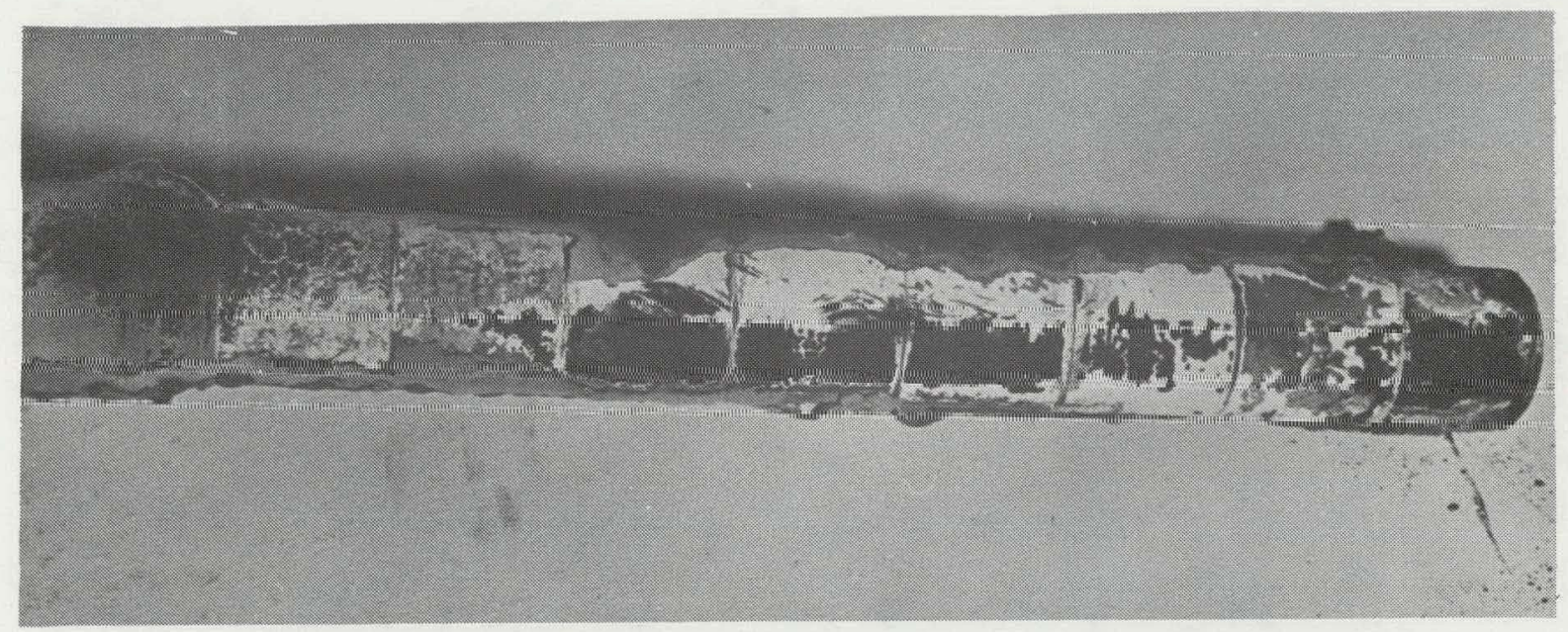

b) Back

Figure 27. Boiler Probe Appearance after Run TP41-14 


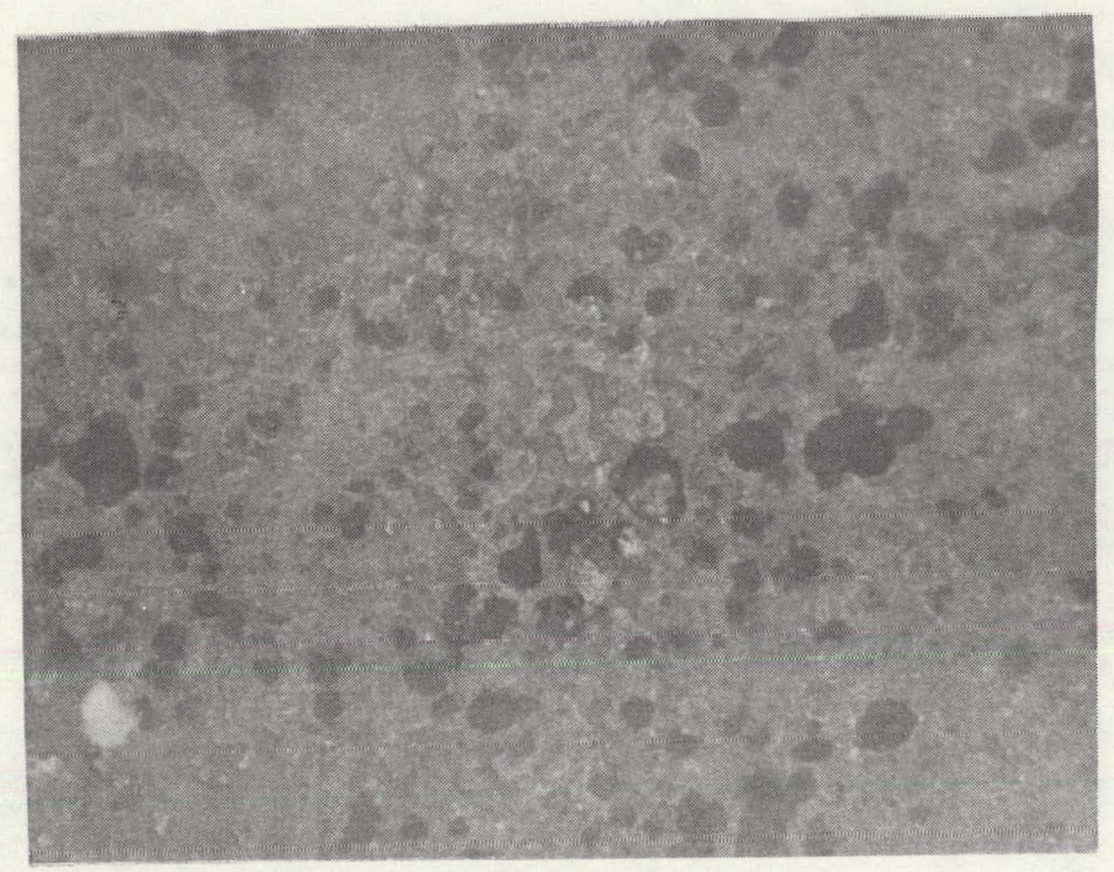

a) Back

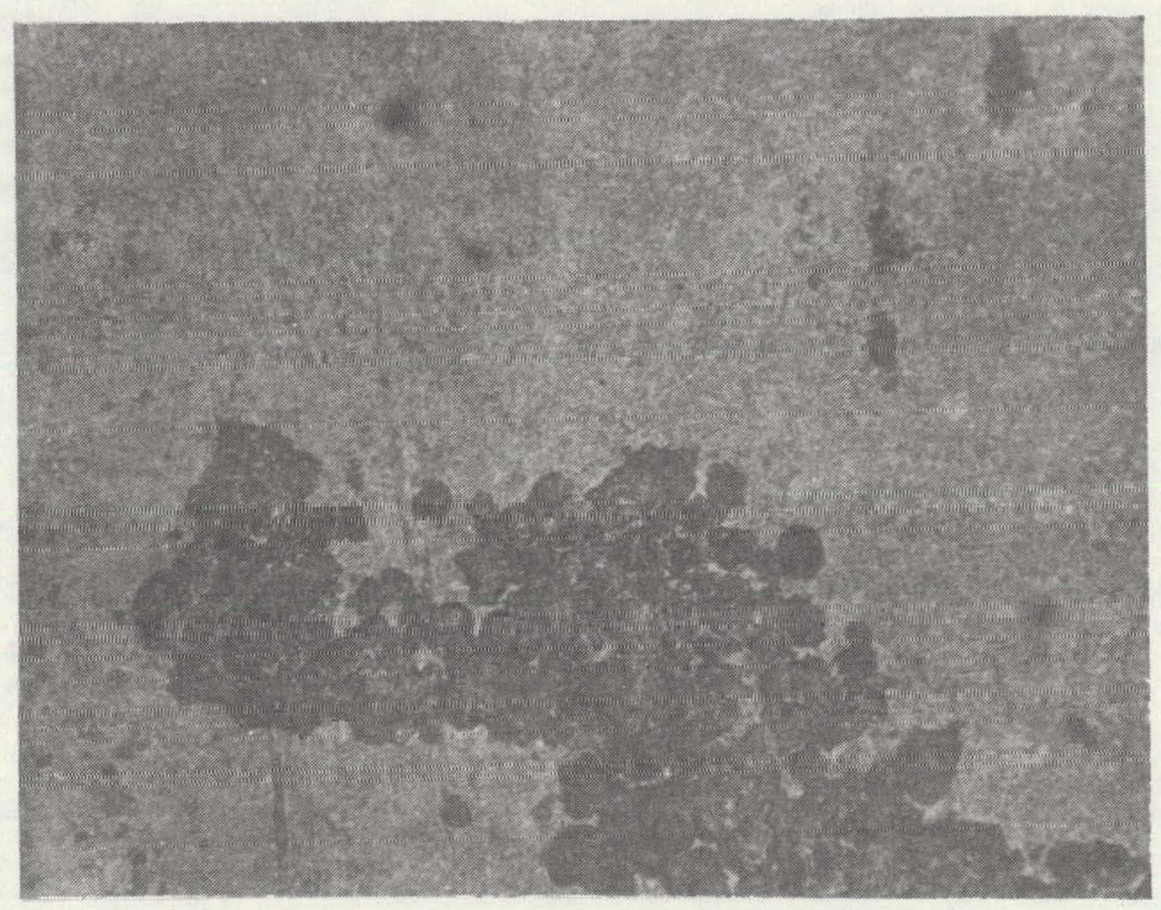

b) Front

Figure 28. Boiler Probe Surface Degradation after TP41-14 and 240 Minutes Accumulated Exposure, 62.5X 


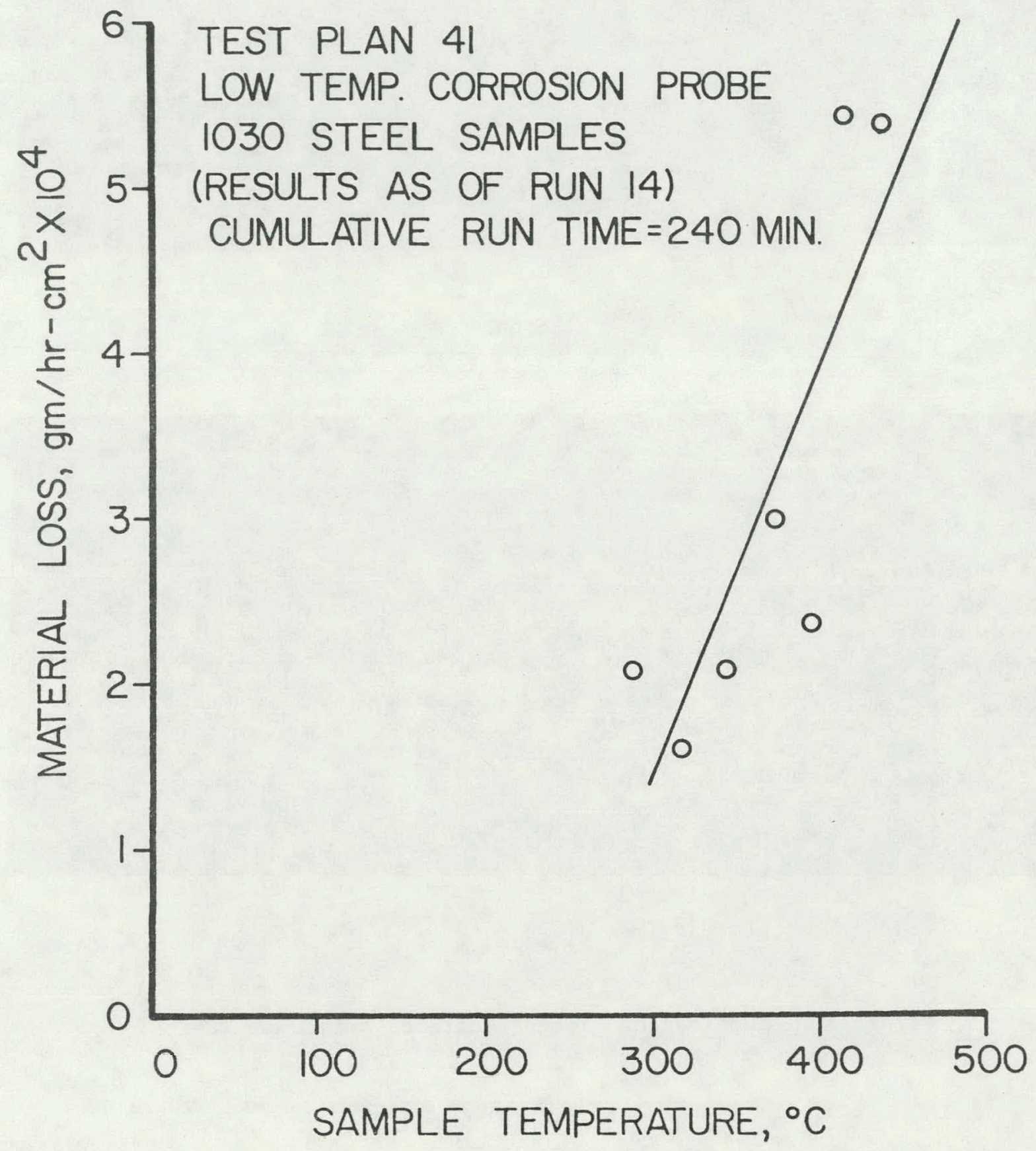

Figure 29. Weight Loss from the Boiler Probe Samples 


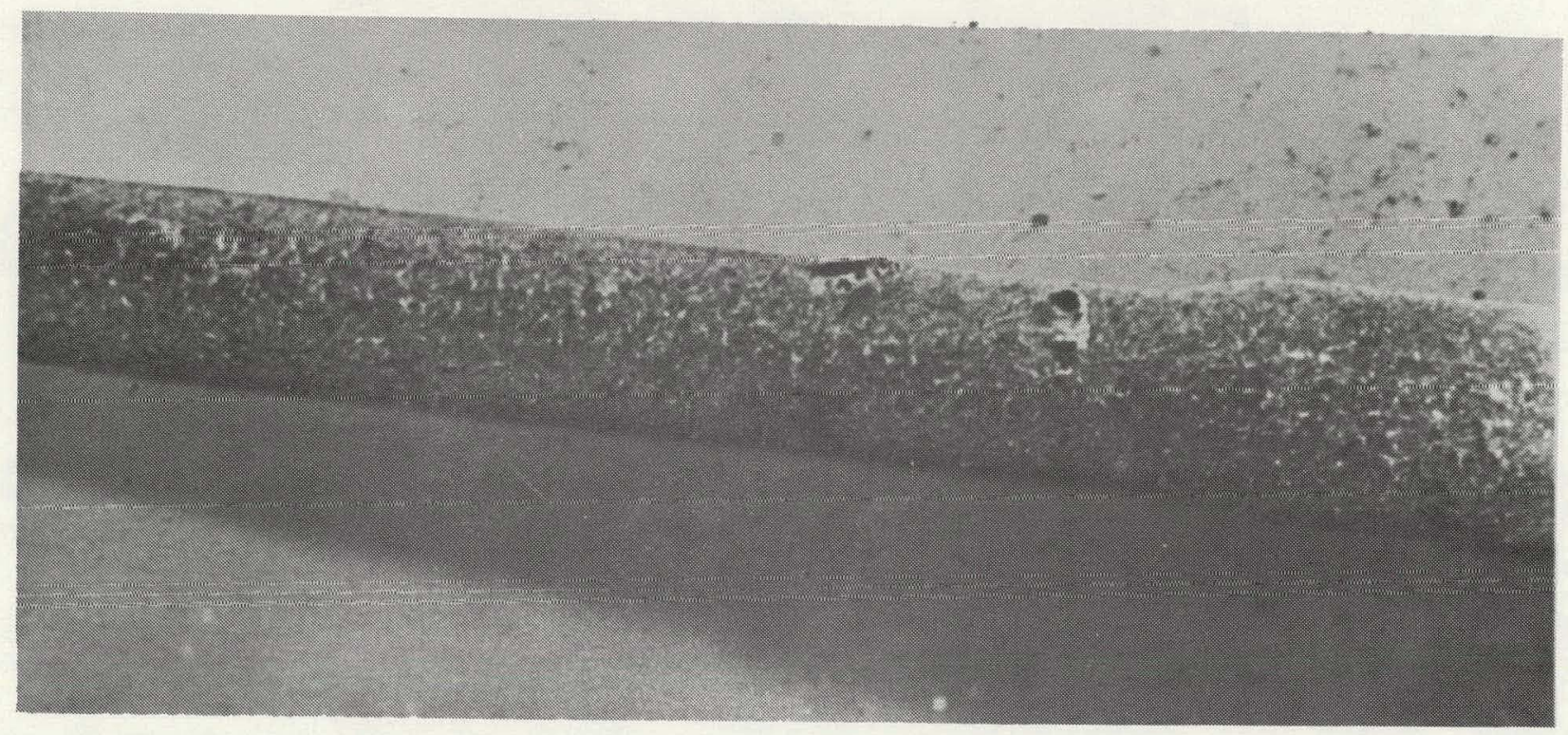

a) Front

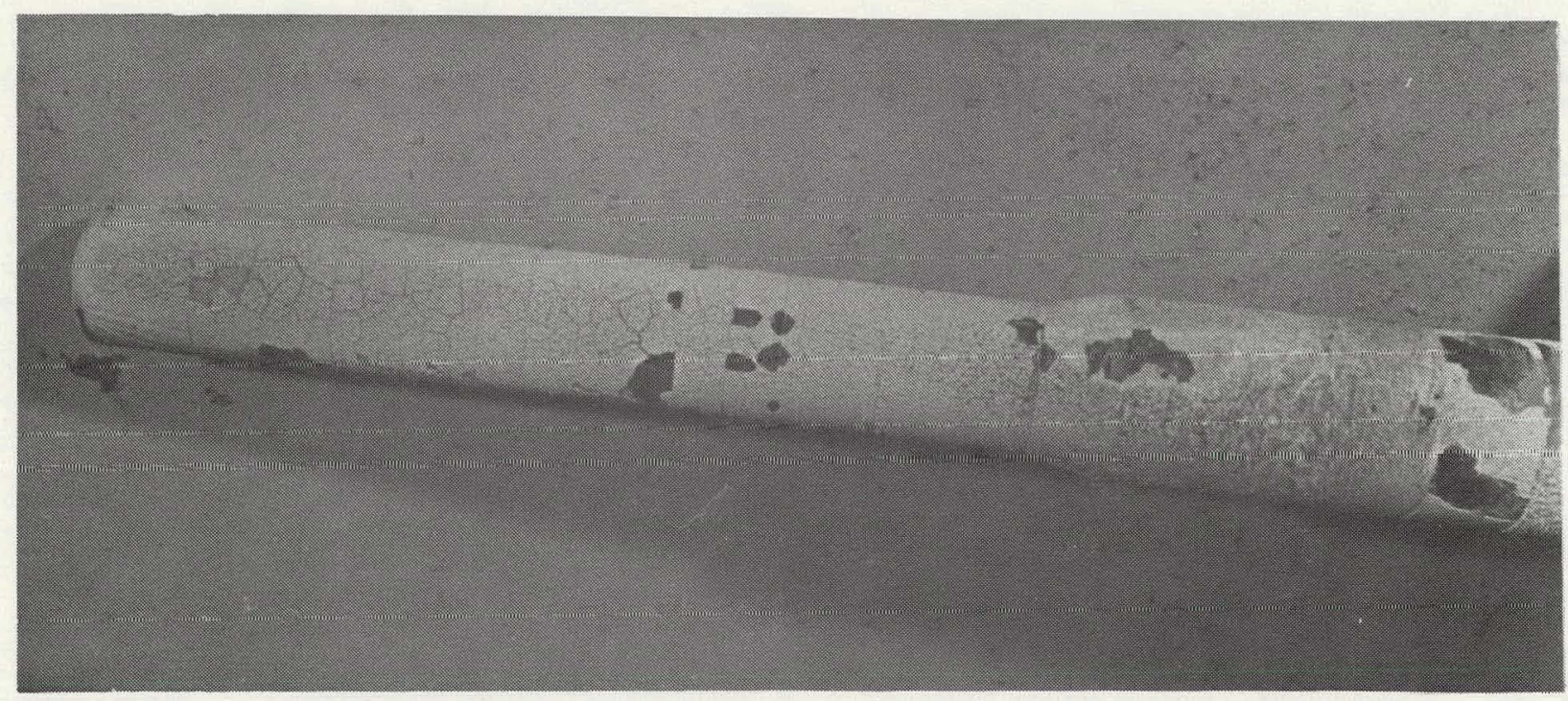

b) Back

Figure 30. Superheater Probe Appearance after Run TP41-13 


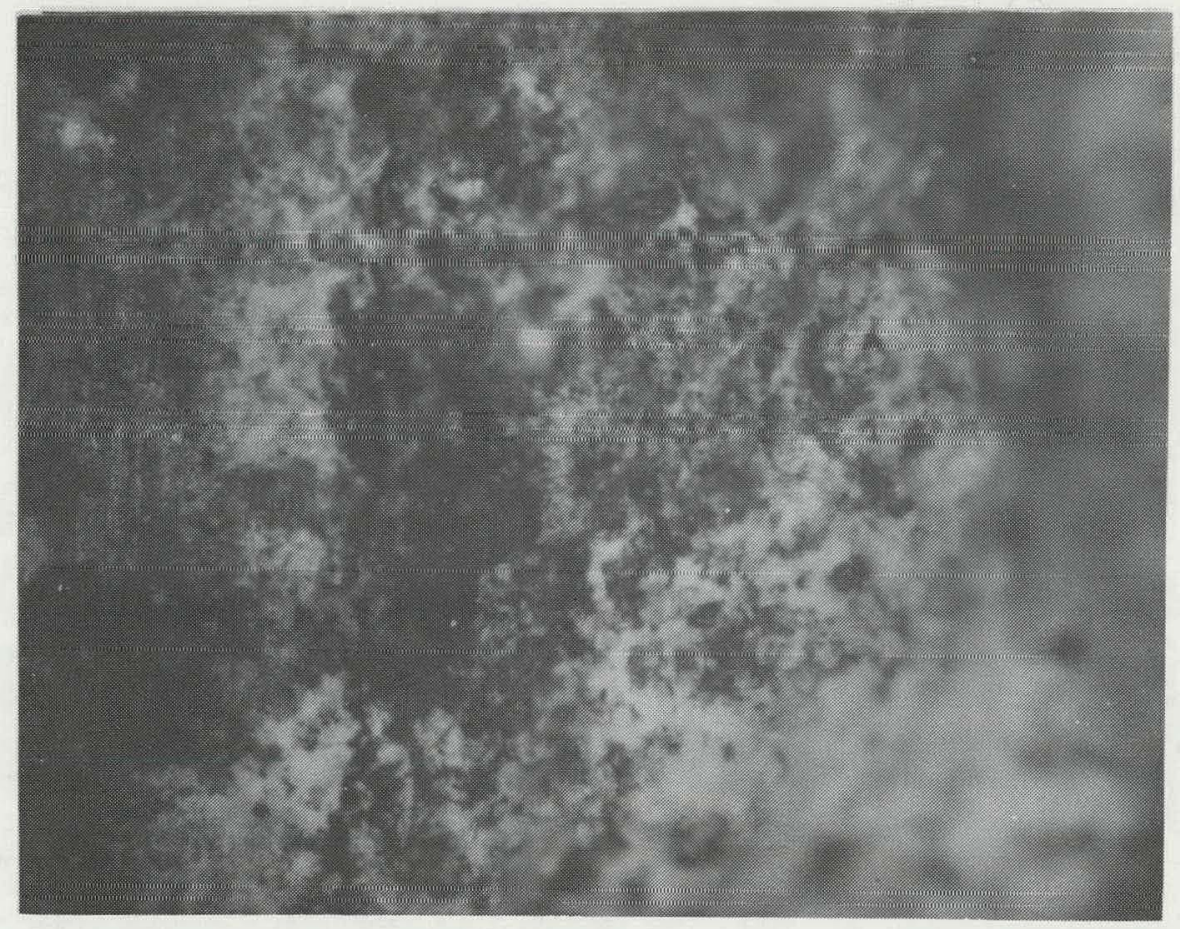

a) Front

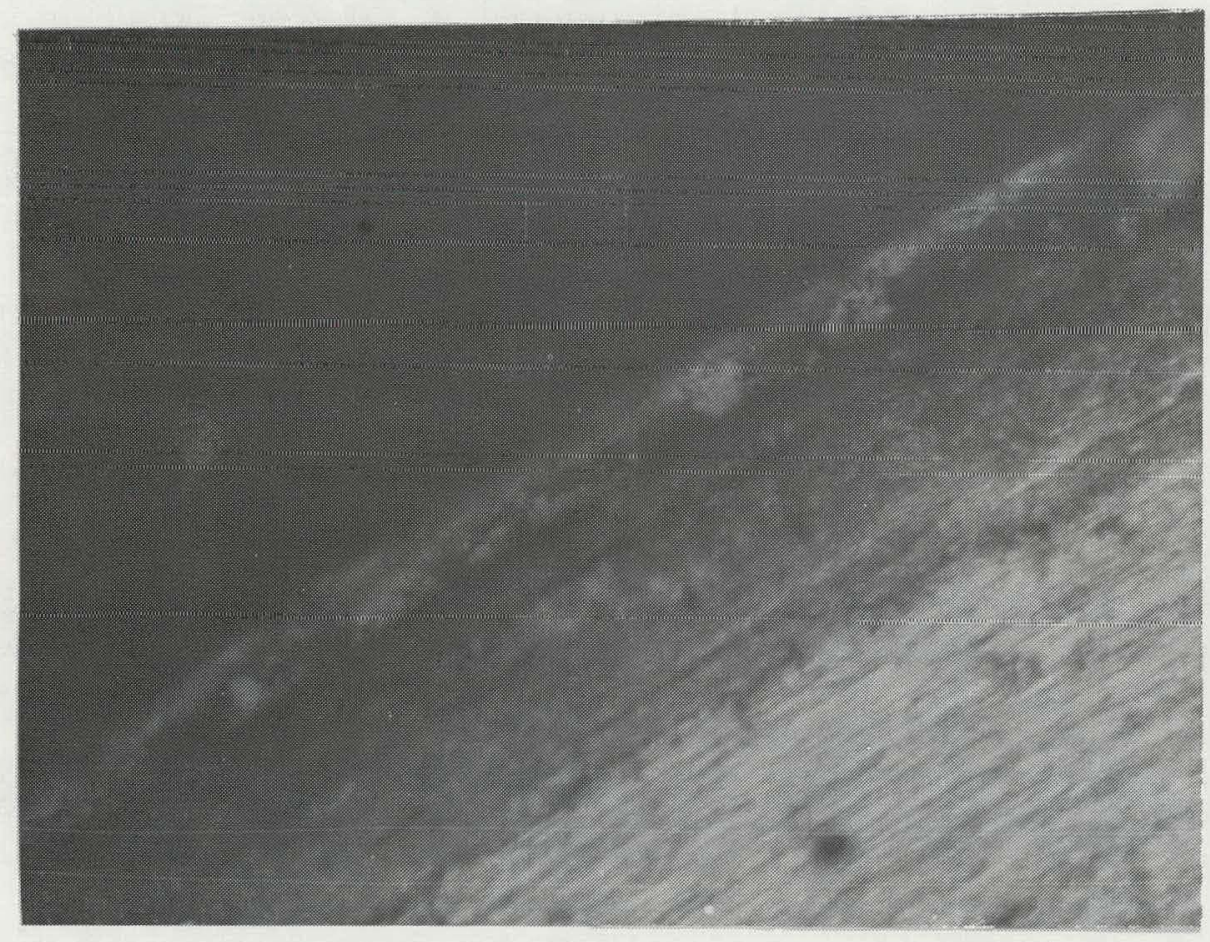

b) Back

Figure 31. Cross-Section Views of Deposits on Superheater Probe Spacer 1 after TP41-13, 62.5X 
part of the deposit on the back side. It appears to have a mostly red color and a uniform thickness.

TP41-14 ran about 54 minutes on coal with 44 minutes at the control temperature. Again the probe was immediately removed. Most of the thick deposit (about $3.18 \mathrm{~mm}$ ) on the front of the probe had fallen off already as seen in Figure 32. This deposit, gray-brown, only remained on Spacer 1, which was a new one. Some of the same looking deposit was on the upstream side of the initial portion of the nonsample area of the probe. There it was about $6.35 \mathrm{~mm}$ thick. On the front of the end cap where the outer material had fallen off was a splotchy rust-red material. Where the outer deposit had fallen away on the remaining samples was a powdery white layer approximatcly $0.13-0.25 \mathrm{~mm}$ thick. The back side of Llie prube appeared about the same over the entire length, the outer layer being about $0.25 \mathrm{~mm}$ thick and light gray with a spheroidal structure. This material was sofl but not extremely powdery. Underneath this was a thin $(0.025-0.05 \mathrm{~mm})$ white to cream colored layer. Beneath was still another layer which was rust red. Toward the sides were a tew streaks of what looked like white ceramic cement. No $\mathrm{H}_{2} \mathrm{~S}$ odor was present.

The first spacer was removed with the deposits in place and the depusit cross-section examined by optical microscopy. On the front side, two distinct layers of deposit material were found as shown in Figure 33a. The inner layer was multicolored with reds, whites, blacks and grays and was quite porous. The outer material was a colorless crystalline deposit with much less porosity. On the back side, the deposit material was entirely white and powdery as seen in Figure 33b. SEM and EDX examination was also made of the same sample deposits cross section. The fluml side inner deposit appearance and elemental analysis is as shown in Figure 34. Potassium and sulfur are the primary constituents indicated. Figure 35 is at about the middle of the outer layer. Again, the same constituents were found. It is interesting to note that no calcium is indicated in the deposit in view of the $6.25 \%$ and $12.5 \% \mathrm{CaCO}_{3}$ fired with the coal in TP41-13 and 14, respectively.

Figure 36 shows more clearly the two deposit layers as well as part of the outer surface in the lower part of the photograph. Figure 37a shows the deposit appearance on the back side of the probe, both the outer material and also the underlying material where the outer had come away. EDX scans of thses two locations are shown in Figure $37 b$ and c. No significant difference exists between the two or between the indicated elemental composition at the front and back of the prohe. It wnuld appear likely that the deposit is mostly potassium sulfate with a small amount of ash.

The deposits were removed from the superheater probe and stored, and the samples were washed with water. The $\mathrm{pH}$ of the wash water was found to be between 6 and 7 , i.f. nentral, indicating the presence of relatively little $\mathrm{K}_{2} \mathrm{CO}_{3}$ in the deposit since it would form a basic aqueous solution. Figure 38 shows the appearance of the samples. All samples had a reddish appearance particularly at the rear and particularly the carbon and low alloy steel samples. The leading edge of all samples was the most degraded, having mottled or speckled colors of light and dark brown. The sides were least damaged, there being a narrow band at $\pm 60^{\circ}$ that was significantly less corroded. 


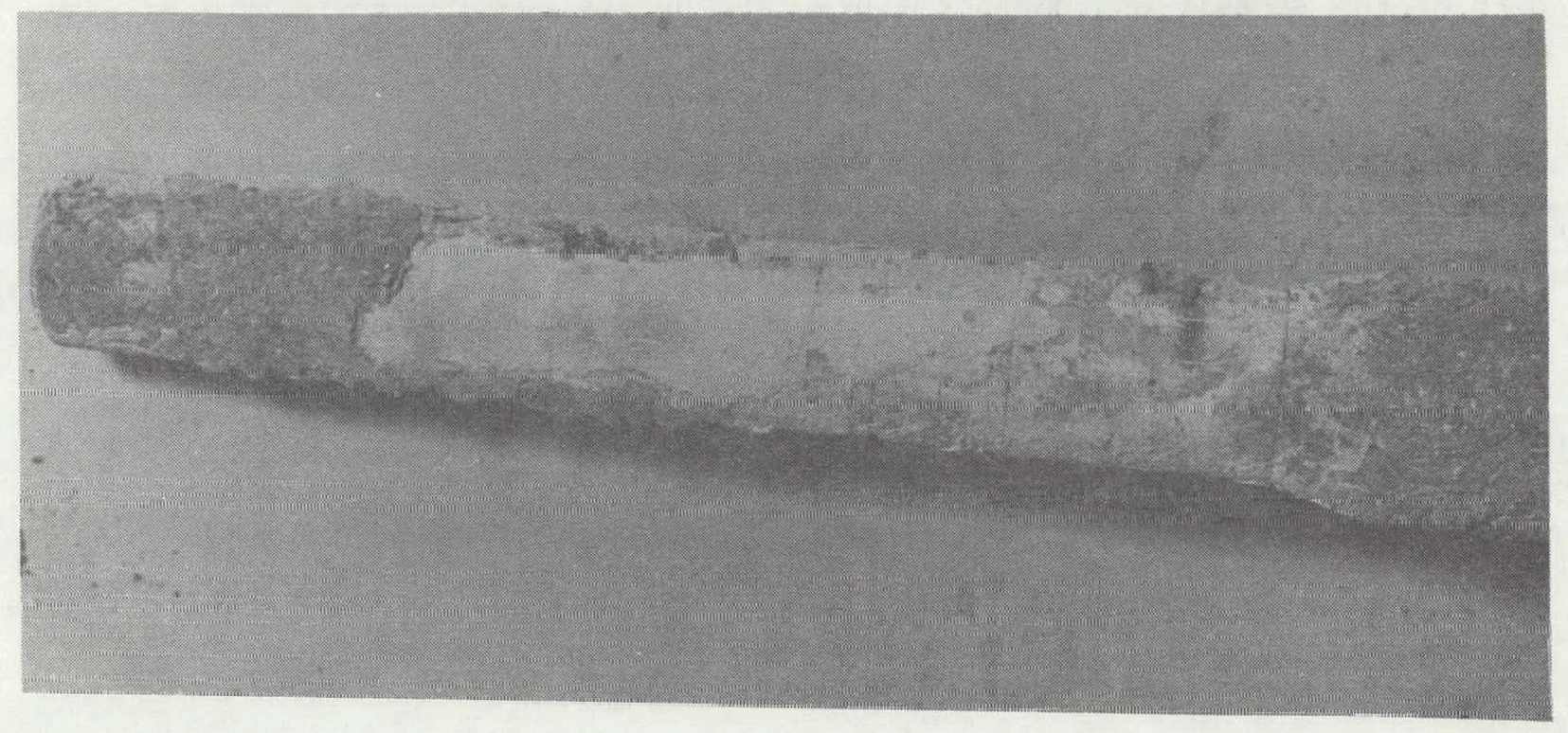

a) Front

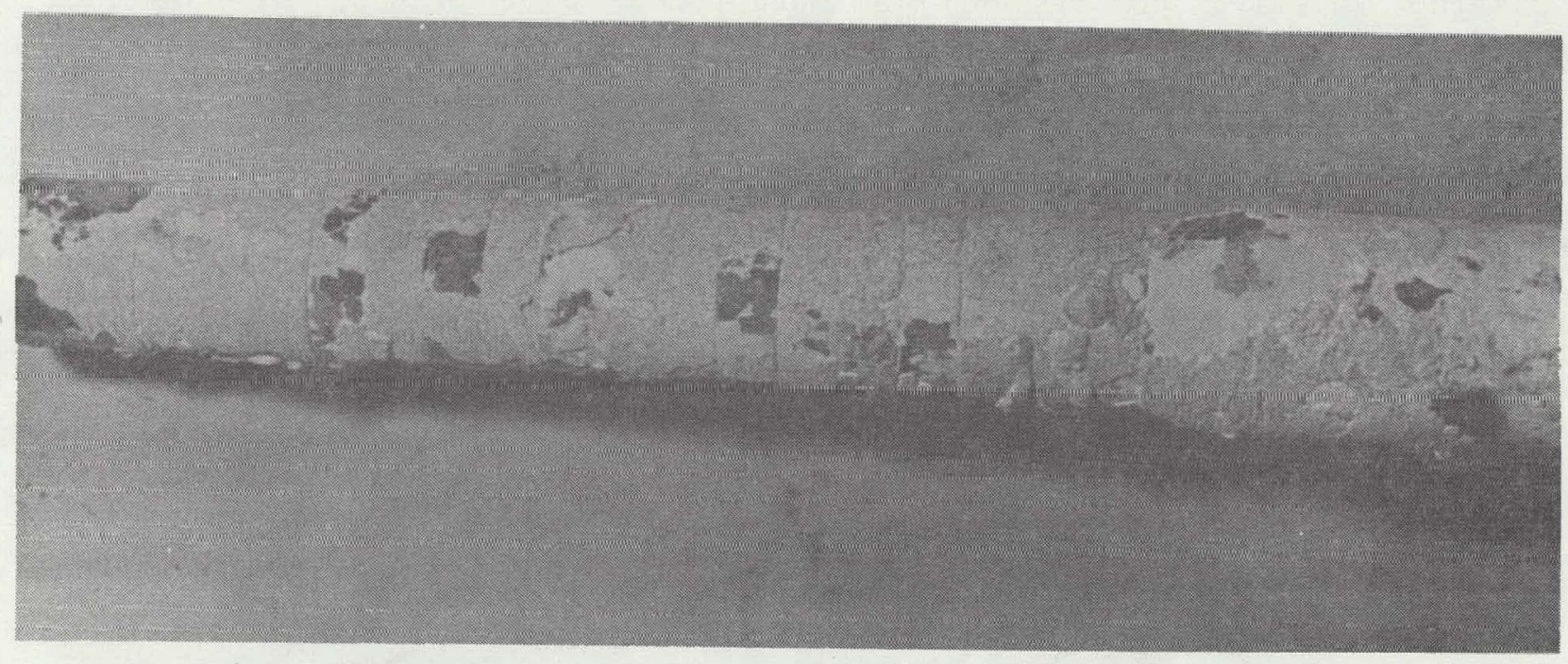

b) Back

Figure 32. Superheater Probe Appearance after Run TP41-14 


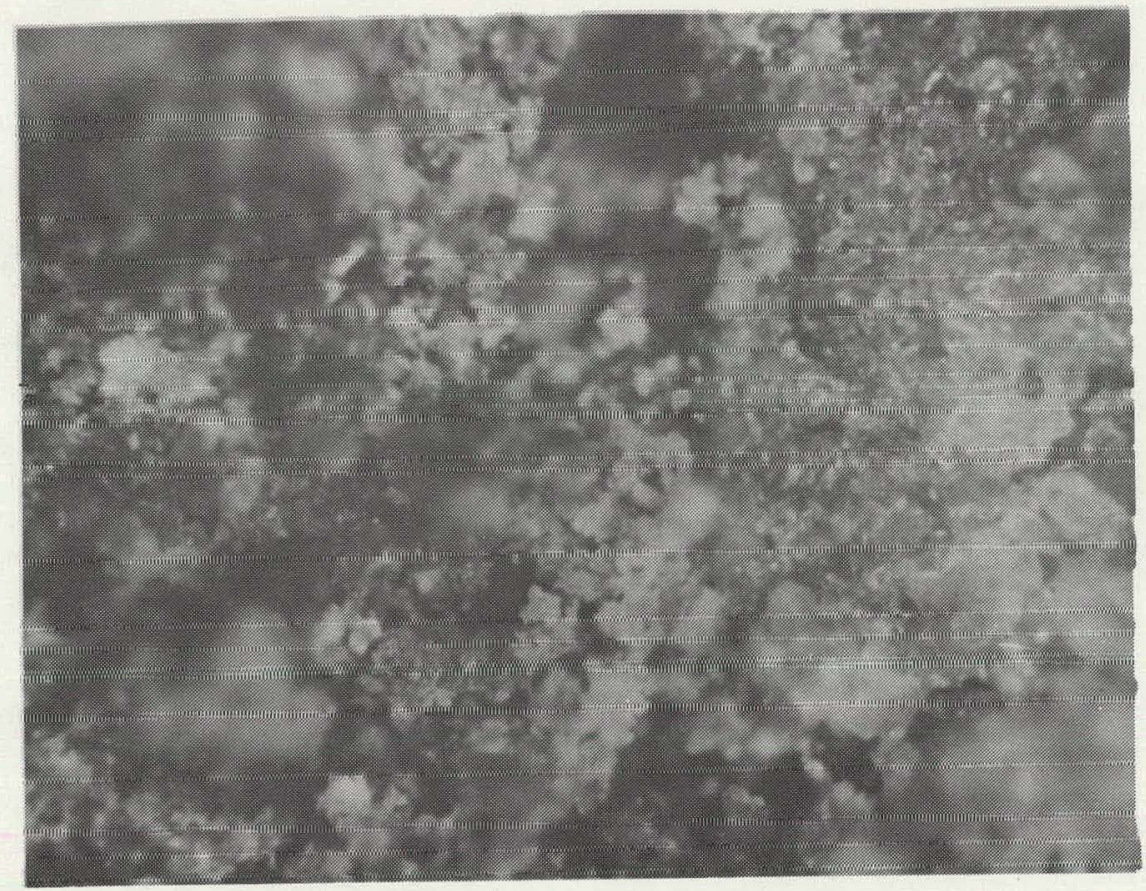

Inner Deposit / Outer Deposit

a) Front

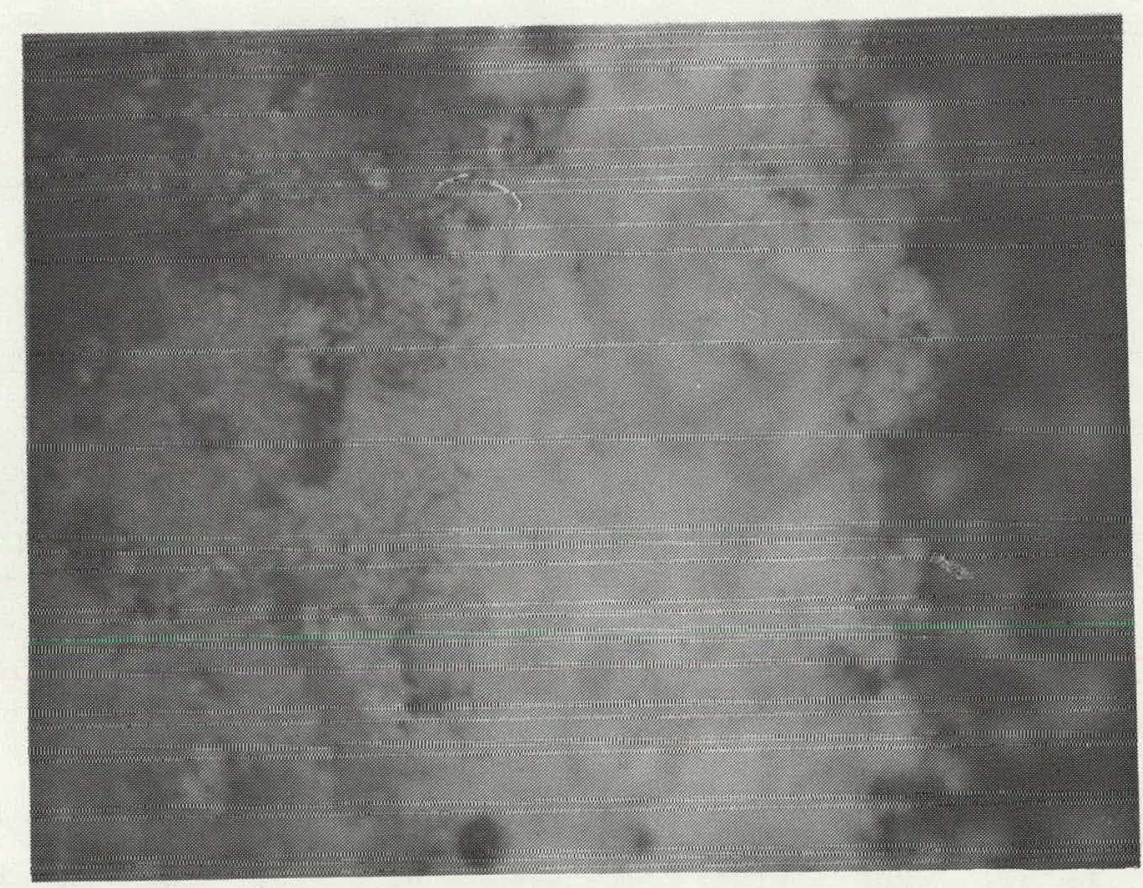

Metal / Deposit

b) Back

Figure 33. Deposits on Superheater Spacer 1 after TP41-14, 62.5X 

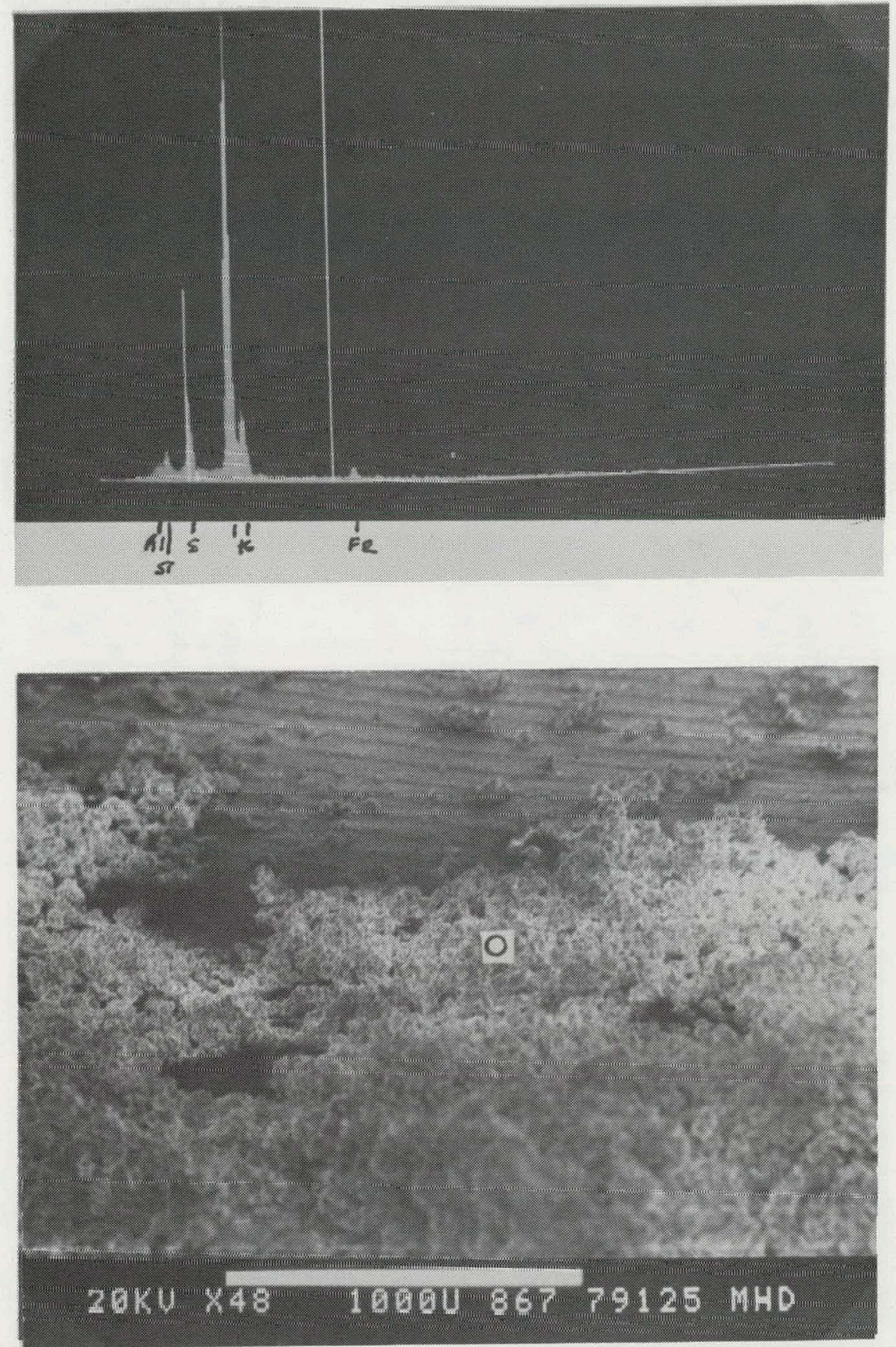

Figure 34. Inner Part of Front Deposit on Superheater Probe Spacer 1 after TP41-14 

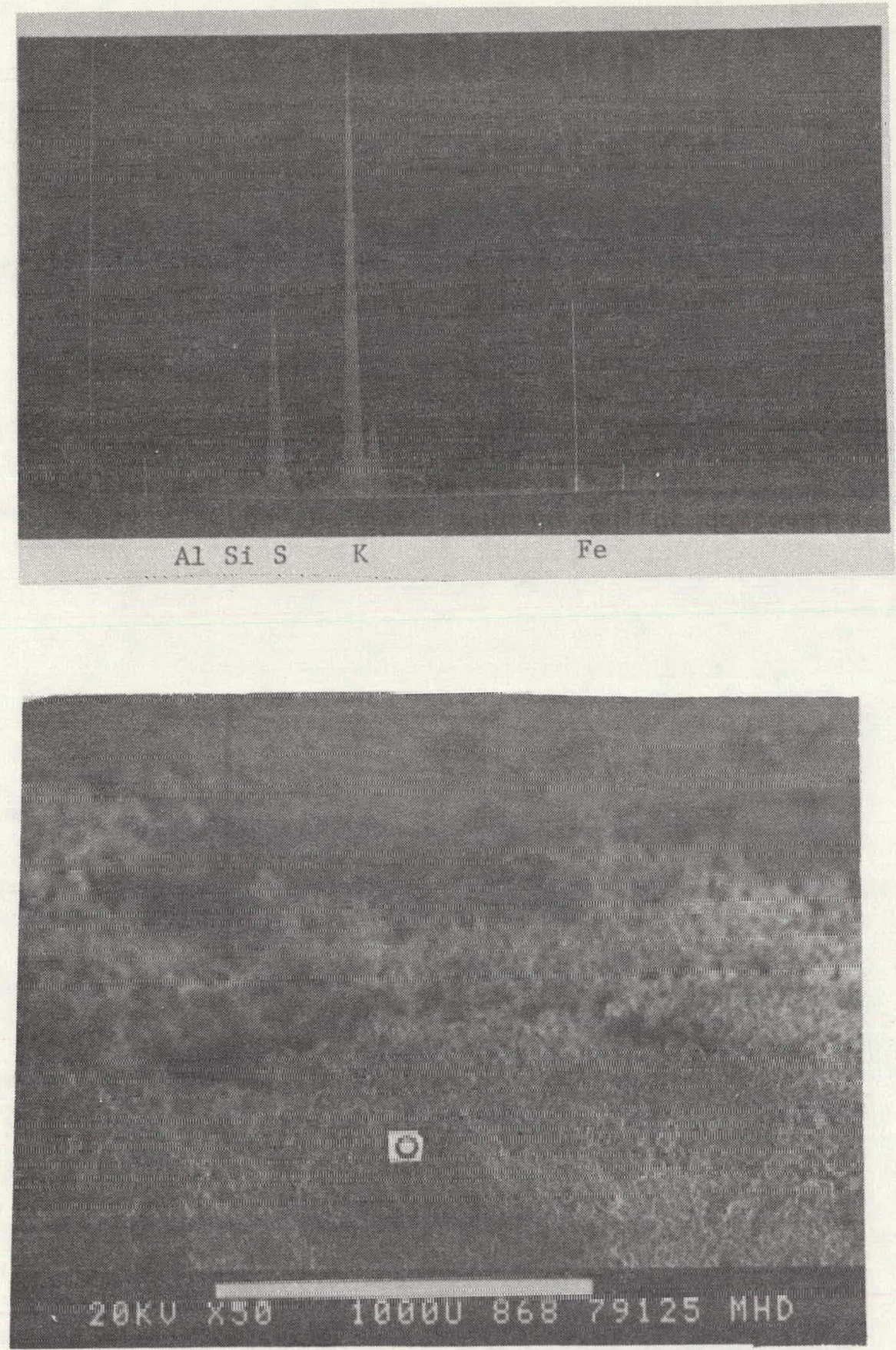

Figure 35. Outer Part of Front Deposit on Superheater Probe Spacer 1 after TP41-14 


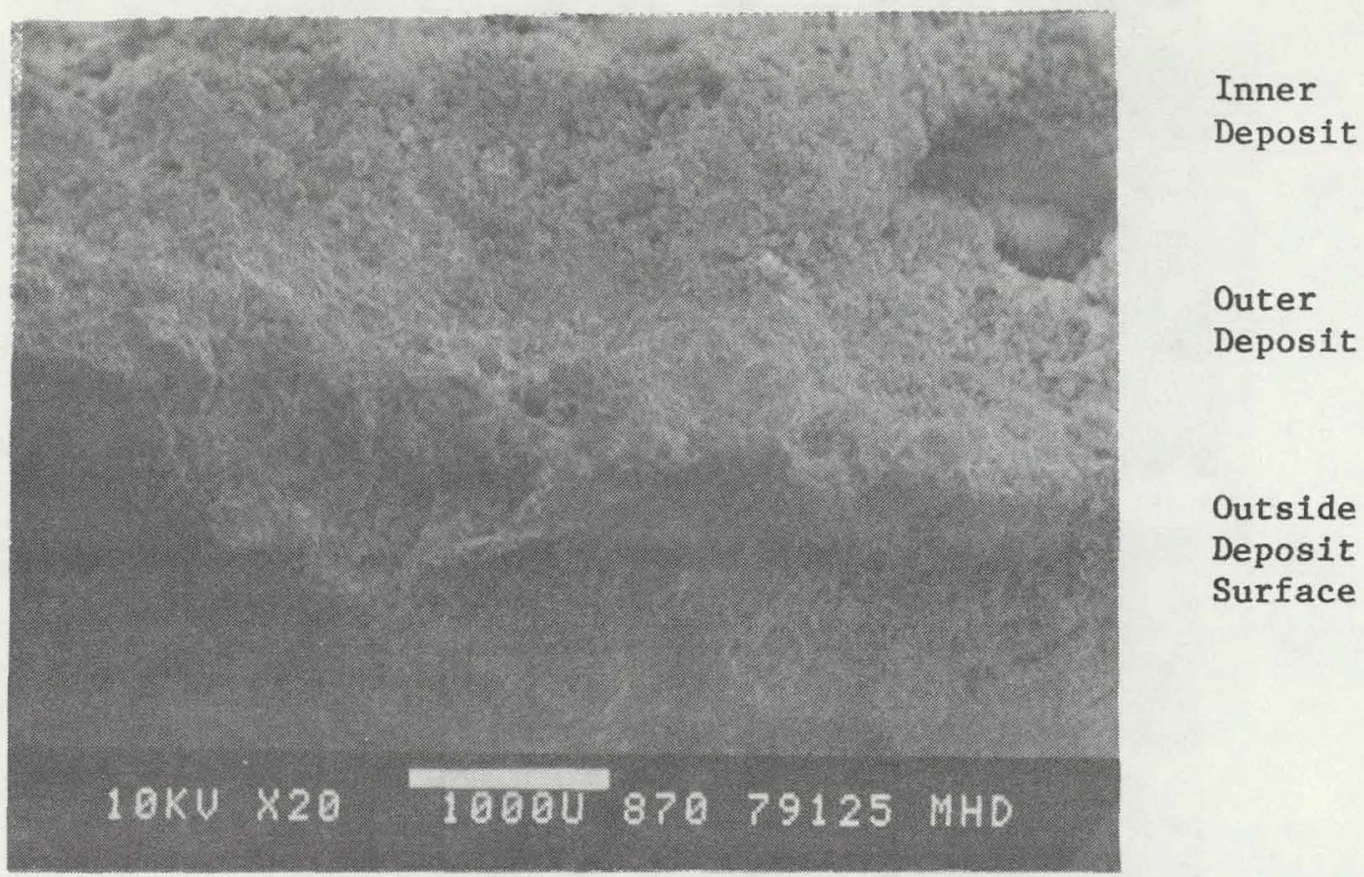

Figure 36. Cross-Section of Ash/Seed Deposit on Superheater Probe Spacer 1 after TP41-14

Al1 samples were found to have a thin scale covering the surface as shown in Figure 39 where part of it had chipped away revealing the base metal. The nature of the scale seemed to be the same on all samples, varying only in thickness and extent of surface coverage. The scale appeared to have two components, an outer gray layer and an underlying red layer. The red layer seemed to cover all the metal surfaces of the low alloy samples and was present wherever there was any scale on the stainless steel samples. On the back side of the low alloy samples, this red scale predominated, its appearance being shown in Figure 40. Like all of the scale, it had a porous texture that gave it the appearance of a red carpet. The amount of gray uverlying the red scale seemed to increase with the severity of the corrosive attack being the greatest at the front face, as seen in Figure 41 at $125 \mathrm{X}$ and $500 \mathrm{X}$ for the low alloy steels. Of the stainless steels, Type 310 showed the least attack, as would be expected since it is highest alloyed. Figure 42 shows the front appearance of the 310 SS sample. The light areas are bare metal. Considerable care must be taken in comparing among the the different samples due to the variation in temperature along the length of the probe.

The sample gravimetric results are given in Figure 43. It is readily apparent that an appreciable disparity in scale buildup, 1.e., corrosion resistance, exists between the low alloy steels and the stainless steels. From these results it is seen that Type 310 is the most resistant to the corrosion. However, Type 304, which was at a higher temperature, did not perform appreciably worse and is much more economical. 

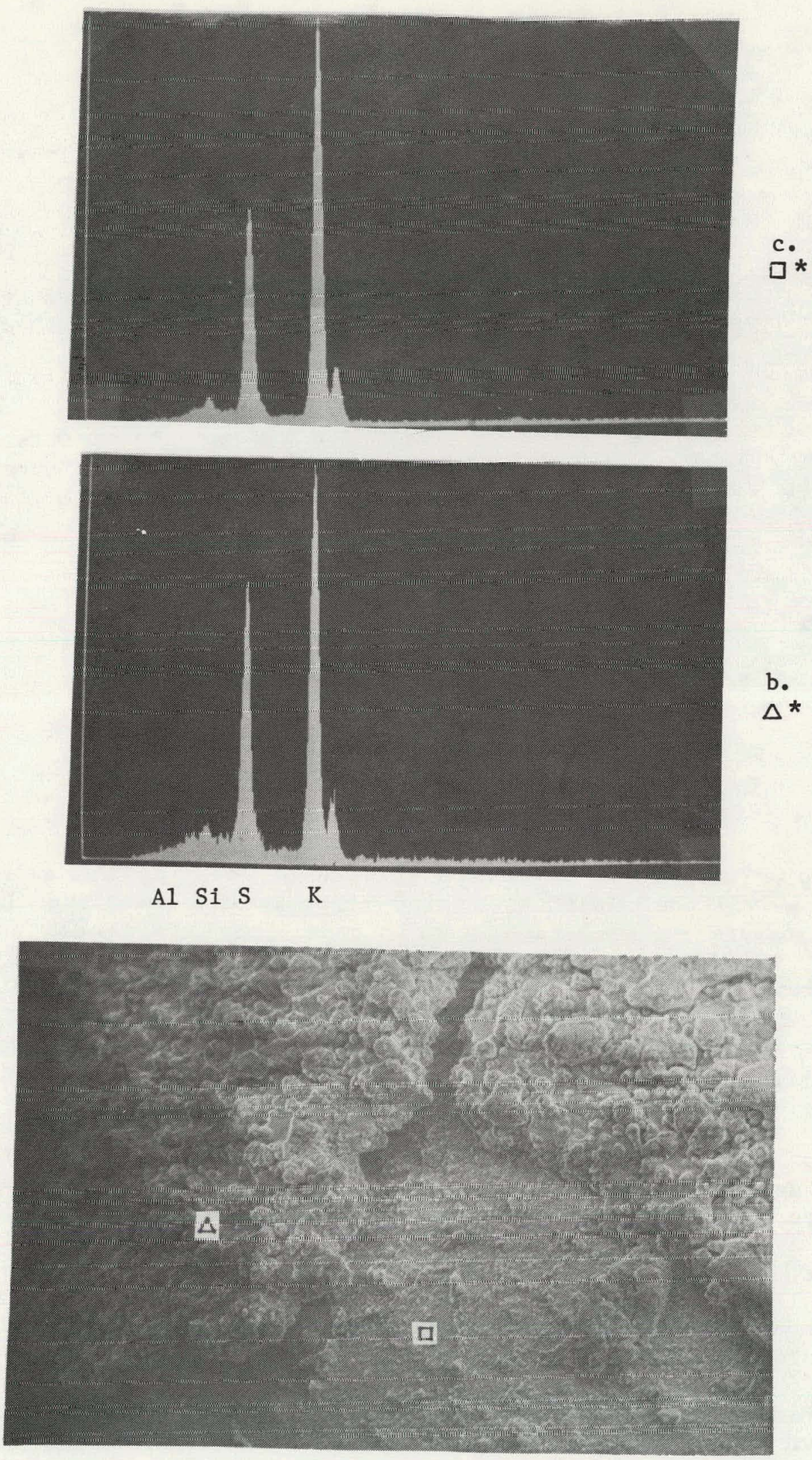

a. $20 \mathrm{x}$

Figure 37. Outer and Inner Deposits on Back of Superheater Probe Spacer 1 after TP41-14

(* Location of EDAX Scan) 


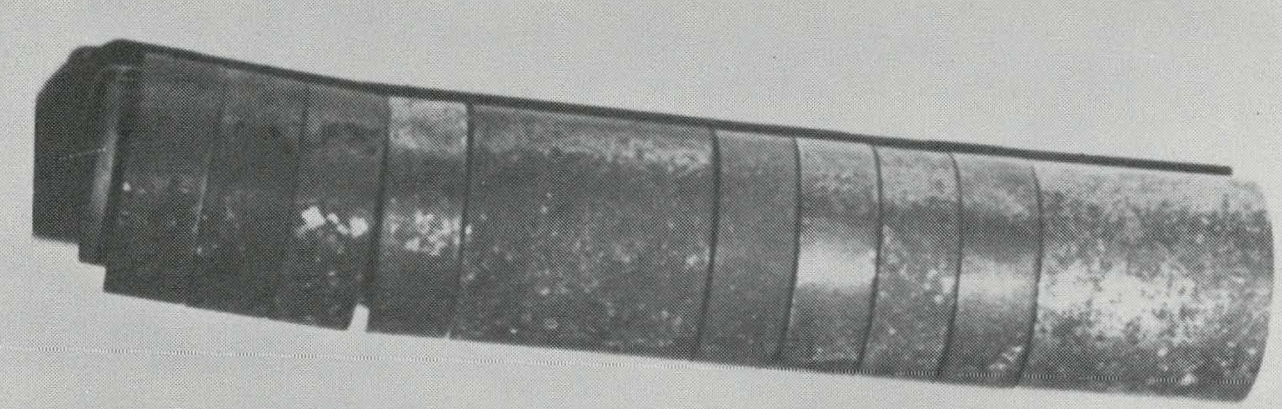

a) Front

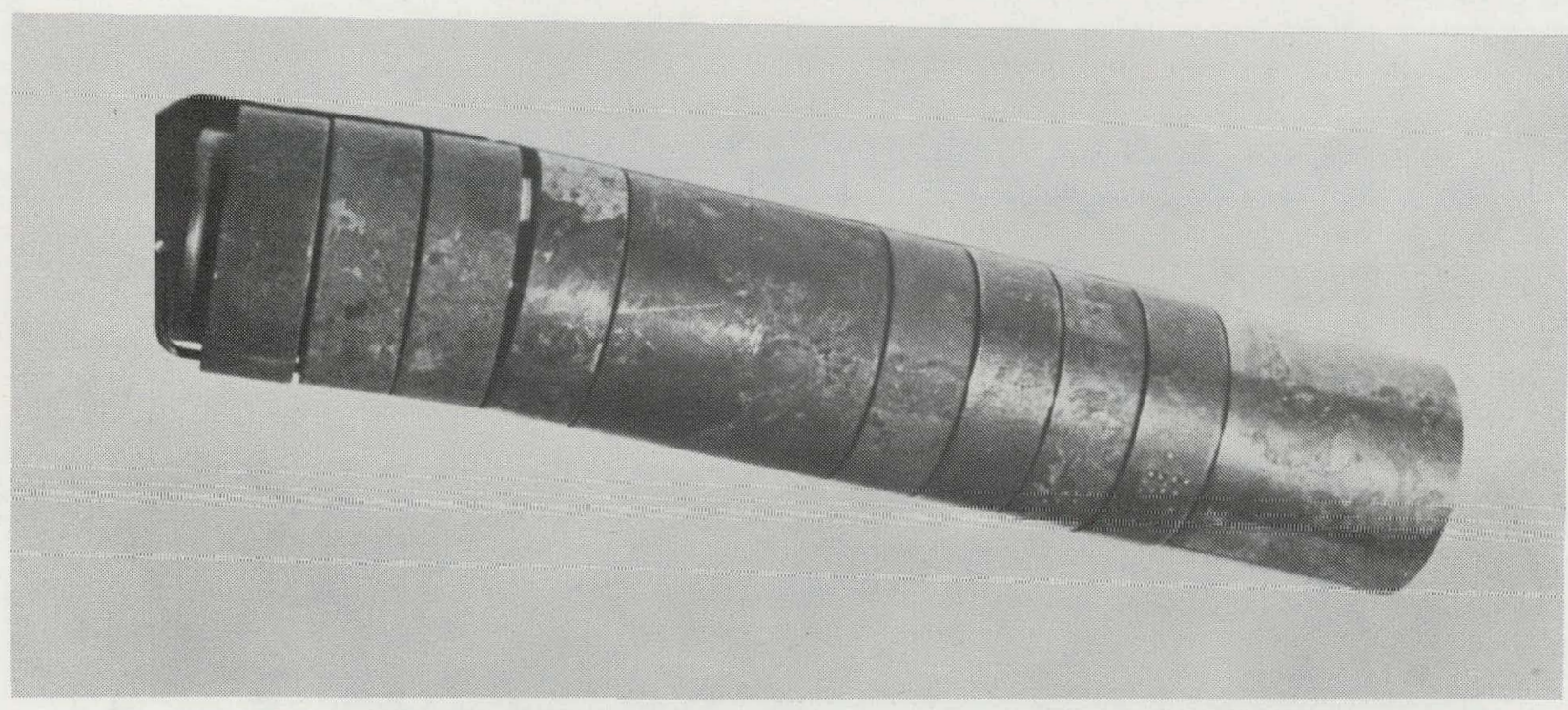

b) Back

Figure 38. Cleaned Superheater Probc Samples after Run TP41-14 


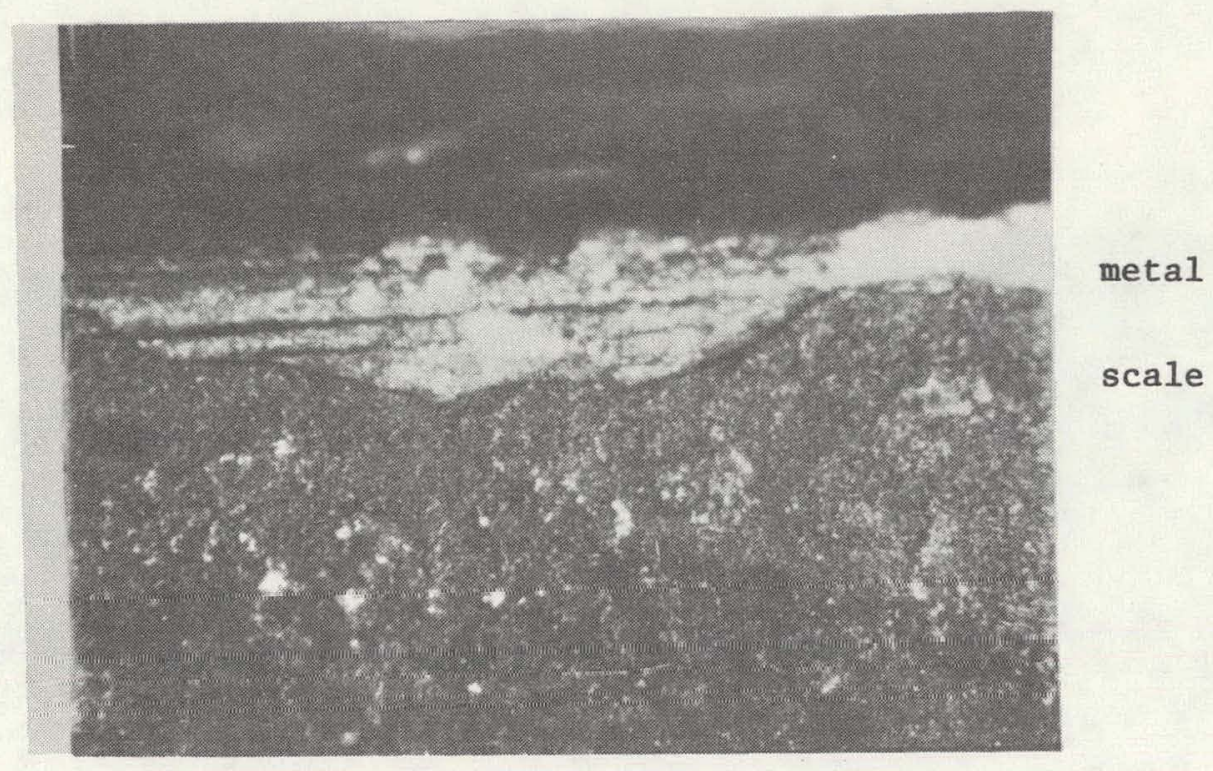

Figure 39. Surface Scale on Carbon Steel Superheater Probe Sample after Run TP41-14

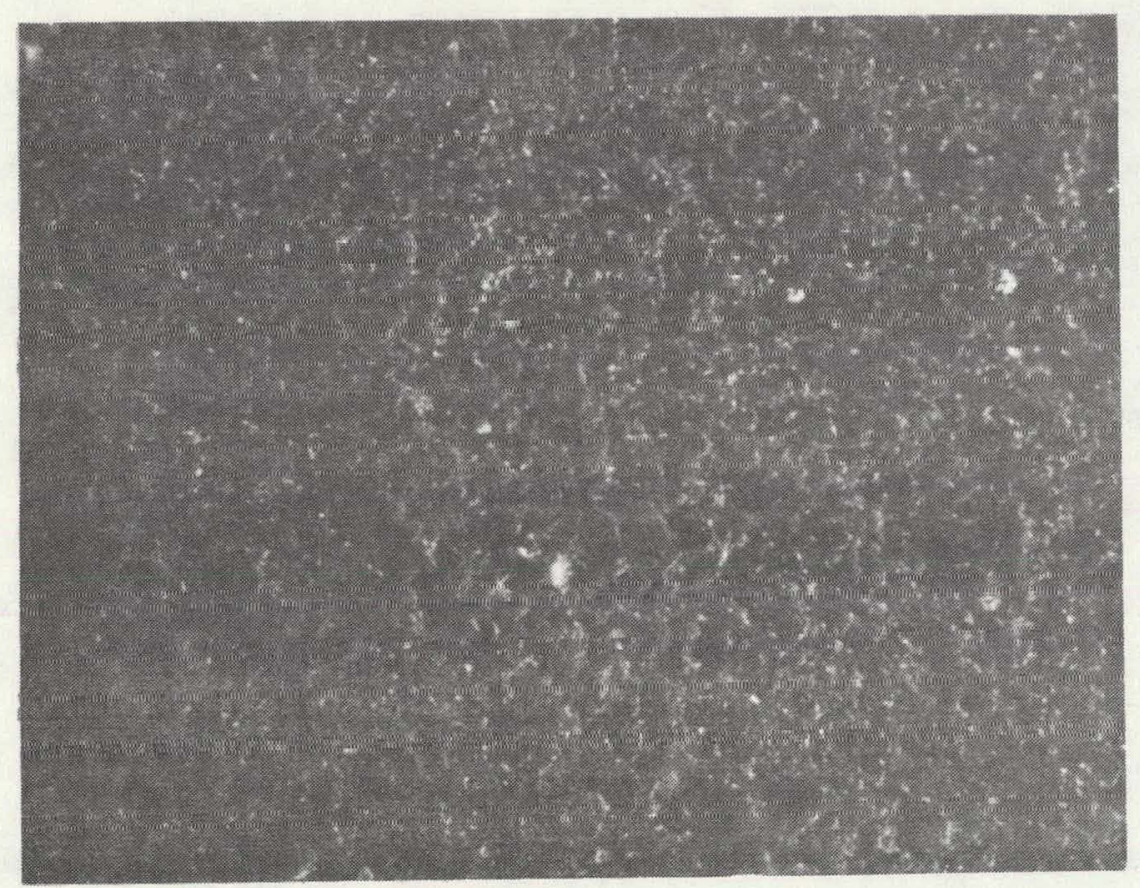

Figure 40. Micrograph Showing Scale on Back of Croloy 9 Superheater Probe Sample after TP41-14, 500X 


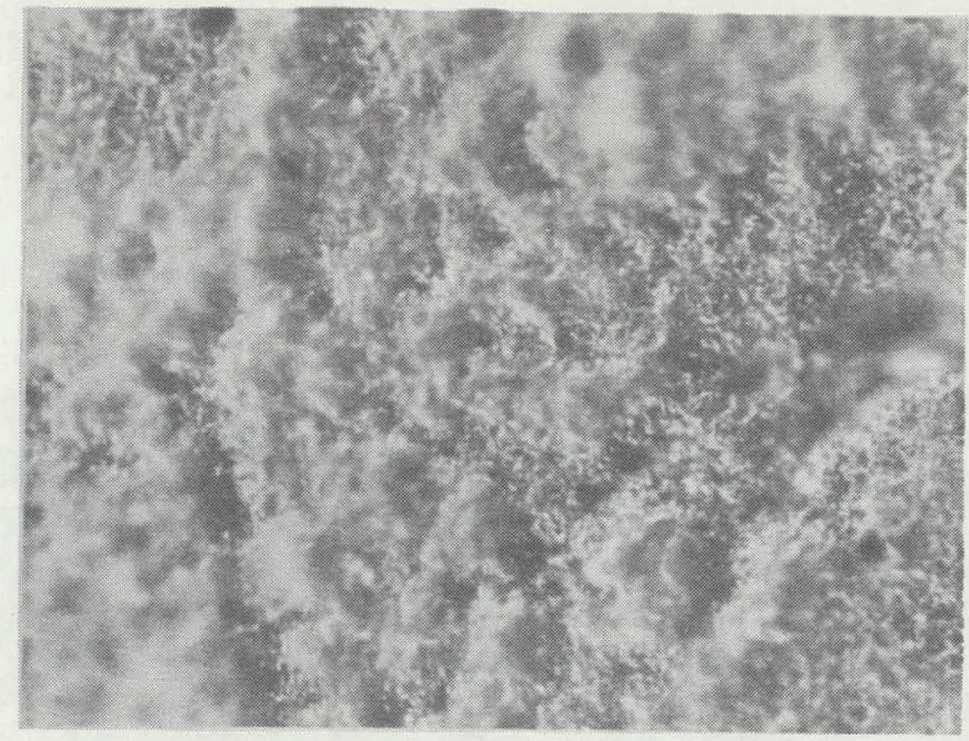

1030 Carbon Steel, $500 \mathrm{x}$

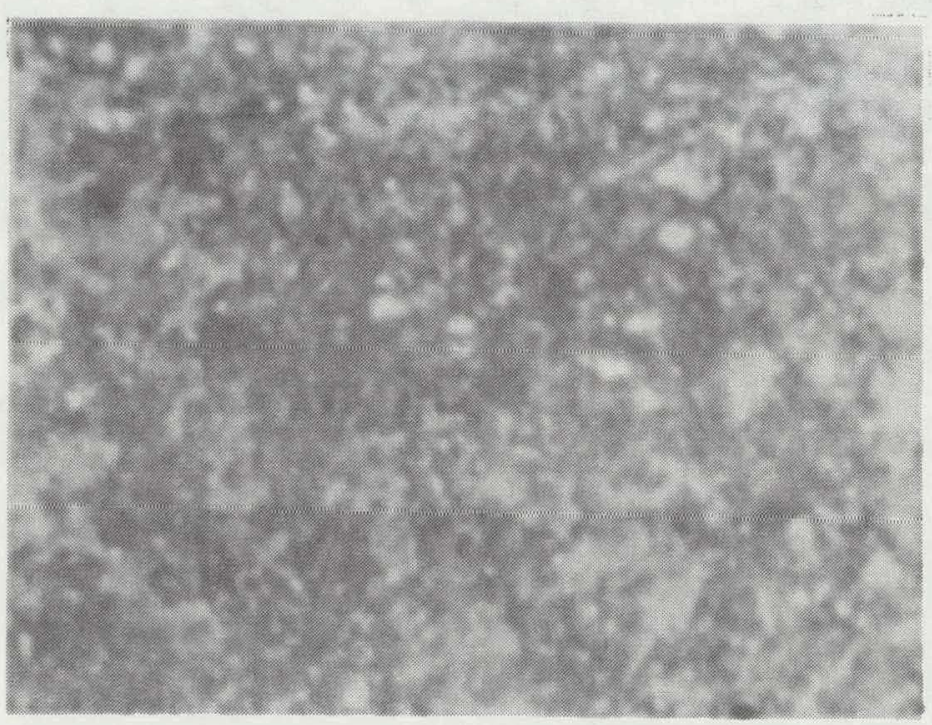

2-1/4 Croloy, 125x

Figure 41. Scale on Front of Superheater Probe Samples after TP41-14 


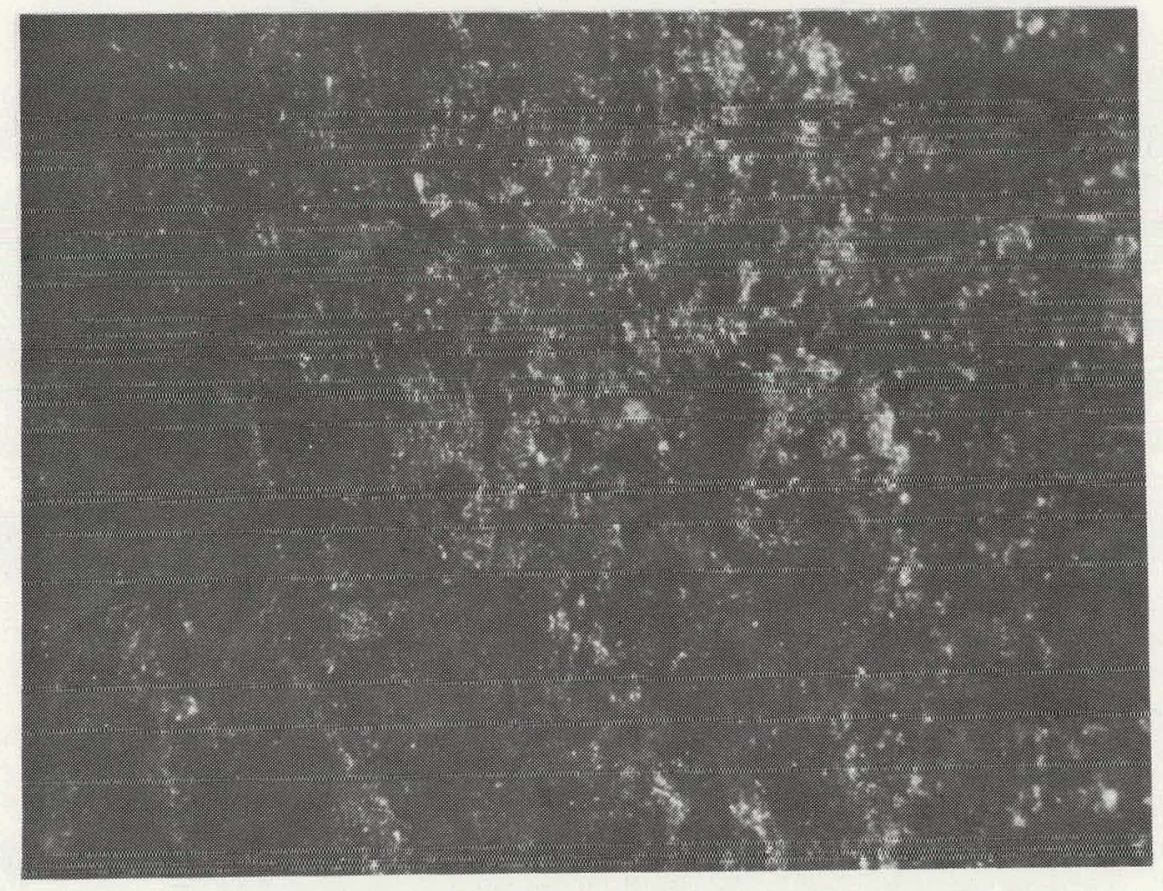

F1gure 42. Front Surface of 310 Stainless Steel Superheater Probe Sample after TP41-14, 62.5X 


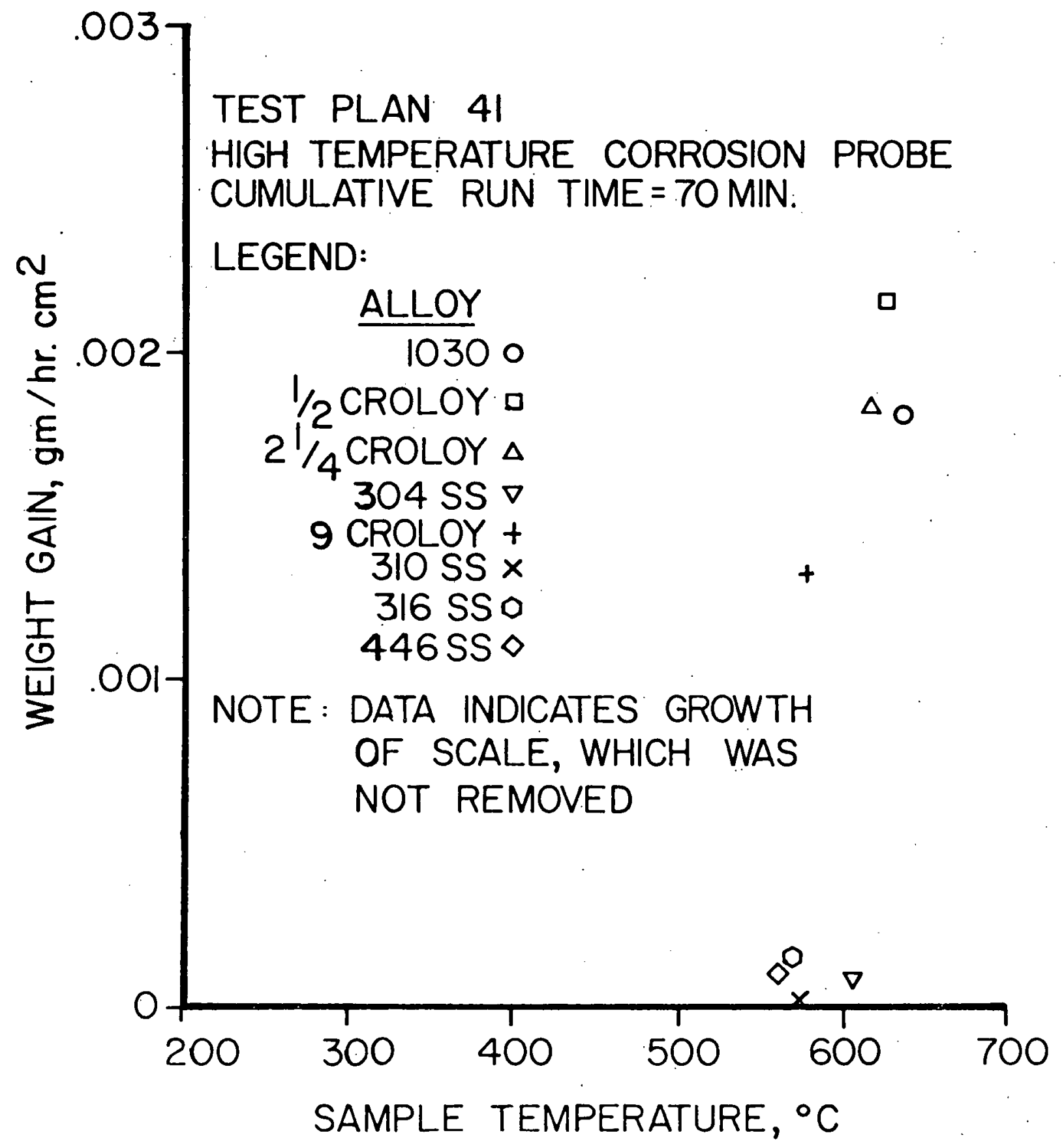

Figure 43. Scale Bulldup on Superheater Probe Samples 


\section{DISCUSSION}

\section{A. BOILER CORROSION}

Attack on boiler tubes operated in a reducing atmosphere occurs principally by sulfidation. The mechanism by which this occurs in an MHD environment is as yet unknown. Due to the numerous constituents and nonequilibrium conditions present, determination of these mechanisms is quite difficult.

However, due to the lack of excess oxygen to form $\mathrm{SO}_{3}$, which is necessary for formation of corrosive alkali pyrosulfates and trisulfates or iron sulfates, the most 1 ikely merhanism is gasoous attaok by $H_{L} S$. Even at a stolchlometry of 0.85 the most abundant sulfur compound is expected to be $\mathrm{SO}_{2}$ above about $1400 \mathrm{~K}$, as shown in Figure 44.15 In the CFFF, the

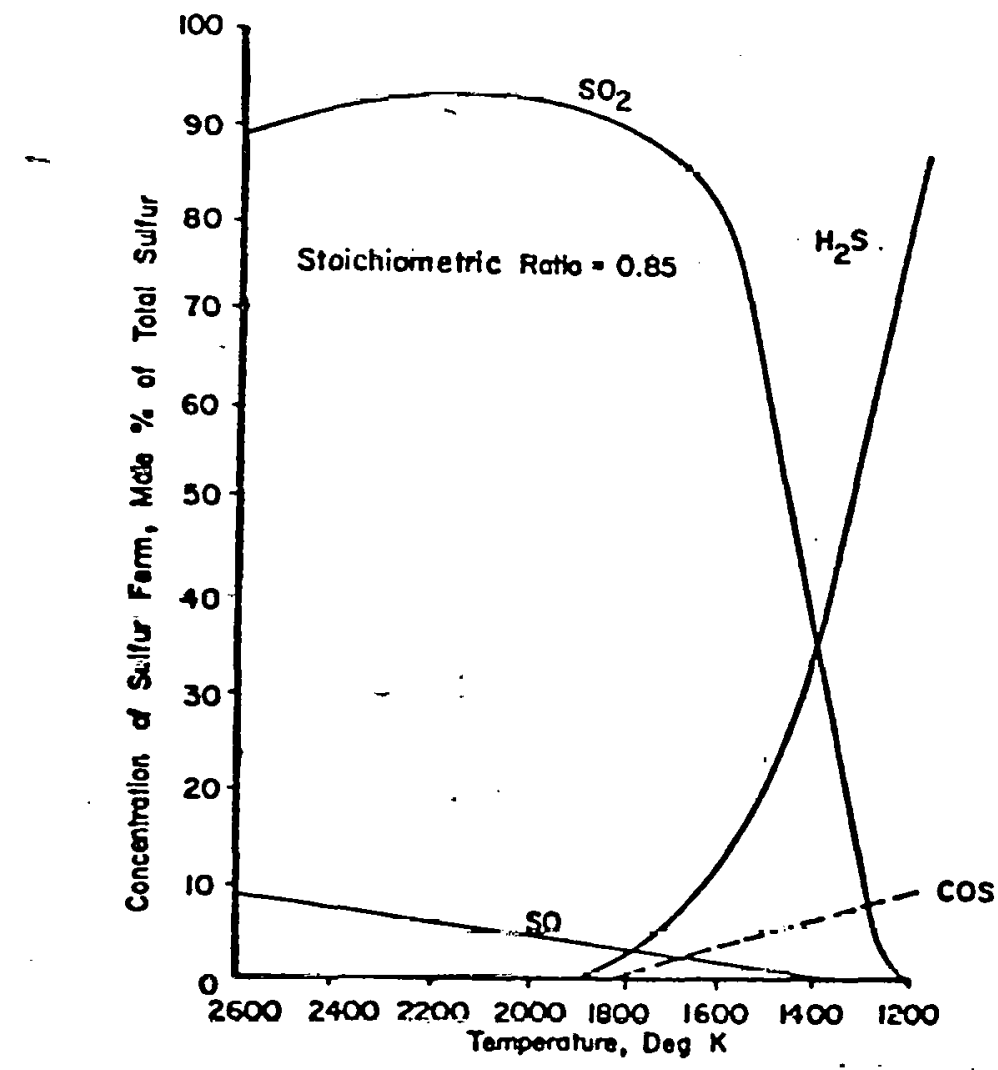

Figure 44. Equilibrium Sulfur Forms at Various Temperatures 15

gas temperatures at the inlet to the radiant furnace and the inlet to the secondary combustor are expected to be about $2422 \mathrm{~K}\left(3900^{\circ} \mathrm{F}\right)$ and $1366 \mathrm{~K}$ $\left(2000^{\circ} \mathrm{F}\right)$, respectively. Thus, $\mathrm{SO}_{2}$ will be the predullital sulfur form in the bulk gas in the reducing part of the boiler. This would likely not be the case inside wall deposits, due to lower temperatures and longer residence times for reduction reactions. Temperatures at the inlet to the Cell III secondary combustor are in the range of 1100-1200K, at which practically all of the $\mathrm{SO}_{2}$ has been reduced to $\mathrm{H}_{2} \mathrm{~S}$ by. the following reaction: 16

$$
\mathrm{SO}_{2}+2 \mathrm{CO}+\mathrm{H}_{2} \rightarrow \mathrm{H}_{2} \mathrm{~S}+2 \mathrm{CO}_{2}
$$


Thus, $\mathrm{H}_{2} \mathrm{~S}$ in the boller tube deposit may attack the metal surface according to the reaction,

$$
\mathrm{H}_{2} \mathrm{~S}+\mathrm{Fe}+\mathrm{FeS}+\mathrm{H}_{2} \text {, }
$$

forming a sulfide scale. Some iron oxides may also be formed due to reaction with $\mathrm{CO}_{2}$ according to the reactions

$$
\begin{aligned}
& \mathrm{Fe}+\mathrm{CO}_{2} \rightarrow \mathrm{FeO}+\mathrm{CO} \\
& 3 \mathrm{FeO}+\mathrm{CO}_{2}+\mathrm{Fe}_{3} \mathrm{O}_{4}+\mathrm{CO} \text { or } 3 \mathrm{Fe}+4 \mathrm{CO}_{2} \rightarrow \mathrm{Fe}_{3} \mathrm{O}_{4}+4 \mathrm{CO},
\end{aligned}
$$

depending upon the temperature and concentration of $\mathrm{CO}_{2}$ as shown in Figure 45.17

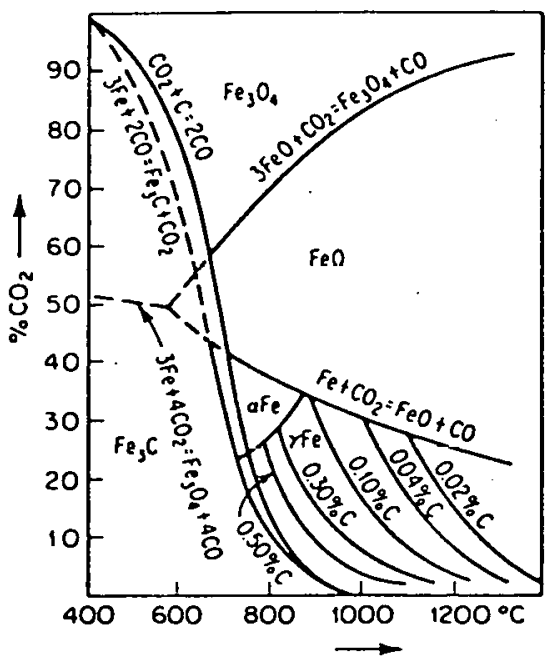

Figure 45. Equilibrium Diagram of the Fe-CO-CO System $^{17}$

The amount of gaseous species available at the metal surface to cause reaction would depend upon the porosity of the overlying deposit and the diffusion rates of these species through the deposit. As was observed, a ronuniform pitting type of attack would be expected due to the varying concentration of gases over the surface.

The compounds which cause most of the damage to tubes in conventional toilers fired with an excess of oxygen are liquid alkali pyrosulfates and solid complex alkali trisulfates, the existance of which are dependent upon the presence of significant amounts $(1000-1500 \mathrm{ppm})$ of $\mathrm{SO}_{3}$. With a stoichiometry of 0.85 , this amount of $\mathrm{SO}_{3}$ is very unlikely. Corrosion of conventional boilers has also occurred due to iron sulfide deposits originatirg from incompletely oxidized pyrites in coal. Subsequent oxidation of the pyrites to $\mathrm{FeS}$ and $\mathrm{Fe}_{3} \mathrm{O}_{4}$ releases $\mathrm{SO}_{2}$, which is oxidized to $\mathrm{SO}_{3}$, so that corrosion can occur by the creation of alkali pyrosulfaces and trisulfates. Again, this process is very unlikely in the present case due to the lack of sufficient free oxygen. However, sulfur released from these pyrites inside tube deposits may cause sulfidation of 
the surface. A condition which exists in the operation of the Cell III test facility that would favor the presence of pyrites at the metal surface is the gradual increase in oxygen supplied to the combustor such that very incomplete combustion occurs during the period when the initial layer of surface deposit is formed. This probably accounts for the highly porous, black inner layer observed in the probe deposits.

A liquid phase can occur in mixtures of $\mathrm{KOH}$ and $\mathrm{K}_{2} \mathrm{CO}_{3}$ at temperatures as low as $640 \mathrm{~K}\left(693^{\circ} \mathrm{F}\right)$, which would flux sulfide and oxide scales, resulting in increased corrosion rates. However, no evidence of liquid phases was seen in the inner portion of the boiler corrosion probe deposits. From Figure 8 it is obvious that a liquid was at the metal surface during one or all of TP41-OL, I'P41-OL and the kerosene shakedown run. The total time on coal was only about two minutco at thic point. The deposited material had the appearance of oily soot and may have been kerosene residue. Sulfidation of the surface was already very much evident by the black color and pitting.

Considerable variation existed in the appearance of the boiler probe deposits from run to run. Some of this, as noted previously, is accounted for by the extent of hydration that had been allowed to occur prior to removal of the probe. Some, however, cannot be related to this. In all runs except 3 and 13, the outer surface of the deposit was liquid as indicated by the drops and streams formed. This is probably related to the thickness of the deposit. In run TP41-03, the deposit was thinner than in later runs. In run TP41-13 the front deposit was as much as about $3.18 \mathrm{~mm}$, which is as thick as most of the deposits on earlier runs. Addition of calcium oxide may account for the change 1n the fusion cemperature of the deposit.

\section{B. SUPERHEATER CORROSION}

Tests under superheater conditions have shown that cementious deposits, as much as $3.18 \mathrm{~mm}$ ( 0.125 inch) thick, may be built upon the front surface of tubes. These deposits on the probe were crusty and hard on the outside, sut not wcll adhered to the tube since the bulk doposit was separated from the tube wall by a thin white powdery layer. Drops and streams of material showed that a liquid has existed at the outer surface. There was no evidence, however, that liquids had existed adjacent to the tube surface.

A scale was found on the metal surface, its thickness depending upon the alloy. In general, the scaling resistance of the alloys appeared to be directly related to the chromium content, with Type 310 stainless steel being the least affected of the materials tested. It seems evident that none of the low or intermediate alloy steels are sufficiently resistant to scaling.

The composition of the scale has not yet been determined. The front scale varied from black to brown, being very nonuniform and mottled. The back scale on the carbon steel sample was a mixture of red and black while that on the Croloy samples was almost entirely red. The middle stainless spacer had a mixture of black and red at the back and was significantly more attacked than Spacer 3 at the cool end of the probe. The back of the 
stainless samples showed a mixture of red and black scale that was very thin and discontinuous, much of the surface having the characteristic tint of chromic oxide. It appears likely that the red scale is $\mathrm{Fe}_{2} \mathrm{O}_{3}$. The dark scale on the front of the samples is probably predominantly $\mathrm{FeO}, \mathrm{Fe}_{3} \mathrm{O}_{4}$ or a mixture of the two and was formed under thick deposits where insufficient oxygen was present for forming appreciable amounts of the higher oxide. Some $\mathrm{Fe}_{2} \mathrm{O}_{3}$, however, was indicated in all areas.

Chemical analysis of the probe deposit showed it to be about $81 \%$ $\mathrm{K}_{2} \mathrm{SO}_{4}$, 5.5\% $\mathrm{K}_{2} \mathrm{CO}_{3}$, 5.6\% miscellaneous oxides and about $8 \%$ unidentified. The most likely corrosion modes are considered to be gaseous oxidation and attack by, or the formation of, solid potassium iron trisulfate $\left(\mathrm{K}_{3} \mathrm{Fe}\left(\mathrm{SO}_{4}\right)_{3}\right.$ according to

$$
3 \mathrm{~K}_{2} \mathrm{SO}_{4}+\mathrm{Fe}_{2} \mathrm{O}_{3}+3 \mathrm{SO}_{3} \rightarrow 2 \mathrm{~K}_{3} \mathrm{Fe}\left(\mathrm{SO}_{4}\right)_{3}
$$

and

$$
\begin{array}{r}
3 \mathrm{Fe}(\text { Tube metal })+\mathrm{SO}_{4}^{-2}(\text { Complex sulfate })+\mathrm{Fe}_{3} \mathrm{O}_{4}+\mathrm{s}^{-2} \\
\text { C. FUTURE TESTING }
\end{array}
$$

\section{FUTURE TESTING}

More run time under both reducing and oxidizing conditions is needed to better assess the severity of the corrosive attack and more extensive analysis by both chemical and $x$-ray diffraction methods is needed to better understand the nature and mechanisms of corrosion.

Continued exposure of the same samples is planned during mid-1980. In addition, samples of carbon and stainless steel aluminized by both pack cementation and slurry methods are planned for inclusion in the probe assembly.

\section{CONCLUSIONS AND SUMMARY}

Initial results of corrosion testing in UTSI's Cell III MHD flow train indicate that corrosion processes are occurring via similar mechanisms as reported in the technical 1iterature. Exposure time in these experiments to date has been very brief. Therefore, these results are of a preliminary nature.

Probe tests simulating IMHD boiler and superheater tube conditions have indicated rapid rates of corrosive attack beneath solid deposits consisting primarily of potassium seed compounds. Corrosion of the carbon steel boiler probe samples was in the form of extensive pitting and the formation of a black sulfide scale, attributed to $\mathrm{H}_{2} \mathrm{~S}$ sulfidation. Superheater probe samples of carbon, low chromium and stainless steel alloys produced varying degrees of scaling depending upon the chromium content. The scales appear to be primarily mixtures of iron oxides and are attributed to oxidation by gaseous constituents and perhaps to the presence of complex potassium trisulfates.

Additional exposure time and analysis of corrosion by-products and deposit constituents are planned, to better define the rates, modes and mechanisms of attack. 


\section{REFERENCES}

1. Chemistry of Coal Utilization, Supplementary Volume, Ed. H. H. Lowry, John Wiley and Sons, Inc. New York, 1963, p. 884.

2. Reid, William T., External Corrosion and Deposits - Boilers and Gas Turbines, Amer. Elsevier Pub. Co., N. Y. 1971, p. 124.

3. Open-Cycle Magnetohydrodynamic Electrical Power Generation, Ld M. Pelilek aild B. YA. Glrumyatsky, Argonne National Laboratory, Argenne, I11., 1978, p. 571 .

4. Ibid., p. 469.

5. Steam/Its Generation and Use, 39th ed., The Babcock and Wilcox Co., New York, N. Y., 1978, p. 15.20.

6. Ibid.

7. Open-Cycle Magnetohydrodynamic Electrical Power Generation, Ed. M. Petrick and B. YA. Shumyatsky, Argonne National Laboratory, Argonne, I11., 1978, p. 469.

8. Bienstock, D., Demski, R. S., and Corey, R. C., "Corrosion of HeatExchange Tubes in a Simulated Coal-Fired MHD System," J. of Engrg. Power, 1971, Vol. A-93, No. 2, pp. 249-256.

9. Open Cycle MHD Powor Generation, Ed. J. B. Heywnod and f. I. Wnmack, Pegramon Press Ltd, London, 1969, pp. 716-721.

10. Ibid., p. 158 .

11. Hals, F. A., et al. "Studies of Seed Recovery and Corrosion in Coal-Fired MHD Power Plants," ASME Paper 64-WA/Ener-5.

12. Cuthil1, J. R. and Kahan, D. J., "Material Assessment," Development Testing and Evaluation of MHD-Materials, Quarterly reports for the period January 1977 - Suptember 1978 for Contrart. No. E(49-1) -3800 . National Bureau of Standards, Washington, DC.

13. First International Conf. on Materials for Coal Conversion and Utilization, (Abstract) October 11-13, 1977, Gaithersburg, MD., Conf. 771025 UC-90h, NTIS, Depr. of Commerce, 5285 Purt Royal Rd., Springfield, VA 22161.

i4. Singh, R. N., Natesan, K., Mailhiot, R. E., el al., "MHD Heat and Seed Recovery Technology Project," Quarterly reports for the period January 1978 - June 1979 for DOE Contract No. W-31-109-Eng-38, Argonne National Laboratory, Argonne, Ill. 
15. Lanier, J. H., Attig, R. C., Kulesza, P. R., "Sulfur Dioxide and Nitrogen Oxide Emissions Control in a Coal-Fired Magnetohydrodynamics System," Presented at the 1979 ASME Winter Annual Meeting, December 2-10, 1979, New York, NY, P. 3.

16. Barnhart, D. H., and Dieh1, E. K., "Control of Nitrogen Oxides in Boiler Flue Gases by Two-Stage Combustion," Babcock and Wilcox Company, presented at 52nd Annual APCA, June 1959, Los Angeles, CA.

17. Jones, W. D., "Fundamental Principles of Powder Metallurgy," Edward Arnold (Publishers) Ltd., London, 1960, p. 537. 